Florida International University FIU Digital Commons

7-10-2008

\title{
The Rise of Islamism Among Turkish Immigrants in Germany and the Netherlands
}

Gönül Tol

Florida International University, gonultol@gmail.com

DOI: $10.25148 /$ etd.FI10022551

Follow this and additional works at: https://digitalcommons.fiu.edu/etd

\section{Recommended Citation}

Tol, Gönül, "The Rise of Islamism Among Turkish Immigrants in Germany and the Netherlands" (2008). FIU Electronic Theses and Dissertations. 218.

https://digitalcommons.fiu.edu/etd/218

This work is brought to you for free and open access by the University Graduate School at FIU Digital Commons. It has been accepted for inclusion in FIU Electronic Theses and Dissertations by an authorized administrator of FIU Digital Commons. For more information, please contact dcc@fiu.edu. 


\section{FLORIDA INTERNATIONAL UNIVERSITY}

Miami, Florida

THE RISE OF ISLAMISM AMONG TURKISH IMMIGRANTS IN GERMANY AND THE NETHERLANDS

A dissertation submitted in partial fulfillment of the

requirements for the degree of

DOCTOR OF PHILOSOPHY

in

POLITICAL SCIENCE

by

Gönül Tol

2008 
To: Dean Kenneth Furton

College of Arts and Sciences

This dissertation, written by Gönül Tol, and entitled The Rise of Islamism among Turkish Immigrants in Germany and the Netherlands, having been approved in respect to style and intellectual content, is referred to you for judgment.

We have read this dissertation and recommend that it be approved.

$\begin{array}{r}\text { Aisha Musa } \\ \hline \text { Tatiana Kostadinova } \\ \hline \text { Nicol Rae } \\ \hline \text { John F. Stack, Jr., Major Professor }\end{array}$

Date of Defense: July 10, 2008

The dissertation of Gönül Tol is approved.

Dean Kenneth Furton
College of Arts and Sciences

Florida International University, 2008 
CC Copyright 2008 by Gönül Tol

All rights reserved. 


\section{DEDICATION}

To my parents, Emine and Veli TOL, for all those sunny Sundays and sleepless nights that were spent on the orange field... 


\section{ACKNOWLEDGMENTS}

Writing a dissertation is a journey that you make to discover the story of others but at the end you discover more about your own self. I would like to thank everybody who has joined me in this 7 year journey to the world outside and my own self.

I am grateful to my chair, Dr. John F. Stack, Jr. who has not only been a mentor and an inspiration but also a good friend who has always believed in me. He equipped me with the knowledge that I needed and let me make my own story. He shared my passion and enthusiasm. Without his guidance and continuous support, this study would not have been completed. I thank Dr. Tatiana Kostadinova for taking the time to go over the methodology chapters page by page and providing me with valuable feedback and the rest of my committee members Dr. Aisha Musa and Dr. Nicol Rae for their time and support. I would also like to thank Dr. Paul Mullen and Dr. Rebecca Mae Salokar for their continuous encouragement and support throughout my graduate education and Dr. Ronald Cox for always understanding what was not said.

I thank the Jack D. Gordon Institute for Public Policy and Citizenship Studies, Miami European Union Center and the Department of Political Science for supporting my fieldwork to Germany and the Netherlands.

I am mostly grateful to my family. I give special thanks to my sister Gökçe Tol who taught me that home was where you made it. I thank my parents, Emine and Veli Tol, for the life they dedicated to their children, my brother Alper Tol for never leaving my side, my sister in law Didem Tol for her love and compassion, my niece Didesu Tol for the bliss that came with her arrival. I thank Yasemin Akbaba and Antonello Loddo for being a home to me on this side of the ocean. 
I am grateful to my friends without whom life would not be complete. I thank Seyhan Tağıl, Onyeka Ezenwoye, Zuhal Öztürk, Arda Yılmaz, Isa and Esra Afacan, Serhat Sapmaz, and Canan Yildız for the love, joy and happiness they have brought into my life. I also thank my friends at the Jack D. Gordon Institute: Carolina Farfan, Jose Cervantes, Hector Cadavid, Pedro Carvalho, David Twigg and Kenneth Ray. It has been your presence and love that has given me the strength to continue.

Last, but not least, I would like to acknowledge the friends that I made in Germany and the Netherlands during my fieldwork. I thank Dr. Ismail Altıntaş and his family, Murat Altuğlu, Nermin Altuğlu, Metin and Nejla Türköz, Haldun Saatçi, Perihan Reil, Orçun, Sami and Gönül Kazancı, Figen Sen Bakker, Maurice Bakker, Ismet Yürek and his family, Metin and Insaf Gür and Zehra Ulus who not only opened their homes but also their lives to me.

I thank the Milli Gorus community in Germany and the Netherlands. I give special thanks to Canan Uyar, the chairperson of the North Holland Milli Gorus Women's Federation, Mehmet Yaramış, chairperson of the South Holland Milli Gorus for their time and help in distributing the surveys. I thank all Milli Gorus members whose names cannot be revealed here for unselfishly sharing their time, energy and testimonies. No names are given but none are forgotten. Your stories will always be with me... 
ABSTRACT OF THE DISSERTATION

THE RISE OF ISLAMISM AMONG TURKISH IMMIGRANTS IN GERMANY

AND THE NETHERLANDS

by

Gönül Tol

Florida International University, 2008

Miami, Florida

Professor John F. Stack, Jr., Major Professor

This study is a comparative study of the Turkish Islamist movement Milli Görüş (IGMG) in Germany and the Netherlands. It is a qualitative and a quantitative inquiry about the nature (whether it is moderate or radical) of the Milli Görüş movement in these two countries. The central research questions are: what is the reason for the rise of Islamism among Turks living in two different countries in Europe? What is the reason for the difference in the radicalization levels?

Islamism refers to an ideology that turns traditional Islam into a sustained and systematic program that includes social, political, and economic affairs (Pipes 1998). The movements within the framework of Islamism range from moderate to radical. Based on the data collected during the field research conducted in Germany and the Netherlands between the years of 2004-2007, this study suggests that Islamism is a response to social marginalization which is defined as "an external social position, of isolation of the individual or groups, with a limited access to economical, political, educational and communicational resources of the community (Contained in the law adopted by the Romanian Parliament in 28 February 2002, www.hurriyetim.com, November 25, 2004). 
It is hypothesized that as the level of social marginalization increases, so does the level of radicalization. 


\section{TABLE OF CONTENTS}

CHAPTER

PAGE

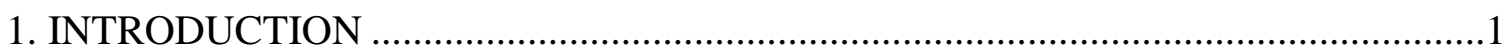

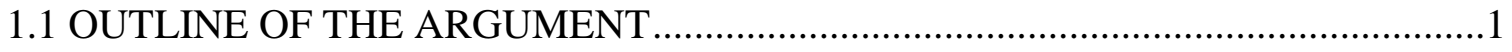

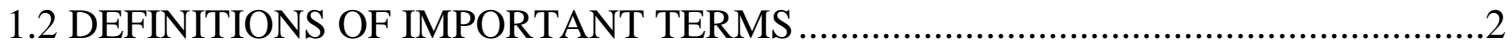

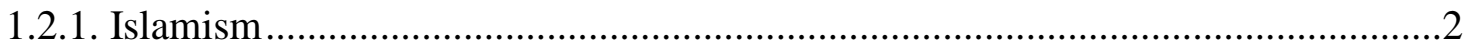

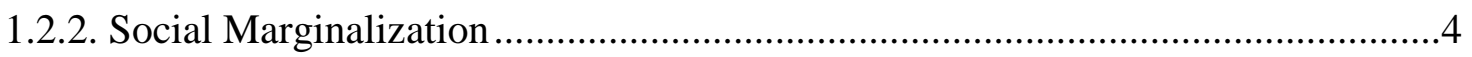

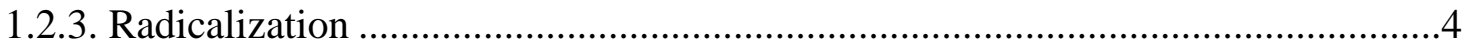

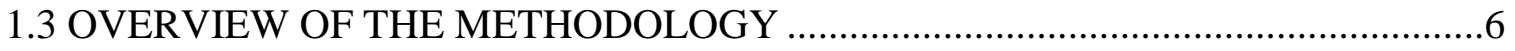

1.4 SIGNIFICANCE OF THE STUDY .................................................................

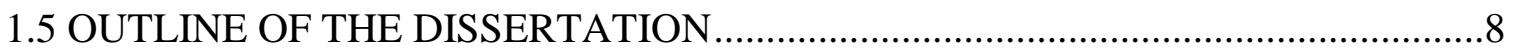

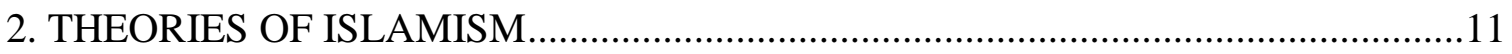

2.1 APPROACHES TO UNDERSTANDING IDENTITY ...........................................11

2.1.1 The Centrality of Religious Identity .............................................................12

2.2 THE LITERATURE ON ISLAMISM: ORIENTALISTS vs. ANTI-

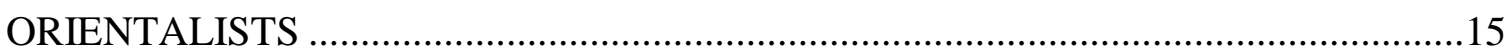

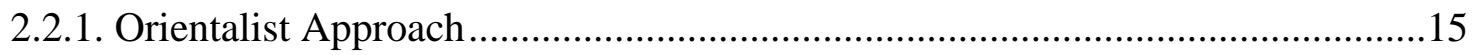

2.2.2. Anti-Orientalist Approach .......................................................................

2.3 THE CHANGING ROLE OF ISLAM WITHIN THE ISLAMIST DISCOURSE:

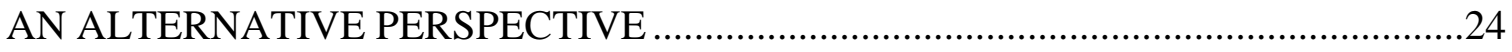

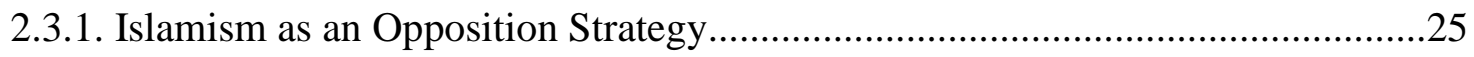

2.3.1.1 Islam as a Master Signifier ......................................................................26

2.3.2. Islamism as a Democratic Participation Strategy ……......................................28

2.3.2.1. Islam as a Religio-cultural Signifier ......................................................29

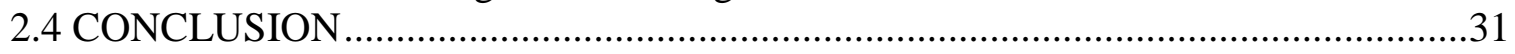

3. SYSTEMIC PROPERTIES OF GERMANY AND THE NETHERLANDS:

LAWS, RULES AND REGULATIONS THAT AFFECT THE IMMIGRATION

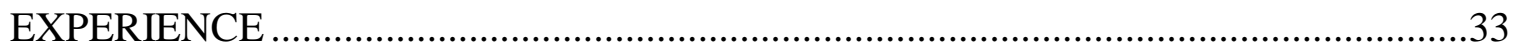

3.1 FROM MIGRANT LABOR TO ETHNIC MINORITY: THE TURKS IN

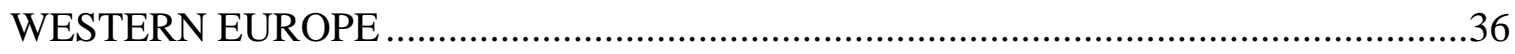

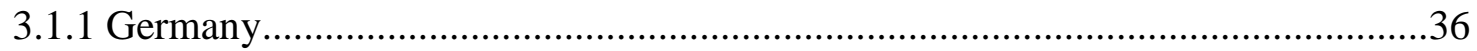

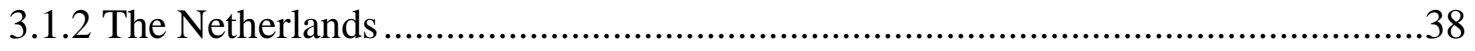

3.2 LEGAL, ECONOMIC AND SOCIAL STATUS OF TURKS IN GERMANY

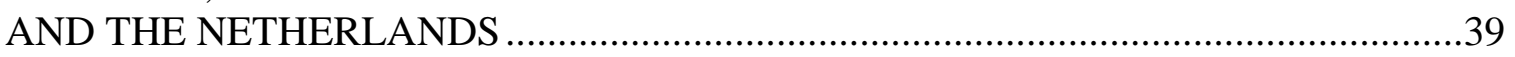

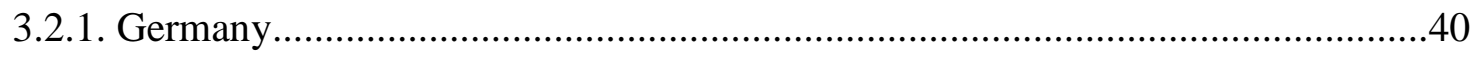

3.2.1.1. The Continuity of Jus Sanguinis: Understanding It within the Historical

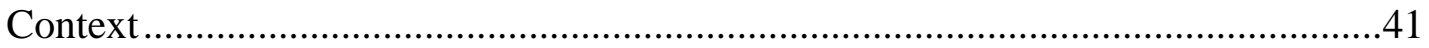

3.2.1.2. Legal Definition of Immigrant ..................................................................4

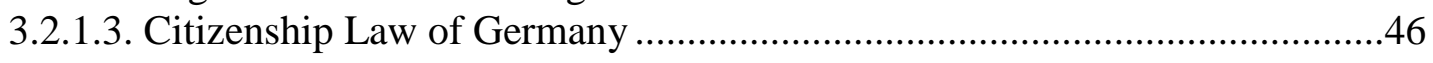

3.2.1.4. Political Rights of Foreigners ...................................................................48 
3.2.1.5. Economic Status of Turkish Immigrants: From Guest Workers to

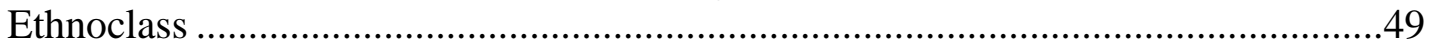

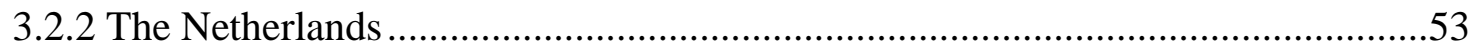

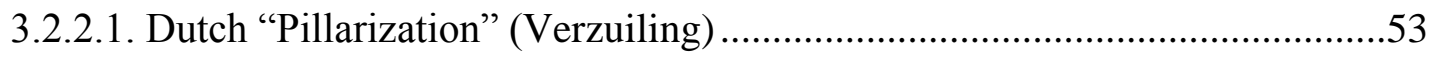

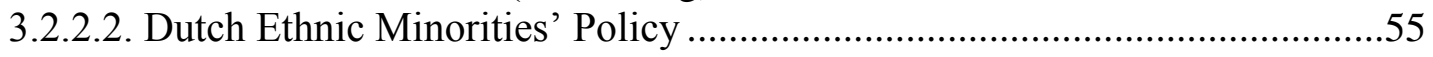

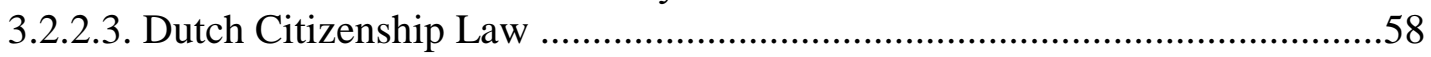

3.2.2.4 Economic Status of Turks in the Netherlands.............................................61

3.3 INSTITUTIONALIZATION OF ISLAM IN GERMANY AND THE

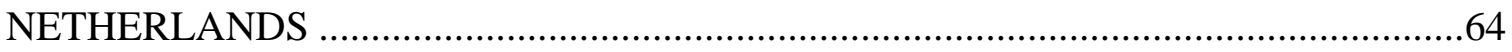

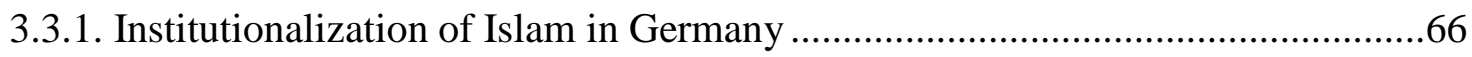

3.3.1.1. Non-Governmental Islamic Organizations in Germany ............................68

3.3.1.2. Turkey as Administrator of Islam in Germany ....................................... 70

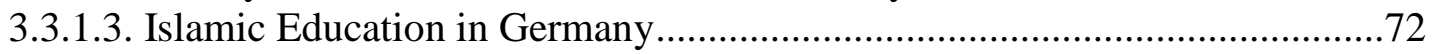

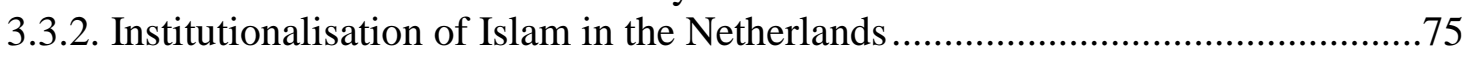

3.3.2.1. Non-Governmental Islamic Organizations in the Netherlands .....................77

3.3.2.2. Turkey as Administrator of Islam in the Netherlands................................ 80

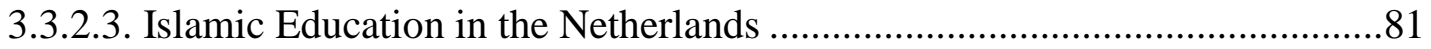

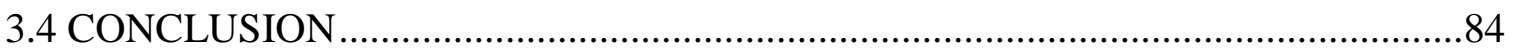

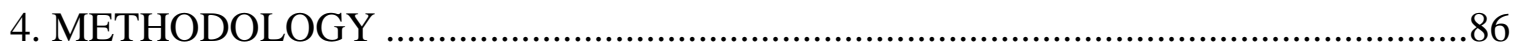

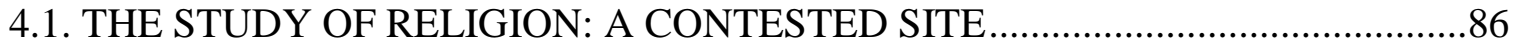

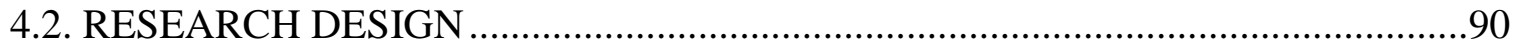

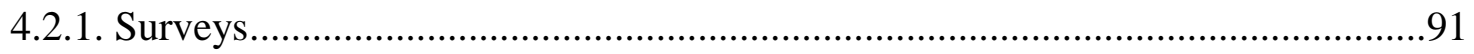

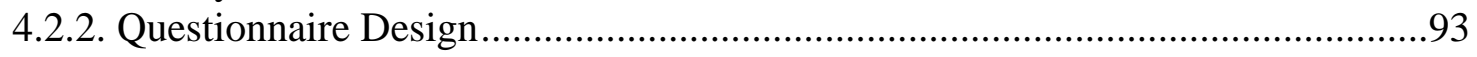

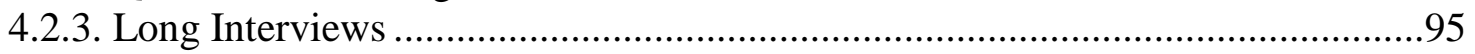

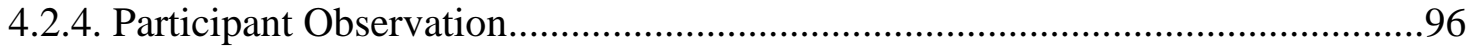

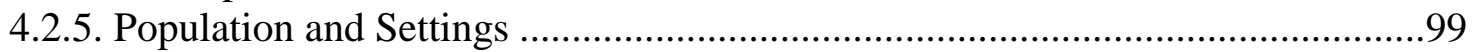

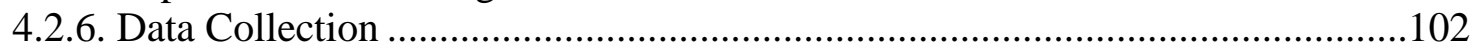

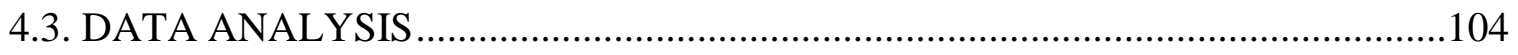

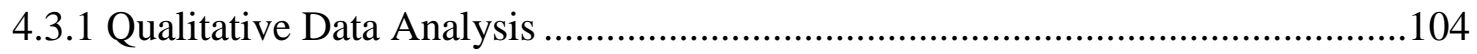

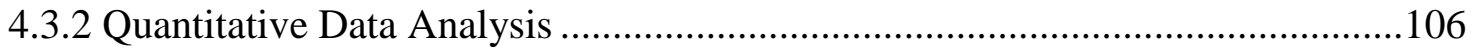

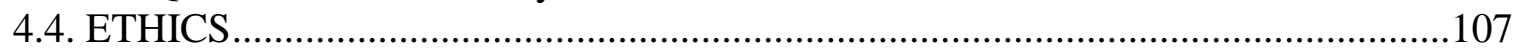

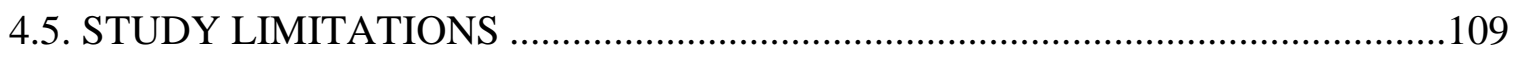

5. IGMG IN GERMANY AND THE NETHERLANDS: ORGANISATIONAL

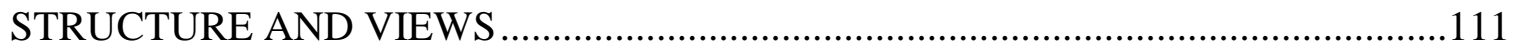

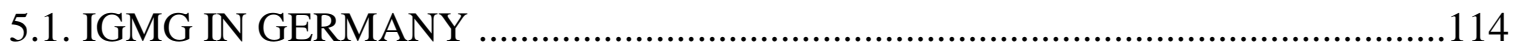

5.1.1. Historical Development of IGMG in Germany .........................................114

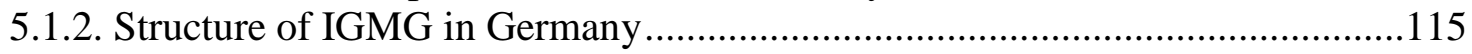

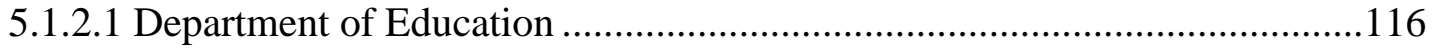

5.1.2.2 Irshad (Religious Guidance) Department ............................................. 117

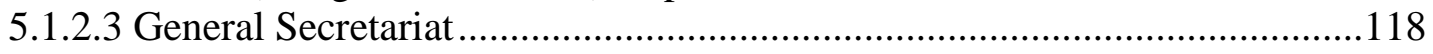

5.1.2.4 Department of Organisational Development ........................................118

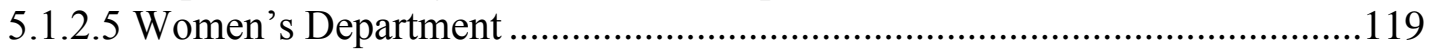

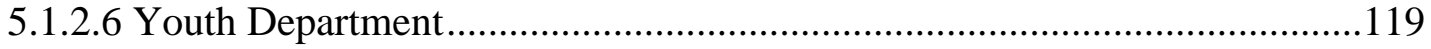


5.1.3. Views of IGMG in Germany ...............................................................122

5.1.3.1 IGMG and German Society: A Relationship Dominated By Distrust and

Skepticism

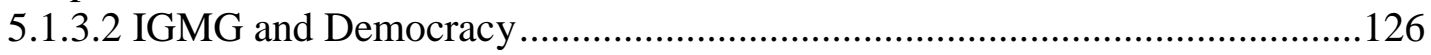

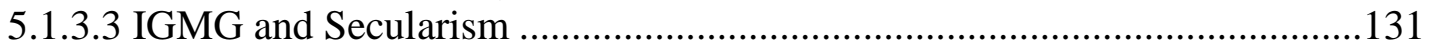

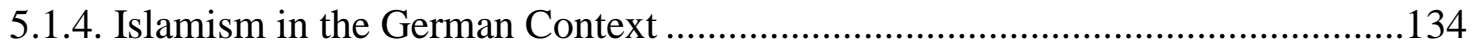

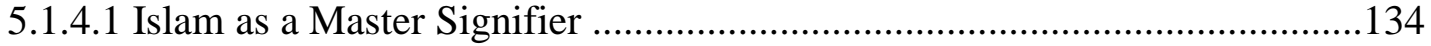

5.1.4.2 Islamism as an Opposition Strategy .......................................................135

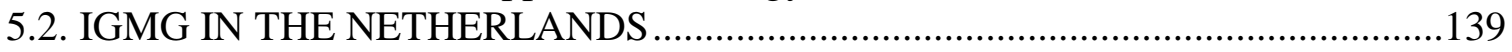

5.2.1. Historical Development of IGMG in the Netherlands ..................................139

5.2.2. Structure of IGMG in the Netherlands ....................................................... 140

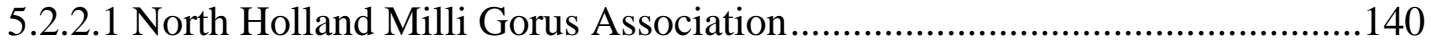

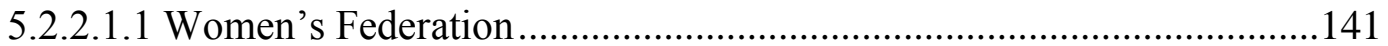

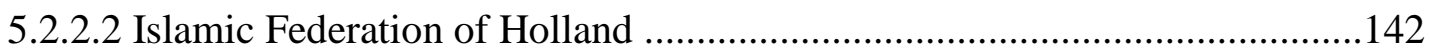

5.2.3. Views of IGMG in the Netherlands ............................................................. 143

5.2.3.1 IGMG and the Dutch Society: A State of Peaceful Coexistence .................143

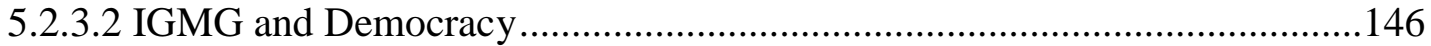

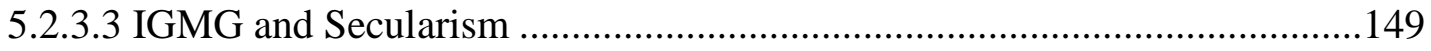

5.2.4. Islamism in the Dutch Context ................................................................... 151

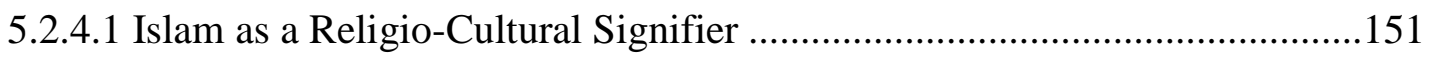

5.2.4.2 Islamism as a Democratic Participation Strategy .....................................155

5.3. EXPLAINING THE DIFFERENCE: A CONTEXTUAL ARGUMENT ................158

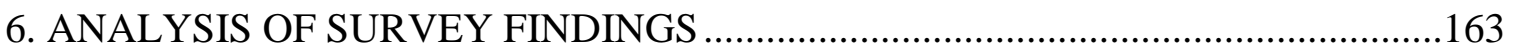

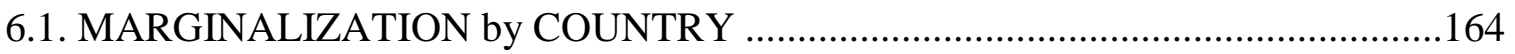

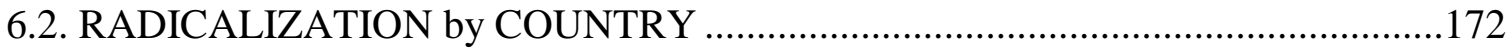

6.3. TOTAL MARGINALIZATION AND TOTAL RADICALIZATION ....................183

6.4. CORRELATION BETWEEN TOTAL MARGINALIZATION AND TOTAL

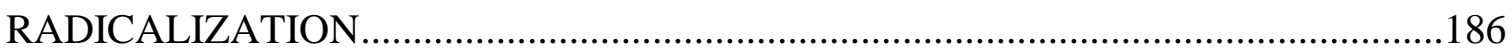

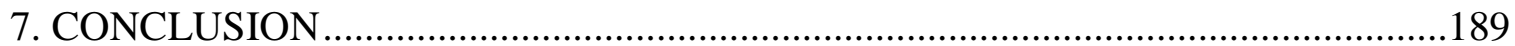

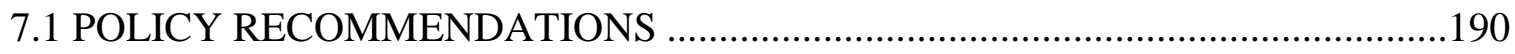

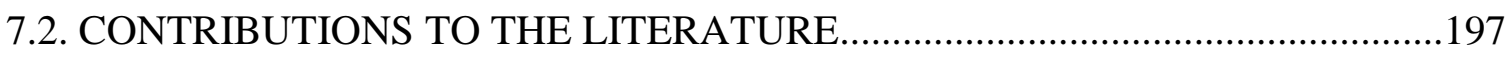

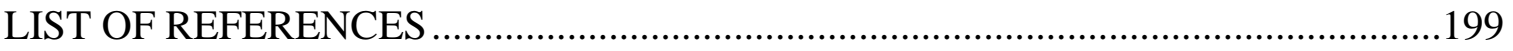

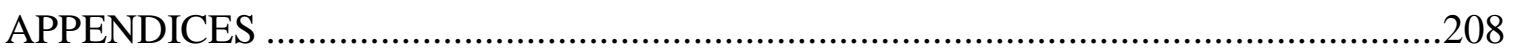

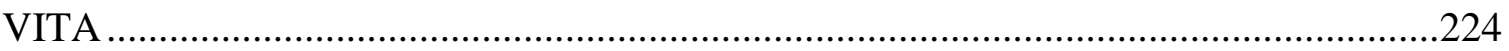




\section{LIST OF TABLES}

TABLE

PAGE

Table 6. 1 Group Statistics of Marginalization for Germany and the Netherlands .......... 165

Table 6. 2 Independent Samples Test of Marginalization ......................................... 173

Table 6. 3 Group Statistics of Radicalization for Germany and the Netherlands............. 174

Table 6. 4 Independent Samples Test of Radicalization........................................... 185

Table 6. 5 Regression Results ............................................................................. 188 


\section{LIST OF FIGURES}

FIGURE

PAGE

Figure 4. 1 Idealized distributions for treated and comparison group posttest values.... 106

Figure 4. 2 Three scenarios for differences between means ...................................... 107

Figure 6. 1 Total Cultural Marginalization Indicators ............................................ 166

Figure 6. 2 Total Economic Marginalization Indicators ........................................ 168

Figure 6. 3 Total Political Marginalization Indicators ............................................ 169

Figure 6. 4 Total Social Marginalization Indicators .............................................. 170

Figure 6. 5 Total Anti-democracy Attitudes ........................................................ 175

Figure 6. 6 Total Anti-tolerance Attitudes ...................................................... 176

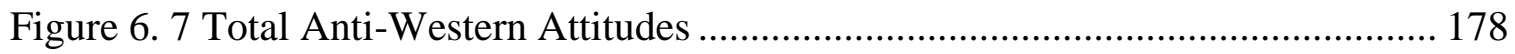

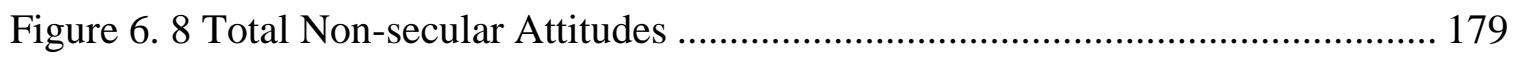

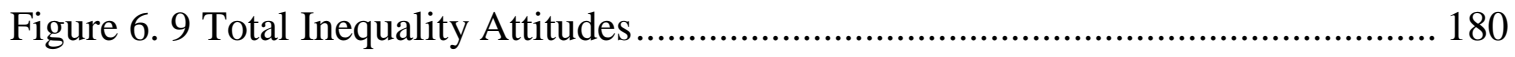

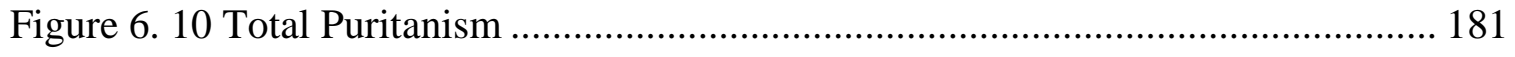

Figure 6. 11 Total Monoethnicism Attitudes ........................................................ 182

Figure 6. 12 Total Anti-integrationist Attitudes ................................................ 183

Figure 6. 13 Total Marginalization Indicators ..................................................... 184

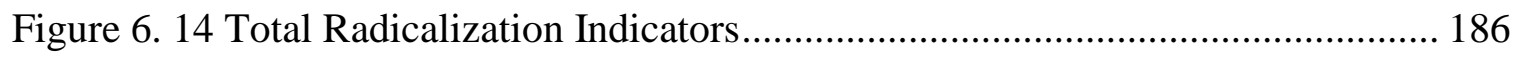

Figure 6. 15 Correlation between Total Radicalization and Total Marginalization ....... 187 


\section{CHAPTER 1}

\section{INTRODUCTION}

\subsection{OUTLINE OF THE ARGUMENT}

This is a comparative study of the Islamist movement among Turks residing in Germany and the Netherlands. Islamism refers to an ideology that turns traditional Islam into a sustained and systematic program that includes political, social and economic affairs (Pipes 1998).It is a qualitative and a quantitative inquiry about the nature (whether it is moderate or radical) of the dominant Turkish Islamist movement Milli Gorus (IGMG) in these two countries.

While Milli Gorus in Germany is an Islamist movement that has a strong antiWestern rhetoric and treated as an "Islamist extremist group" by the German Federal Ministry of the Interior (2005), Milli Gorus in the Netherlands cooperates with the local Dutch authorities on establishing programs that aim to further integrate the Muslim community into the Dutch society. While Milli Gorus in Germany has a radical outlook on Western institutions in general and German society in particular, Milli Gorus in the Netherlands is quite moderate and is considered as a legitimate actor in the Dutch public space. The central research question is: what is the reason for this difference? Why did an Islamist group that started as the European extension of the same Islamist movement at the end of the 1960s become a government identified Islamist extremist group in Germany while it turned into a democratic partner in promoting integration of Muslims into Dutch society in the Netherlands? It is hypothesized that social marginalization leads to radicalization of Islamist movements. 
Despite the general tendency within the literature on Islamism to label all Islamist associations as being undemocratic due to a shared Islamic ethos, this study suggests that Islamist groups vary in ideology and methods from one another. They can become a counter-hegemonic force by formulating an oppositional discourse towards the status quo and threaten the institutional structure. They can also be a potential force for democratization of the Islamic community by generating a political discourse that is couched in the language of democracy. The role Islamist associations play in society is determined by the role of Islam within the Islamist discourse which is shaped by the social, economic and political structure within which Islamists operate.

Islam is treated in this study both as a societal agent and as a language. Islamism is not an irrational psycho-social regression. It is a rational and realistic response to the logic of social marginalization. Islamists are social players who seek to establish themselves meaningfully within a modern society, which is ruled by a dynamic that forces them out to the periphery economically, politically and socially. Islamist discourse shapes and is shaped by the social reality. Islamism is a new cultural discontinuity among Muslim minorities in Western Europe. This study clarifies Islamism's ability to contribute to the identity formation of Muslim minorities in Europe and also evaluate Islamism's alternative and potential to formulate an opposition strategy.

\subsection{DEFINITIONS OF IMPORTANT TERMS}

\subsubsection{Islamism}

Although there is not a consensus in the literature about the content of the term political Islam, the term Islamism will be used in this study instead of fundamentalism. There are three terms which are often used to refer to the term political Islam: 
traditionalism, fundamentalism, and Islamism. While Islamism can be formulated on the basis of being a critique of traditionalism, fundamentalism might be argued to constitute the foundations of Islamism. Islamism differs from traditionalism in stressing the sociopolitical dimension of the religious framework, while fundamentalism is a reiteration of the authenticity of the holy scripture. Therefore, the Islamists can be said to be fundamentalists but the reverse does not necessarily follow (Pedersen 1999). The use of the term Islamism is an attempt to coin a term that covers: 1) a variety of institutional forms (they can be local, transnational, or international) 2) very different political forms, ranging from underground organizations whose activities are banned by the host state to the organizations/movements that are considered essential for the adjustment of Turkish immigrants in the host countries 3) very different methods of action, ranging from encouraging conversion from within the mosques to more radical social and political mobilization including violent action (Pedersen 1999). The movements within the framework of Islamism range from moderate to radical. Islamism can range from the assertion of a Muslim subjectivity to an attempt to reconstruct society on Islamic principles (Sayyid 2003). This study suggests that radical Islamism is a response to social marginalization. It is not a medieval program whose main framework can be found in the holy texts but one that responds to the strains of the twenty first century. Islamism is a constructed religious identity which finds its breeding ground in the modern Western context. It offers a modern religious identity that is a collective answer to the forces of marginalization and is capable of coping with the challenges of modern life (Pedersen 1999). 


\subsubsection{Social Marginalization}

Social marginalization is defined as "an external social position, of isolation of the individual or groups, with a limited access to economical, political, educational and communicational resources of the community" (The law adopted by the Romanian Parliament in 28 February 2002, www.hurriyetim.com, November 25, 2004). The literature lacks an inclusive definition of social marginalization. The definition adopted by the Romanian Parliament includes economic, political and social aspects. Therefore this definition is used in this study.

The social marginalization processes that characterize the situation of the Muslim immigrants in Europe leave these groups of population without a positive social identity (Pedersen 1999). The Islamic movements offer an alternative social context in which it is not the marginalized social processes which ascribe the significance of social identity. A Muslim cultural identification that includes the creation of a specific Islamic identity manifested in the shape of Islamism in Western European modernity is constructed (Vertovec \& Peach 1997, Halliday 1996).

\subsubsection{Radicalization}

The term "radical" is used in a variety of contexts but according to the definition in the dictionary it refers to "going to the root, fundamentally or drastically deep" (Slootman \& Tillie 2006: 17). The concept is defined similarly by the General Intelligence and Security Service of the Netherlands (Algemene Inlichtingen-en Veiligheidsdienst, AIVD):

The (actively) pursuing and/or supporting deeply fundamental changes in society, which could become a danger for (the continuation of) democratic rule of law 
(goal), possibly through use of undemocratic methods (means), which could impair the functioning of the democratic rule of law (effect). By extension, radicalization can be defined as the (increasing) willingness to pursue or support changes (possibly in an undemocratic manner), or to persuade others to do so. (AIVD 2004 in Slootman \& Tillie 2006: 17).

Slootman and Tillie (2006) also see radicalism as the pursuit of fundamental changes in society but they describe it in terms of legitimacy, which is the definition that is adopted by this study.

The process of radicalization is seen as an increasing loss of legitimacy for the democratic society, where the final form of radicalism (extremism) is seen as the antithesis of democracy. Democracy is based on ideas such as national sovereignty and equality for all citizens, as well as freedom of religion and freedom of expression. Extremism, in contrast, refuses to accept democratic values and principles, and presents its own ideology as the universally valid one which must be forced upon the population, if necessary with violence. It places uniformity against diversity, intolerance against tolerance, and orders against dialogue. Legitimacy of the system is a requirement for democracy. Democracy exists only by the confidence that citizens have in the political system, which depends largely on the citizens' perception of the manner in which basic functions are performed and problems are dealt with. It is not necessary for all citizens to display all democratic values such as diversity, tolerance, dialogue and willingness to make compromises, but at least a large part of the population must 
at least passively support the majority of these values. Radicalization can be seen as a process of denying this support to the system (Slootman \& Tillie 2006: 17).

\subsection{OVERVIEW OF THE METHODOLOGY}

Comparing the German case with the Dutch case provides the opportunity to show how levels of social marginalization determine whether an Islamist organization is radical or moderate. Germany and the Netherlands are picked for comparison based on the most similar system design. Such a design compares similar cases on the assumption that the more similar the cases being compared, the more possible it is to isolate the factors responsible for differences between them (Andrew 1994: 310). Germany and the Netherlands are both Western democracies with similar levels of economic development. They both have Muslim immigrant populations as a result of the labor treaties they signed with the Muslim countries at the beginning of the 1960s. Milli Gorus has been operating within these countries since the 1970s and it constitutes one of the most important Islamist movements among the Turkish immigrant community both in Germany and the Netherlands. They differ in the marginalization level of Milli Gorus. Comparing these two cases makes it possible to isolate the factors responsible for differences in the radicalization level of Milli Gorus.

This study is primarily based on the fieldwork carried out among Islamists in Germany and the Netherlands in the years from 2004-2007. The methodology is based on a number of qualitative techniques including elite interviews supplemented by primary research in the form of legal documents, media coverage, public statements of the leaders of the organization, the written statements of the organization about the objectives of the movement, and statements of the mosque leaders, mutual aid societies and other civic 
organizations, and participant observation and quantitative techniques including surveys. The study draws on socio-economic assessments of the Turkish communities in Germany and the Netherlands provided by local communities and the national governments.

Based on the radicalization and social marginalization definitions provided in the previous section, a survey was designed in order to assess the levels of radicalization and social marginalization among Milli Gorus members. While designing the survey, World Values Survey was utilized extensively. The surveys were distributed to Milli Gorus mosques after Friday sermons and during Milli Gorus gatherings such as weddings, funerals and religious meetings.

\subsection{SIGNIFICANCE OF THE STUDY}

The Islamist movements constitute one of the biggest political challenges facing nation states both in the Middle East and in West Europe. The Muslim world plays a much more important role in shaping and defining Europe in the twenty first century than the United States, Russia, or even the European Union (Savage 2004). Since the Iranian Revolution, the increasingly visible and vocal communities of Muslim migrants and their descendants have become the subject of public concern and reactionary policies throughout Europe (Vertovec \& Peach 1997). Despite the increasing attention given to the Muslim world by academic circles, media, public and policy-makers, the non-Muslim world conceives it in a rather monolithic way. By many scholars, policy makers and different segments of society essentialised images of Islam are taken as a common-sense explanatory factor in world affairs (Vertovec \& Peach 1997).

The cover of the 15 June 1992 issue of the international edition of Time magazine, for instance, displayed a photograph of a minaret in the background. In the 
foreground there was an arm holding a weapon; under the photograph appeared the title: "Islam: Should The World Be Afraid?". The front page of the 20 April 1995 issue of British Daily Today had a picture of a fireman cradling a bloodstained baby under the title of "In the Name of Islam" (Vertovec \& Peach 1997). There are extensive media coverage of this sort after the $9 / 11$ attacks. These attacks not only strengthened the already existing fears and suspicions among the public but these fears and hostility toward Islam and Muslim populations both in Europe and the United States were institutionalized through the formulation and implementation of government policies. Without understanding the real dynamics, Islamic movements have been considered as a natural continuation of Islamic faith and treated accordingly. Therefore the study of Islam and Islamic movements is much more important today both for the public debate and for scholarly concern than it was a decade ago.

\subsection{OUTLINE OF THE DISSERTATION}

This study presents the new trend which the more recent Islamist movements represent among Muslim minorities. Chapter 2 provides a review of the literature on identity and Islamism and focuses on the current divide between the orientalists and the anti-orientalists on the issue of Islamism. It offers an alternative perspective of understanding Islamism by focusing on the changing role Islam plays within the Islamist discourse.

Chapter 3 outlines the systemic properties of Germany and the Netherlands which are hypothesized to produce the different results in the Milli Gorus case. The immigration and citizenship laws of each country are analyzed in order to compare the different 
approaches to immigration and how those approaches shape institutionalization of Islam and determine the place of Muslims in the host country's public space.

Chapter 4 discusses the methodological questions in regards to the study of religious movements, particularly Islamist movements. It outlines the methodological debate in the literature and answers the question of what the best method is to understand the dynamics of Islamist movements.

Chapter 5 focuses on the institutionalization of Milli Gorus in Germany and the Netherlands. The intention is to make clear what kind of perspectives a particular Islamist group offers to the primarily Turkish Muslim minorities in the European context. What type of community the members are offered. What kind of organizational framework is associated with involvement in the movement. It describes the organizations in Germany and the Netherlands and presents the background material for the subsequent analysis of the movements' positions. It then moves on to a description of how the Islamist movements establish a communal space for redefining their cultural heritage. Islamism is similarly sketched at the individual level so as to clarify what crucial life experiences and interpretations are at the heart of joining an Islamist community and what social roles the community plays in relation to the development of social contacts (Pedersen 1999). Throughout Chapter 5, the emphasis given to Milli Gorus in Germany reflects the demographic landscape. In Germany, there are 3.4 million Muslims and 2.4 million of them are of Turkish origin. In the Netherlands, on the other hand, there are 1.1 million Muslims. Besides 328,000 Turkish Muslims, there are 295,000 Moroccans (Central Bureau of Statistics 2005). Therefore, the Turkish Muslim community in Germany is stressed more in the study. 
Chapter 6 summarizes the quantitative findings of the survey results and conducts t-test in order to compare the radicalization and marginalization levels in Germany and the Netherlands.

The study ends with the conclusion in which policy recommendations and contributions to the literature are presented. 


\section{CHAPTER 2}

\section{THEORIES OF ISLAMISM}

Although the main focus of this study is not the process of identity construction, it is important to understand how groups perceive themselves and others and how these perceptions lead to different outcomes in different social and political settings to be able to comprehend the birth, growth and functions of Islamist groups. This chapter presents a brief review of different approaches to understanding identity and a review of literature on Islamism. It outlines the debate between orientalists and anti-orientalists. It then focuses on the changing role of Islam within the Islamist discourse as an alternative perspective to understanding Islamism.

\subsection{APPROACHES TO UNDERSTANDING IDENTITY}

There are different approaches to understanding identity. One line of thought views identity as something that is inherited, something that we remember from the past. On the other hand, there are those scholars who argue that identity is not inherited but something that is told, remembered from the present, not from the past (Benedict Anderson, 1991). Primordialism, which belongs to the first line of thought, argues that the critical features of ethnic identity are based on emotive dimensions that are ascriptive (Stack 1997). Ethnicity is composed of primordial affinities and attachments. Harold Isaacs states "basic group identity consists of the ready-made set of endowments and identifications that every individual shares with others from the moment of birth by the chance of the family into which he is born" (Isaacs 1975, 26-38). Although some scholars of the primordialist school see ethnic identity as genetic links, there are some other approaches that define ethnic identity in cultural terms rather than biological terms. They 
view ethnicity as the similarity of cultural attributes that stem from shared interpretations and expressions of reality (Smith 1986, 21-22).

The instrumentalist approach, on the other hand, views identity and construction of identity as a tool to achieve certain material interests. This approach points to the selfinterested basis of group formation arguing that elites help to define group priorities based on a range of material interests. The members of the group share these interests but the elites have additional interest in formation of these groups because they gain power by leading that pursuit (Kaufman, 2001, 17).

Constructivists, on the other hand, argue that identity is constructed by intellectuals. They assert that identity should not be viewed as static, ancient or inherent in a group's blood nor should it be reduced to a rational means-end calculation by the elites who want to gain economic or political interests (Croucher 1997, 14-15). This study adopts the constructivist approach and argues that identity should be understood as a cultural construction accomplished over time. Groups are recreated in response to the changing contexts. Identity has different components- language, ethnicity, religion, gender, socio-economic class, and region- which one will shape an individual's actions is determined by political and social context. The next section provides an answer to the question of why it is religion that is being used as a tool for social and political mobilization among Turks in Germany and the Netherlands rather than language, ethnicity, or economic status.

\subsubsection{The Centrality of Religious Identity}

While other components of identity formation are the main dividing line among a number of groups- for instance language plays a vital role in the Québec case while 
ethnic identity is the main dividing line between the Turks and the Kurds in Southeast Anatolia- religion carries a moral base which provides a stronger positive identity and increases the legitimacy of the opposition. In the Turkish immigrant case, ethnicity is the main factor that creates grievances and leads to social marginalization which is considered to be the root cause of Islamism. In Germany, it is the non-Germannes or the notion of the 'other' that draws the boundaries between the groups. The initial construction of an 'enemy image' by German society is based on the ethnic division. In the first instance it is the Turkish immigrant group that is the 'other', not the Muslims. But the Turkish immigrant society responds to this division and exclusion by emphasizing the strongest and most efficient component of its identity: Islam. This response transforms the social divisions from an ethnically based confrontation to a religious one. The question is not that of a German versus Turkish one anymore but represents a broader framework: Christians versus Muslims.

Religious identity becomes the main identification among the Turkish immigrants in Germany and the Netherlands. Islam becomes the most valuable tool both as a 'psychological anchor' (Bell, 1975) but also as a tool for claims-making in a modern society. It offers a strong positive identity to its followers. According to Jeffrey Seul (1999) the world's religions answer the individual's need for a sense of locatednesssocially, cosmologically, temporally and metaphysically. Religious meaning systems define the contours of the broadest possible range of relationships- to self; to others near and distant; to the non-human world; to the universe; and to God. No other repositories of cultural meaning have historically offered so much in response to the human need to develop a secure identity. Religious traditions and institutions resist constant change in 
the negotiation of social meaning, thus affording individuals and groups more secure anchors for self-reference (Mol 1976). Religion in general tends to promote the stabilization of individual and group identity by favoring the preservation of the old content ( in the form of doctrine, ritual, moral frameworks, role expectations, symbols and the like), offering individuals a basis for reconstructing their identities within a stable or very slowly changing universe of shared meaning (Seul, 1999). Consequently, religion often is at the core of individual and group identity.

Gurr (1993) defines religion as salient to ethnicity when it is a defining trait that sets a group apart in that group's own eyes and/or in the eyes of others. Because the importance of religion to ethnic identity is based on perceptions, this relevance of religion can vary over time. Horowitz (1985) makes a similar argument. Thus religion is an aspect of ethnicity with its importance varying over time and place. While it can be the single most important factor in some ethnic identities, it can have little relevance to others. The key factor which determines whether religion will be salient is the perception of the group itself and the efficiency of religion in providing the needs of the group (Fox, 1999).

Aside from the psychological impact, religion also offers a framework for legitimate opposition. Little (1991) argues that religion often plays an active and prominent part in defining group identity and in picking out and legitimating particular group objectives. This is because of the human need to elevate given political and economic arrangements in reference to sacred or cosmic standards (Fox 1999). This point has been addressed by several scholars who are studying religious fundamentalism. According to Marty and Appleby (1991) the current resurgence of religious fundamentalism is primarily due to a combination of factors. First, rapid modernization in 
formerly traditional societies has caused a considerable amount of social and personal dislocation. Second, the absence of mediating institutions capable of meeting the human needs caused by this dislocation has exacerbated the problem. Accordingly, religious fundamentalism is concerned with defining, restoring, and reinforcing the basis of personal and communal identity that is being shaken or destroyed by modern dislocations and crises. It provides a legitimate framework for opposition. For instance, different trends within the same spectrum of political and social ideologies in Algeria have drawn their strength from appeals to the values of Islam. These movements not only added a sense of dignity to the members of the movement but also provided a strong moral base for the opposition, which no other type of identity could offer (Spencer 1996).

\subsection{THE LITERATURE ON ISLAMISM: ORIENTALISTS vs. ANTI-}

\section{ORIENTALISTS}

\subsubsection{Orientalist Approach}

S. Sayyid (2003) divides the literature generated on Islamism into two currents: orientalists and anti-orientalists. In several respects, this parallels the debate on nationalism between Anthony Smith, with his emphasis on an enduring ethnic 'substratum' and Ernest Gellner, who stresses the ‘modernity’ of nationalism (Halliday 1995). The orientalist camp includes those who argue that the Islamic world is dominated by a set of relatively enduring and unchanging processes and meanings, to be understood through the texts of Islam itself and the language it generated.

Bernard Lewis is a leading scholar in the orientalist camp. He argues that in order to approach some understanding of the politics of Islam and Islamist movements, we must first try to understand the language of political discourse among Muslims, the way 
in which words are used and understood $(1988,5)$. To achieve such an understanding we have to look at the Qur'an and the traditions of the Prophet. According to this paradigm, Islam is comprised of a set of clearly defined and unchanging principles. This essentialist conception of Islam is combined with the belief that Islam is not simply a religion but a comprehensive way of life. This ahistorical and essentialist Islam is regarded as the independent variable determining the behaviors of the ruled and rulers and the social and political outcomes (Kazemzadeh 1998). Myron Weiner's understanding of Islam attributes Islam an ahistorical essence which will remain unchanged in the face of changing circumstances. According to him,

What is striking about the Islamic resurgence is its rejection of much of what is generally regarded as modern in the twentieth century: secularism, democracy, and even nationalism. In this respect Islam has come to play quite a different role from that of the religions of modernization- Christianity, Judaism, Confucianism, Shintoism, even Buddhism and Hinduism. Each of these religions, in its own way, has been interpreted or reinterpreted so as to induce people to behave in ways conducive to modernization, or to function alongside of, without impeding, modern behavior, yet to provide personal comfort, a sense of continuity with one's past, and a group identity $(1987,60)$.

Masoud Kazemzadeh (1998) further divides the scholars working within the orientalist camp into distinct subgroups: cultural relativists, and neo-Cold warriors. John Esposito (1991) is one of the representatives of the cultural relativists. Members of this subgroup do not use the term "fundamentalist" because they consider the current rise of Islamic movements as the latest resurgence of a cyclical phenomenon that has occurred 
throughout Islamic history. Instead, they use the term "Islamist". Scholars working within the framework of this subgroup tend to view Islam and Islamist movements in a positive light. They consider much of the antidemocratic policies of the Islamists as arising from either cultural differences or the temporary excesses of a few extremists (Kazemzadeh 1998, 52).

Despite the existence of scholars who analyze Islam in a positive light, most Western scholars who adapt the orientalist paradigm tend to have a very negative view of Islamic movements. This group of scholars constitutes the second group in Kazemzadeh's argument: neo-Cold warriors. They argue that the roots of dictatorship and repression of dissent in Islamic countries lie in Islamic faith and that Islamism is primarily a more assertive and political form of the Islamic faith. They consider Islamism as a major threat to Western interests in the post-Cold War period (Pipes 1995, 1996). Although there are sharp political differences that divide these subgroups, they all share an ahistorical and essentialized image of Islam. They treat Islam and Islamic faith as a whole of unchanging processes and meanings and make this conceptualization of Islam the independent variable of their analysis. Werner Schiffauer's study of the political culture of Sunni Muslims in Germany (1997) presents another line of thought within the Orientalist School. He examines the four Islamic groups in Augsburg, Germany and concludes that their degree of fundamentalism depends on their differential religious assumptions concerning the ideal relationship between individual and society and the ideal strategy for bringing about religious-political change. This line of thought shares the view of orientalism that in order to understand Muslim politics and its 
outcomes we have to look at Islam and the religious beliefs of those who take part in these outcomes instead of looking at outside factors.

\subsubsection{Anti-Orientalist Approach}

Against the orientalist approach, there emerged a substantial body of literature that denied any essence to Islam and instead looked at these Islamist movements as products of late twentieth century society. Edward Said is one of the most renowned critics of the orientalist school. Said (1981) criticizes the orientalists' treatment of Islam and Islamism as a monolithic entity and argues that Islam is an "unreliable index" of the phenomena that we are trying to understand (Said 1981, 61). He writes:

Thus far from being a coherent movement, the "return to Islam" embodies a number of political actualities. For the United States, it represents an image of disruption to be resisted at some times, encouraged at others. We speak of the anticommunist Saudi Muslims, of the valiant Muslim rebels of Afghanistan, of "reasonable" Muslims like Sadat, the Saudi royal family and Zia al-Haqq. Yet we also rail at Khomeini's Islamic militants and Qaddafi's Islamic "Third Way", and by our morbid fascination with "Islamic punishment" (as administered by Khalkali) we paradoxically strengthen its power as an authority-maintaining device. In Egypt the Muslim Brotherhood, in Saudi Arabia the Muslim militants who took the Medina mosque, in Syria the Islamic Brotherhoods and Vanguards who oppose the Baath regime, in Iran the Islamic Mujahideen, as well as the Fedayeen and the liberals: these make up a small part of what is an adversal current though we know very little about it. In addition, the various Muslim nationalities whose identities have been blocked in various post-colonial states 
clamour for their Islam. And beneath all this- in madrasas, mosques, clubs, brotherhoods, guilds, parties, universities, movements, villages and urban centres all through the Islamic world- surge still more varieties of Islam, many of them claiming to guide their members back to the "true" Islam (Said in S. Sayyid 2003, 36).

According to Said, the multiple meanings that Islam has demonstrate the inadequacy of the orientalist conceptualization of Islam. Said's critique has led a number of scholars to formulate an alternative approach: anti-orientalism. Anti-orientalists have produced a theorization of Islam in which they reject the essentialism of the orientalist camp. In anti-orientalists' theorization, Islam is not reducible to eternal fixed substantive properties (Sayyid 2003, 37). Anti-orientalist rhetoric finds its strongest voice in Hamid El-Zien's work (1977). He argues:

Neither Islam nor the notion of religion exist as a fixed and autonomous from referring to a positive content which can be reduced to universal and unchanging characteristics. Religion becomes an arbitrary category which as a unified and bounded form has no necessary existence. "Islam" as an analytical category dissolves as well (El-Zien in Sayyid 2003, 37).

Much of the anti-orientalist writing on Islamist movements have stressed not their invocation of 'tradition', or of a return to the past, but their contemporaneity and modernity: they were responses to problems experienced in these societies in the contemporary world- corrupt states, mass unemployment, chaotic urbanization, a sense of external domination. The programmes the Islamists offered and the ideas they propounded were similar to those of other Third World radical and populist movements, 
emphasizing such themes as oppression and liberation, corruption and authenticity, elite and mass. This approach argues that the rise of the Islamist movements is not just a return to some 'true' or 'authentic' tradition, but a response, at the level of peoples as much as intellectuals, to current problems.

According to Fouad Ajami (1981), the post-colonial elites aligned themselves with the West and blamed their own people for their society's backwardness, which led to the failure of nationalist secular elites. For Fischer (1982), this is the main reason for the rise of militant Islam. He argues that Islamism is a reaction to the failure of liberalism and Third World socialism. The rise of Islamism is presented as a reaction to the inability of the secular elites to meet the hopes and expectations of their people (Said 2003, 19).

Michael Gilsenan (1990) and Theda Skocpol (1982) are the two other proponents of the anti-orientalist approach. Michael Gilsenan argues that the authoritarian nature of post-colonial regimes led to the restriction of the legitimate public spaces. As a consequence the mosque emerged as the only arena of public discourse that the state did not have full control of (Said 2003, 19). Theda Skocpol makes a similar argument in her study of the Iranian Revolution. She focuses on the institutional networks of the Shia Ulema in overthrowing the Peacock Throne. The mosque emerged as the only viable public space, which led to the politicization of the religious vocabulary. The absence of democracy and the replacement of the desert and the mountains with the mosques as places of protests disrupt the previous balance between state and civil society, which forced elements to combine in their opposition to the state's expansion (Sayyid, 2003, 20). 
According to Nikki Keddie (1983), Islamism is the result of the crisis of the petty bourgeoisie. This crisis occurs because of the ambiguous consequences of the independence for the petty bourgeoisie. Although they dominated the post-colonial state through their recruitment into the ranks of an expanded administrative and coercive state apparatus, the petty bourgeoisie continued to lack access to power and wealth due to the continuing domination of the ruling elites, which resulted in the emergence of Islamism (Sayyid 2003, 20).

There is a common set of arguments that focuses on the relationship between economic processes and their political implications. Rapid economic growth leads to the destruction of traditional patterns of life. People respond to the uncertainty brought by this destruction by asserting and reasserting their traditional way of life. Islamism is a reaction to the consequences of rapid economic change (Sayyid 2003, 20).

In Fischer's account it is the internal migration and rapid urbanization that is responsible for the rise of Islamism (Fischer 1982, 102). Migration creates a large marginal population. The discontent is articulated by the rural migrants in the language that is most familiar to them: the language of Islamic ethics. The use of Islamic vocabulary in the articulation of grievances leads to the politicization of Islamic language, the result of which is Islamism (Sayyid 2003, 21).

Fred Halliday's Islam and the Myth of Confrontation (1996) is one of the leading works in the literature that advocates anti-orientalist approach. He rejects the argument of the orientalists that Islam can be taken as the explanation for social and political behavior. He argues that the rise of Islamist movements and the invocation of Islam as a justification for political action do not represent some general, transhistorical phenomena; 
they reflect particular forces within specific societies in the contemporary world. In other words, they are a response to current problems, often of a social and political nature. Where Islamist movements arise, they are responding not to a timeless influence as argued by the orientalists but to the issues their societies and communities face today. So if one tries to explain the rise of Islamist movements in Iran, Algeria, Afghanistan, Palestine and elsewhere, one can start by examining the problems facing the populations of these countries. If, in Western Europe, communities from Islamic countries increasingly define themselves in Islamic terms, this may not be so much a reassertion of some already existing Muslim identity. Instead it is a response to the problems of immigration and status, racist prejudice, employment discrimination and alienation that they face where they are now (Halliday 1996, 119).

Orientalists' understanding of Islamism establishes a direct relationship between Islam and Islamism. It assumes that there is an entity called Islam and considers Islamism to be simply a manifestation of Islam. Anti-orientalists, on the other hand, view the relationship between Islam and Islamism as an opportunistic relationship. They assume that the category of Islam is largely irrelevant for the understanding of Islamism. It is a label whose importance is due merely to its use as a source of symbolic authority and validation- its instrumentality (Sayyid 2003). They cannot answer the question why it is that Islam is being used rather than any other entity.

This study adapts the view of the anti-orientalist approach that the roots of the rise in Islamist movements do not lie in the essence of Islam but they should be looked for in the modern social and political context. However, it rejects the anti-orientalist conviction that Islam is just a label and therefore irrelevant for the understanding of Islamism. The 
relationship between Islam and Islamism is not direct as maintained by orientalists, nor is it merely opportunistic as argued by anti-orientalists. Rather, it is constitutive. Islam is not just the way in which structural interests are masked but it shapes and determines interests and identities. Both Islam and Islamism are transformed as Islamists try to articulate Islam to their project (Sayyid 2003, 46). In which discourse Islam becomes hegemonic is determined by the social, economic and political context within which Islamists operate. It can function as a cultural, social, political or religious signifier or it can be transformed into a master signifier within the Islamist discourse, the point to which all other discourses must refer. It can either offer an opposition strategy or a democratic participation strategy. In order to understand the place of Islam and the nature of its role in the Islamist discourse, Islam should not be taken as an independent variable, instead outside factors should be taken into consideration.

The variety of practices in the Muslim countries and within different Muslim groups indicates that Islam cannot explain how Muslims behave. Other factors outside Islam must be invoked. The resort to an all explanatory Islam is therefore circular. The study of Islamic communities cannot be based on a 'sociology of religion'; it must rather involve a sociology of how religion interacts with other ethnic, cultural and political forces (Halliday 1996, 124). Therefore, the study of Islamism should focus on external factors instead of treating Islam and the holy texts as independent variables. Islamism is not an irrational 'psycho-social regression' which has its roots in Islamic faith. It is a rational response given to social marginalization. However, the rational character of the movement does not deprive it off its emotive aspects. Islamism is a movement that draws its strength from its appeal both to the hearts and the minds of people. It offers an identity 
that "combines instrumental and affective ties" (Bell 1975). The Islamic movements seek to confront injustices in the state apparatus, social need, and economic exploitation. It offers an alternative to suffering. Islamism seeks to confirm Islamic identity through stressing the need for radical social change. Society is regarded as being characterized by social injustice, economic arbitrariness along with cultural and religious alienation. Using Islam as their chosen means, Muslim minorities in Western Europe are developing a region of consciousness and culture in which the social norms of the majority society do not count.

\subsection{THE CHANGING ROLE OF ISLAM WITHIN THE ISLAMIST DISCOURSE: AN}

\section{ALTERNATIVE PERSPECTIVE}

There is an underlying assumption within the literature on Islamism and

democratization that all the movements that subscribe to Islamism are hostile to democracy, that they advocate political violence and they have a totalitarian ideology (Cavatorta 2006). The labeling of all Islamist associations as being undemocratic because of a shared Islamic ethos does not reflect reality. This kind of understanding presupposes that Islam is incompatible with democracy a priori and assumes that all Islamist associations share the same outlook on organization of society. Islamist groups, however, vary both in ideology and methods from one another. They can become a counterhegemonic force by formulating an oppositional discourse towards the status quo and threaten the institutional structure. They can also be a potential force for democratization of the Islamic community by generating a political discourse that is couched in the language of democracy. The role Islamist associations play in society is determined by 
the role of Islam within the Islamist discourse which is shaped by the social, economic and political structure within which Islamists operate.

\subsubsection{Islamism as an Opposition Strategy}

The sociology of religion has focused on the positive role of religion in the maintenance of social order (Durkheim 1965; Parsons 1964; Wilson 1982). Studies by Pope (1942), Johnson (1961), Stark and Bainbridge (1985) and Troeltsch (1981) all stress the function of the church to integrate participants into the surrounding society. Yet, as pointed out by Solle (1984) and Billings (1990), religion must be understood in its double function: as legitimation of the status quo and as a means of protest on the other hand (Billings 1990, 2). Via the use of religiously charged language, social revolutionaries in Egypt, Algeria, Tunisia, Pakistan, and Turkey have used Islam to oppose the status quo. Islam has discovered a role as a frame of reference for socio-political groups in opposition: In Egypt there is the illegal Muslim Brotherhood, as well as mass Islamic organizations. In Algeria there is the Islamic Front. Tunisia, Pakistan and Turkey have their own equivalents (Wiktorowicz 2004).

Such resistance, however, is never automatic. According to Antonio Gramsci (1971), for religion to contribute to activism, it has to become a counter-hegemonic force. For a counter-hegemonic force to develop, the society needs a consciousness transformation which is a movement from common sense to critical understanding towards the system in which they operate (Billings 1990, 9). Capitalizing on socioeconomic injustices and the resulting alienation and marginalization, Islamist movements develop a counter-hegemonic discourse that aims to achieve a consciousness transformation. Only after this transformation can the movement become a counter- 
hegemonic force. Islamist movements take Islamic theology as their starting point in criticizing the existing system. They seek to confront injustices in the state apparatus, social need and economic exploitation. In their view Islam, as a model for society, offers an alternative to suffering. In the counter-hegemonic discourse, Islam is no longer one of many signifiers in the discursive universe but is a master signifier to which all other signifiers must refer.

\subsubsection{Islam as a Master Signifier}

Master signifier is a term borrowed from sign language and used by Jacques Lacan (1977) as a conceptual apparatus. Master signifiers are those signifiers that the subject most deeply identifies with and which have a key role in the way he/she gives meaning to the world. The master signifiers reorient the subject vis-à-vis all of the other signifiers which structure his/her sense of herself and the world (Lacan 1977). Slavoj Zizek used the term as a conceptual tool in the analysis of ideology. Zizek argues that ideologies work to identify individuals with important or rallying terms such as "God" in a theocracy, "the Party" under Stalinism, or "the People" in today's China. He calls these terms master signifiers, the most abstract principle by which any discursive space is totalized (Zizek 1989).

The master signifier gives meaning to other elements in the discourse. It functions "as the place of inscription for all other signifiers" (Sayyid 2003, 45). It unifies them and fixes their identity. It is the sole hegemon in the discursive universe and sustains the coherence of the whole ensemble. Islamism as an opposition strategy becomes a counterhegemonic discourse and ultimately a counter-hegemonic force by transforming Islam from one of many signifiers in the life of a Muslim community to a master signifier. It 
places Islam at the centre of its discourse and above all other discourses. Islam becomes a discursive object that has monopoly over all other discursive formations. It regulates all aspects of life as the sole authority.

Islamists make Islam the master signifier by unifying the ways Islam operates in different discursive configurations. They define Islam as din (faith), as dunya (worldly life and concerns), and as dawla (a political order). The Islamist project traces the existence of Islam in different discourses and unifies them in a counter-hegemonic discourse to which all other discourses must refer. Thus, Islamist discourse in which Islam is the master signifier becomes an alternative to every aspect of the dominant society: its economy, its social relations and institutions. Islamism confirms Islamic identity through stressing the need for radical social change. Society is regarded as being characterized by social injustice, economic arbitrariness and political irresponsibility along with cultural and religious alienation. So Islam offers a third way. It offers a model for future society. Islamism stresses the socio-political dimension in a religious context (Pedersen 1999, Gerholm and Lithman 1988).

A brief look at political argumentation in the Middle East and North Africa reveals the innumerable examples of this kind of Islamism. The Islamic Salvation Front of Algeria, for example, galvanized the opposition of the young and unemployed to the existing single party government and legislature by making references to the opposition of Prophet Muhammed to the Meccans (Spencer 1996). Muslim Brotherhood in Egypt, al-Nahda in Tunisia, Jamaat-i-Islami in Pakistan are other examples of Islamism as an opposition strategy in which Islam is the master signifier. 
Using Islam as their chosen means, Muslim minorities in Western Europe are developing a region of consciousness and culture in which the norms of the majority society do not count. The development which this expresses exists not only at an individual level, but also at a collective one. The new organizations that are being established within the framework of these movements not only break with established political unions among ethnic minorities, but also with forms of religious-political expression such as are represented by national cultural associations which often refer back to official religiosity and politics of their country of origin (Pedersen 1991)

All these Islamist movements mark the emergence of a counter-hegemonic force in the face of political, social and economic challenges. In the form it takes in Germany, Islamism becomes a resistance to marginalization. It is the response of the Turkish immigrant community to the economic, political and social marginalization which is perceived as a threat to their existence as individuals and as a community. They choose Islamism as their means of resisting this marginalization because Islamism is offered as a discursive element of rupture, a structural antithesis to Western thought which is believed to be responsible for the disadvantaged position of the Muslim immigrant community in Germany.

\subsubsection{Islamism as a Democratic Participation Strategy}

While Islamism might be offered as an opposition strategy in the face of exclusion and marginalization, it can become a democratic participation strategy in an inclusionary democratic system. Such a system can produce an Islamism that is not in conflict with the democratic order in two ways. First, the perceived lack of socioeconomic injustice legitimizes the democratic system and results in the conviction that 
democracy is capable of delivering justice and equality. Second, by providing Islamists legitimate means of participating in society, it creates an environment where they can learn and internalize democratic processes. As a result, democratic participation is considered as a legitimate and effective way of claims-making.

In a society which is believed to value ethnic, religious, cultural and political pluralism, Islamism offers itself as a legitimate way of participating in the public space. By stressing the Islamic identity, Islamism provides its followers the opportunity to exist as Muslims in the public space. In the Dutch context, Islamic identity, the contours of which are drawn by the Islamist discourse, allows the Muslim immigrant community to exist in Dutch public space. It is through the Islamic identity that the Muslim immigrant community finds a channel of contact and communication with the Dutch authorities. Organizing under the Islamic identity provides Islamism the legitimacy it needs both in the eyes of Dutch authorities and the Muslim immigrant community. Islamists exist in Dutch public space not despite their Islamic identity but because of it. The Islamism that is formulated in an inclusionary democratic system reflects the learning process that takes place within the Islamist movement as a result of its experience with the Dutch society, in which democratic principles were internalized. Within such an Islamist discourse, Islam is transformed into a religio-cultural signifier.

\subsubsection{Islam as a Religio-cultural Signifier}

Contrary to Islam's role as a master signifier in oppositional Islamism, Islam is one of many signifiers within the discourse of Islamism that is offered as a democratic participation strategy. Islam is not the hegemonic discourse in every aspect anymore; rather it serves as a religious and cultural signifier. It gives meaning to elements in the 
religious and cultural sphere. While Islam as a master signifier is defined as din (faith), as dunya (worldly life and concerns), and as dawla (a political order), Islam as a religiocultural signifier is defined as din (faith), and as dunya (worldly life and concerns). Such Islamism transforms the existence of Islam in the political sphere from being the form of the political order to being the moral authority over that political order. Within Islamist discourse that operates in a democratic system that is considered legitimate, there are two systems of meaning: one provided by Islam as a religio-cultural signifier, the other provided by democracy as a political signifier. While the Islamic ethos governs the religio-cultural life, the democratic ethos governs the political sphere. Within the framework of this discourse where Islam constitutes the religio-cultural signifier and democracy constitutes the political signifier, Islamism provides the means for participation in the democratic process.

In the Dutch context, the Islamism that is formulated by IGMG is the outcome of a learning process that took place within IGMG as a result of its experience with the Dutch society. The perception that Dutch society is tolerant and just has resulted in conceptualizing democracy as a legitimate system of government within IGMG. Therefore, both democracy and democratic processes were internalized and became part of the Islamist discourse as a political signifier while Islam was kept as a religio-cultural signifier. Having developed under the conditions of peaceful coexistence, Islamism has become a strategy of democratic participation. It has provided its followers the opportunity to exist as Muslims in a Western context and become actors who participate in the making of society. 


\subsection{CONCLUSION}

The alternative perspective that is offered in this study rejects the essentialism of the orientalist approach and structuralism of the anti-orientalist approach and urges us to look at the dialectical relationship between the forces that push immigrant communities outside the system or integrate them into the structure and Islamist discourse in order to understand Islamism. Orientalism imposes a historical essence to Islam. Anti-orientalism, on the other hand, rejects the existence of such an essence and treats Islam as superstructural, a form of false consciousness and thus minimizes its significance. Theorizing the relationship between Islam and Islamism as a dynamic and dialectical relationship, this study takes a position in between these two approaches. It argues that contrary to what anti-orientalists argue, Islam matters, but not because of the reasons orientalists provide (Sayyid 2003). It matters because the elements in its essence, the notion of Islam as din (faith), as dunya (worldly life and concerns) and as dawla (a political order) for example, make it possible for Islam to be the hegemonic discourse in different discursive configurations. In which discursive configurations it will assume the hegemonic role is determined by the structure in which Islamists operate.

An exclusionary democratic structure that pushes the Islamic community outside the system lacks legitimacy in the eyes of the Muslim community. Such a system is susceptible for a counter-hegemonic discourse in which Islam is a master signifier to emerge. The counter-hegemonic discourse carries out the consciousness transformation that is necessary for a counter-hegemonic force to occur. Through this consciousness transformation, the "common sense" that West and its products such as democracy and secularism are morally superior is transformed into a critical understanding of Western 
society in which Western norms and values are portrayed as inferior and replaced by Islamic ones. The result is the emergence of a counter-hegemonic force which offers itself as an alternative to norms and institutions of the host society.

An inclusive democratic structure that is believed to provide equal rights and opportunities to its members, on the other hand, is capable of producing an Islamist movement that embraces democracy as a legitimate system of government. The Islamist discourse that is developed in such a structure defines Islam as a religio-cultural signifier and democracy as a political signifier. Islamism becomes a force for democratization of the Islamic community.

Contrary to the general assumption that Islamist movements are hostile to Western notions of democracy, secularism and rule of law because of a shared Islamic ethos, this study suggests that Islamist movements vary in their ideology, discourse and methods. In order to understand the relationship between the Islamist movement and Western institutions, it is essential to understand the place of Islam within the Islamist discourse, which is shaped by the structure in which Islamists operate. The forces of the structure might push Muslims outside the system paving the way for an oppositional Islamism or they might integrate them into the structure and create an Islamism which embraces democratic norms. By focusing on the immigration and citizenship laws of Germany and the Netherlands, next chapter will analyze these forces and the processes of marginalization and integration. 


\section{CHAPTER 3}

\section{SYSTEMIC PROPERTIES OF GERMANY AND THE NETHERLANDS: LAWS,}

RULES AND REGULATIONS THAT AFFECT THE IMMIGRATION EXPERIENCE

A significant outcome of the post World War II labor migration was Europe's rediscovery of Islam. From the perspective of the European societies, accepting Muslim immigrants posed a challenge: perceiving them as permanent settlers and integrating them into their economic, social and political systems. From the perspective of the migrants, the challenge was how to achieve social justice, fair and equal treatment for themselves and their families without having to compromise their identities and cultural heritage (Layton-Henry 1990). Although it can be argued that integration is a two-way street, the European countries ultimately have the decisive hand in the management of Islam. Their laws, rules and regulations in regards to immigration and immigrants shape the immigration experience at two levels: the individual level and the organizational level.

The citizenship laws and recognition of Islam as an official religion are the two most important systemic factors that determine the place of Islam and Muslims within the European public and social space. Citizenship is a question of inclusion in or exclusion from a political community (Habermas 1994). Marshall divides citizenship rights into three major categories: civil, political and social (Marshall 1963). By civil rights he refers to the rights that are necessary for individual freedom: liberty of the person, freedom of speech, thought and faith, the right to own property and the right to justice. The most important aspect of political rights is the right to participate in the exercise of political power and decision-making process. The means to exercise this right is by voting in local 
and national elections. Social rights include the right to a minimum and humane standard of living and to a share in economic welfare and social security benefits as well as educational and health benefits (Layton-Henry 1990). By defining the boundaries of national belonging, regulating the level of political, social and economic participation for immigrants, citizenship laws determine the actors of the public sphere and the nature of the interaction between members and non-members. In this respect, citizenship laws shape the immigration experience at the individual level.

At the organizational level, the legal status of Islam plays an important role. The legal status of Islam is shaped by the relationship between the state and the religious institutions in the host country. In Germany, the state is regarded not as being laicist in the French or Dutch form; rather it is religionsneutral, meaning that it does not take a position on religious affairs. The distinction is important because in Germany the state and religious institutions are not rigidly separated. The Jewish community, the Catholic and Protestant churches all have the status of a recognized religious community which provides them with rights and privileges in important sectors of society such as education. Being recognized religious communities, they have access to public schools, hospitals and other welfare institutions. Islam, lacking this kind of status, is confined to its own borders outside the institutional structure of the host society. The institutional exclusion has two important consequences. First, it creates a sense of discrimination and thus alienation leading to social and institutional arrangements that close the Muslim immigrant community to outside intervention. Second, it leads to the intervention of the Turkish state in the religious life of the immigrant community. Excluded from participation in the democratic structure of German society, Islamic organizations' 
institutionalization is unregulated. Concerned about this lack of control in the institutionalization of Islam in Germany, Turkey plays an active role in the religious organizational life of Turkish immigrants. Turkey's presence leads to reactions from more conservative segments of the immigrant community resulting in their joining to movements that are not in line with Turkish Islam.

The Netherlands, on the other hand, adopted the principle of strict separation between church and the state. The Dutch state is considered to have equal distance to all religions including Islam, which satisfies the sense of justice and equality on the part of the Muslim organizations. The traditional Dutch "pillarization system" grants all religions the right to establish their own institutions including schools, creating a social space for Islam to institutionalize under democratic norms. The Dutch government's active involvement in the institutionalization process of Islam and the existence of formal and informal channels of communication between the government and the Islamic organizations abolish Turkish state's incentives for intervening in the religious life of immigrants. This creates more locally oriented Islamic organizations that function as a bridge between the immigrant and the host society.

Laws, rules and regulations of host countries do more than just organize the public life of immigrants. By defining members and non-members of the political community and the nature of the relationship between them, they not only determine who gets what but also who is what. They shape perceptions and identities and thus the destinies of generations of immigrants and their own communities. 


\subsection{FROM MIGRANT LABOR TO ETHNIC MINORITY: THE TURKS IN WESTERN EUROPE}

The presence of Islam in Western Europe is essentially a consequence of labor migration which started in the 1960s (Pedersen 1999: 23). The indigenous labor force was not adequate to meet the needs of the expanding Western European economies after World War II. These countries needed workers to replace soldiers and civilians killed in the war. Gaps were partially filled by migrants from rural areas but more workers were needed (Moch 2003: 176).

Due to this increasing demand for a work force that could satisfy the needs of the growing European industries, the Western European countries signed bilateral agreements with Southern European countries and Muslim or Arab countries including Pakistan, Algeria, and Turkey. The first phase of postwar migration mostly from the Muslim countries marked the start of a new phase in European migration history, which introduced a new debate on the definition of national identity in Europe (Pedersen 1999: 23).

\subsubsection{Germany}

West Germany was the last nation to recruit foreign workers. The recruitment process was organized by the Federal Labor Office (Bundesanstalt) and West Germany became the country with the highest foreign worker population in Western Europe (Moch 2003: 180). Germany made a bilateral recruiting agreement with Italy in 1955 and with Greece in 1960. When the construction of the Berlin Wall stopped the flow of East Germans into the West in 1961, Germany signed a recruiting agreement with Turkey, Morocco, Portugal, Tunisia and Yugoslavia. By the end of the sixties almost 3 million 
foreigners lived in West Germany, mostly from Italy, Yugoslavia and Turkey (Moch 2003: 184).

Turkish migration to Europe was first and foremost migration to West Germany. Germany and Turkey had friendly relations. Turkey was a strategic ally and the workforce of Turkey was underemployed. In 1961, Germany signed a bilateral recruiting agreement with Turkey, which resulted in the entry of over 8,700 Turks into West Germany by the end of 1961 . The number grew to 72,476 in 1965 . By 1974, over a million Turks resided in West Germany, constituting a quarter of the foreign population (Moch 2003: 187).

In the late 1960s, due to the increasing demand for Turkish women workers by German employers, Germany recruited low-paid female workers for electronics, textiles, and garment work. Turkish women entered the German labor force, manufacturing car parts, assembling clothes and packing candies. Their husbands and fathers encouraged them to take up industrial work abroad so that they could secure positions for their male relatives at a time when jobs for men were in decline (Moch 2003: 187). As a result of the increase of the number of women in the German labor force and family reunification, a third of Turkish entrants were women by 1967.

The oil crisis and recession that began in 1973, the immigrants' visibility in local markets and cities due to their ethnic and racial distinctiveness and their growing numbers fueled anti-foreign incidents in Germany which once enthusiastically greeted the foreign workers that were desperately needed for the economy. The immigrant families become more visible than single male workers who were housed by their employers in the dormitories (Heime) close to the factories and kept apart from society. Migrant 
children entering the public school system, children's allowances, and housing programs all added to the societal stress regarding the immigrants leading to efforts to stop immigration altogether. In 1973, West Germany cut off immigration by banning the entry of workers from non-EEC countries (Moch 2003: 189).

Attempts to cut off immigration had adverse effects. Since the male workers could not risk a visit home, their families joined them in Europe, increasing the absolute number of foreigners in Germany by 13 percent between 1974 and 1982. Despite ethnic prejudice, hostility from the host society, poor housing and social problems, in 1980s it became evident that Turks, the guest workers of the 1960s, were becoming resident minorities. Today 2.4 million Turks live in Germany, 1.88 million of which have Turkish citizenship. They present the largest foreign population in Germany (Sen 2004).

\subsubsection{The Netherlands}

After World War II, war-torn Dutch economy which lost a significant amount of its labor force needed to rebuild itself. Since the Dutch nationals moved into the service sector after the rapid economic growth, foreign laborers were required to fill the low and unskilled sectors of the economy. The Dutch government signed recruitment agreements in mid-1960s mainly with Turkey and Morocco but former Dutch colonies also supplied labor force to the country. However, it was only Turkey and Morocco that was included in the "guest worker" program. With the "guest worker program" which was widely employed by European nations after World War II, the Dutch economy satisfied the growing need of its economy for foreign labor. The term "guest worker" was used because the assumption was that the workers would rebuild the host country and return to their homelands after a short period of time. 
Active labor recruiting slowed down with the oil crisis of 1973 but a steady migration stream remained due to family reunification. Thus instead of returning to their home countries, many of the guest workers stayed in the Netherlands and reunited with their family members on Dutch soil (Hines 2004: 154). In 1981, 148,000 Turks lived in the Netherlands, constituting almost 50 percent of the foreign population (Moch 2003: 181). Today Turkish minority in the Netherlands is one of many minority populations in the country. The Antillean and Surinamese migrants are postcolonial nationals whereas Turkish and Moroccan migrants are former guest worker recruits. According to the Dutch Central Bureau of Statistics nearly 325 thousand Turks live in the country today (CBS 2007 report).

\subsection{LEGAL, ECONOMIC AND SOCIAL STATUS OF TURKS IN GERMANY AND THE NETHERLANDS}

Immigration raises important questions not only regarding access to territory but also immigrants' integration into the political, social and economic structure of the host country. The immigration process determines the nature of the inter-societal relations by providing answers to questions of rights, duties and identity: who has the right of entry; what kinds of political rights do the immigrants have; what options do they have in the labor market; what level of social integration does the host country expect from the immigrant. The answers to these questions refer three core elements underpinning the nation state: the sovereign control over external borders, the regulation of political rights and a nation's cultural self-understanding. These are questions of "inclusion within, or exclusion from, the national political community" (Takle 2007: 3). 
Citizenship is considered a question of inclusion in or exclusion from a political community in the academic literature (Takle 2007, Habermas 1994). By defining certain groups (in Germany these are asylum-seekers, guest workers, Aussiedler) and determining to which group each immigrant belongs, the host society justifies its methods of controlling the flow of migration (Takle 2007: 3). The categories do not simply reflect the existence of different types of migration but also the perceptions about national political community and self-understanding of the host country.

Citizenship also means membership in a community; it is not just a physical belonging but a political one. The right to citizenship implies the right to vote and thus participation in a political community. Citizenship is an exclusive status, which draws a boundary between ins and outs (Takle 2007: 3). By defining the boundaries of national belonging, regulating the level of political, social and economic participation for immigrants, citizenship laws determine the actors of the public sphere, letting some actors in, leaving some out. In this respect, the immigration process and citizenship laws are important in understanding the inter-society dynamics of a given country.

\subsubsection{Germany}

Unlike other comparable nation-states which have based their citizenship laws on a mixture of jus sanguinis (citizenship based on descent) and jus soli (citizenship derived from place of birth), Germany has always refused to adopt the latter basing its citizenship law on common descent only (Marshall 2000: 139). Ethno-national German citizenship law and the official treatment of "foreigners" have been a source of uneasiness for the Western observers. A French journalist asked in 1991: "How can a country that is so proud of its modernity continue to live with this relic called the blood law? With a law 
that privileges the descendants of Swabian peasants who emigrated two hundred years ago to the steppes of central Russia, and rejects the children of Turkish immigrants in Kreuzberg, who know no horizon other than the Kottbusser Tor or the Kurfurstendamm?” (Hoffmann 1999: 357).

After the brutal arson attacks on Turkish homes in Western German cities of Molln in 1992 in which three Turkish girls died and Solingen in 1993, in which five women and girls of Turkish descent lost their lives (Kinzer 1993), criticisms have been raised against the ethno-national character of German citizenship by foreign commentators (Hoffmann 1999: 357). Although reform of citizenship law has been promised by the government for years, as of yet very few changes have been implemented. Article 116 of the Basic Law still defines a German as a member of a “community of descent” (Abstammungsgemeinschaft) (Hoffmann 1999). The definition of Germanness in terms of common descent (jus sanguinis) rather than in terms of territorial inhabitance (jus soli) is seen as the main obstacle in front of a peaceful coexistence of German citizens and non-German immigrants. How can the historical continuity of jus sanguinis be explained? In order to answer this question, it is necessary to look at German national self-understanding in a historical context.

\subsubsection{The Continuity of Jus Sanguinis: Understanding It within the Historical Context}

The present German regulations regarding immigrants and naturalization are based on the Reichs und Staatsangehorigkeitsgesetz (RStG) of 22 July 1913 with its ethnic definition of citizenship. The 1913 Basic Law went back to the Prussian legislation which reflected Prussia's concern with its Eastern European and Polish immigrants who were considered as "undesired elements" (Marshall 2000: 139). 
The shortage of manpower in the German agrarian and industrial sectors in 1890 led to the importation of foreign labor, which resulted in an increase in the foreign population (mostly Eastern European Jewish businessmen and Polish foreign workers) from 270,000 in 1871 to more than 1.2 million by 1910 . However, the Jewish businessmen or the Polish foreign workers in the German Kaiserreich were never perceived as immigrants or potential Germans. Rather, they were treated as foreign laborers whose presence was acceptable only if it served the interests of the state and economy. German states took official measures to accept foreign workers into the German lands but at the same time denying them any political rights. This administrative practice was made into law with the Reichs- und Staatsangehorigkeitsgesetz of 1913. It denied the legal right to naturalization to the foreigners and their children who lived in the German Keiserreich, "while making it possible for the Germans who settled outside the Reich maintain their citizenship for an unlimited period of time" (Hoffmann 1999: 359). Although in theory, foreigners could apply to be citizens if they had legal capacity, clean police record, proof of income and domicile, in practice the immigration authorities of the Kaiserreich systematically discriminated against certain groups such as Eastern European Jews and Poles (Hoffman 1999: 359).

One of the distinguishing features of German citizenship was its pre-national character. The citizenship was granted by the individual states before the existence of a nation-state. German nationality was defined as belonging to a German Kulturnation, which refers to membership of those who shared German "culture" and values. This approach was maintained after the foundation of the German Reich in 1871. The 1913 Act was based on Prussian legislation. It was both inclusive and exclusive (Marshall 
2000: 139). It included in the German nation those who have German background but lived outside the country. In the Weimar Republic this provision provided citizenship to those Germans who found themselves outside Germany as a result of the defeat in the First World War. After the Second World War, it allowed ethnic Germans to return to the Federal Republic after generations of life in the east. On the other hand, it excluded foreigners such as Poles in the $19^{\text {th }}$ century and even the third generation foreigners such as Turks in the $21^{\text {st }}$ century (Marshall 2000: 139).

There is continuity in Germany's approach to citizenship. The definition of citizenship in terms of ethnic descent served as a special tie for "a nation in search of a state" (Brubaker 1992: 5). After 1945 the ethnically based citizenship served to keep the nation together by granting citizenship to the inhabitants of the formerly German territories in the east and to those of GDR (Marshall 2000: 139). After the national unification was achieved in 1990, the old justification for maintaining the ethnicallybased citizenship law disappeared but Germany continued its century old tradition.

Some countries like France also started with jus sanguinis as the legal basis for nationality but added jus soli for foreign children born in France as early as during French Revolution. Germany, however, refused to adopt jus soli. All attempts by the Social Democrats to introduce a citizenship policy based on jus soli have been rejected (Marshall 2000: 140).

\subsubsection{Legal Definition of Immigrant}

Maintaining an ethnic definition of citizenship through the Basic Law had important consequences on the politics of immigration in Germany. Although it is the responsibility of the federation to formulate and implement policies regarding 
immigration according to the Basic Law, there has not been a comprehensive immigration law so far. Germany has not adopted an immigration policy because of two reasons. The first one is reflected in the term kein Einwanderungsland. The policy that Germany is not an immigration country was officially adopted in 1977, a time when there were already 4 million immigrants in Germany (Geddes 2003: 80). The second reason is the lack of a distinct legal category for immigrant. The Federal Republic classifies those entering into Germany into several different legal categories that "cannot be subsumed under one general concept of immigrant" (Hoffmann 1999: 361). There are three groups. The first one is Statusdeutsche which includes those who come from GDR, the former German eastern provinces or Eastern European countries. Since they have the automatic right to German citizenship, their entry into Germany is not considered to be immigration but rather return. The second group is the asylum seekers who enter Germany under Article 16 of the Basic Law, which guarantees asylum to the politically persecuted (Hoffmann 1999: 361). In the third category are the foreign workers from non-European Union countries and their families who entered Germany as a result of the bilateral agreements with the countries of origin between 1955 and 1973 (Hoffmann 1999: 361).

The German terminology used to categorize foreign workers summarizes the nature of the relationship between Germans and non-Germans in the country. While most countries use the integrative term immigrant, denoting a person who comes into the country and settles there, Germany uses an excluding term Auslander (foreigner) to define its guestworker population, underlining their temporary existence in the country. By contrast, foreigners in Germany have spent much of their lives in Germany. According to the Federal Statistics Office of Germany (Statistisches Bundesamt, 1998), 
29 percent of them in 1996 had spent twenty years or more in Germany or more, 11 percent of them spent fifteen to twenty years, 8 percent between ten and fifteen years and 14 percent between six and ten years.

The legal definition of immigrant and this system of categorization reflects the self-understanding of Germans while it affects both the self-understanding of "foreigners" and their living conditions. Christhard Hoffmann (1999) gives an example of a hypothetical situation in which three young Poles from the same village would each be conferred a wholly distinct legal status in order to illustrate the effect of the legal categorization on their living conditions. According to the hypothetical situation of Hoffmann, the first might be recognized as a German citizen upon entry because his German grandmother had married a Pole after the war. He would immediately be granted all the rights of citizenship and also accesses to an extensive network of social services, including unemployment and welfare benefits, as well as to special programs that would help him get situated in his new country. The second might have come as an asylum seeker. He would be barred from employment and be placed in a residence for asylumseekers till his case is finalized. Supposing his petition was denied, he might have been granted permission to stay in Germany as a refugee for a limited time. During this time he would only be allowed to accept a job if there were no German citizens to fill it. The third might have worked in Germany during the summer time and returned to Poland after three months in order to do the same next year (Hoffmann 1999: 362).

This hypothetical case illustrates the reasons for the continuity of jus sanguinis in a century when there is increasing global immigration and Germany's counter-factual premise that it was not a country of immigration. The legal categorization of immigrants 
into "Germans" and "foreigners" is a reflection of this understanding and shapes the selfunderstanding of immigrants by limiting their options in the labor market, their channels for political representation and forcing them to create their own social spaces where their values are shared by the majority and they can hold a positive identity.

\subsubsection{Citizenship Law of Germany}

Up to 1990, naturalization was governed by Section 8 of Reichs- und Staatsangehorigkeitsgesetz of 1913. Except during the Third Reich, the 1913 Basic Law governed the western part of Germany until it was replaced in 2000 (Takle 2007: 5). This

law which was based solely on the principle of jus sanguinis, allowed citizenship if certain requirements such as fixed place of residence, the means of supporting themselves and their dependants and the leading of "an irreproachable life" are fulfilled (Marshall 2000: 141). Even if these conditions were met by the applicants, the final decision was left to the discretion of the German officials whose decisions neither needed to be justified nor could be legally challenged (Takle 2007: 5).

According to the Naturalisation Guidelines of 1977 (Einburgerungsrichtlinien) applicants had to prove their loyalty and commitment to Germany by a good command of written and spoken German (paragraph 3.1.1.), knowledge of the Federal Republic political system, loyalty to its democratic order and at least ten years' residence in the country (paragraph 3.2.1). The Naturalisation Guidelines outlined the open impediments to naturalization such as activities in political emigrant circles which was seen as a lack of commitment to Germany. In particular, the Guidelines refer to the undesirability of dual nationality. Naturalisation applicants, except for the nationals of formerly German territories in Eastern Europe and the former Soviet Union, had to give up their prior 
nationality. The nationals of formerly German territories in Eastern Europe, however, had a legal right to German nationality under Article 116 of the Basic Law without having to give up their own (Marshall 2000: 141).

The combination of the 1913 Citizenship Law and the naturalisation guidelines of 1977 meant that naturalisation was considered an exception, not the normal practice (Takle 2007: 5). It was granted only if served public interest (Marshall 2000: 141). Paragraph 2.3 of the guidelines made the official position of Germany regarding immigration clear by stating that "the Federal Republic is not a country of immigration; it does not seek deliberately to increase the number of German citizens through naturalization" (Naturalisation Guidelines 1977, parag. 2.3).

Two changes to the naturalization process were introduced with the Foreigner Law of 1990: temporary easier naturalization for foreigners who had lived in Germany for more than fifteen years (Section 86) and for foreigners between the ages of sixteen and twenty-five if they had been resident in Germany for at least eight years, had been educated there for six years and had no criminal record (Marshall 2000: 142). In these cases the discretion of the German officials to deny naturalization was limited. Dual nationality was tolerated under exceptional circumstances (Marshall 2000: 142).

Another important change came with the new Citizenship Law of 2000, which granted access to citizenship to second and third generation immigrants. With the introduction of this law, the principle of ethnic descent (jus sanguinis) was combined with the territorial principle (jus soli) so that children born in Germany could become German citizens (Takle 2007: 6). One condition was that they had to choose between 
German nationality and their first nationality between the ages of eighteen and twentythree since the state would not accept dual citizenship for adults.

Naturalisation, however, has remained a laborious process, which is reflected in the low naturalization figures. According to the figures of Statistisches Bundesamt total naturalization in 2006, excluding the ethnic Germans from Eastern Europe, was 124,566, which is almost 1 percent of the foreign population. Despite the fact that over 40 percent of foreigners in Germany fulfilled the fifteen years residential precondition, the naturalization figures of Germany is the lowest in Western Europe. One of the reasons for the low figure is the lengthy, complicated procedure that takes on average twelve months (Marshall 2000: 142). But the most important reason is the exclusion of dual nationality in all but exceptional cases. The majority of the respondents that were interviewed for this study mentioned that they did not want to apply for German citizenship because they did not want to give up their Turkish nationality since it would mean giving up their inheritance rights and right to buy property in Turkey. Adherence to their Turkish nationality is a practical and psychological necessity (Marshall 2000: 143).

\subsubsection{Political Rights of Foreigners}

The most important component of political rights is the right to participate in the exercise of political power and the decision-making process. The most obvious means of political participation is by voting in local and national elections. (Layton-Henry 1990: 11). Since majority of Germany's Turkish immigrant population do not have citizenship, they lack basic political rights and social equality that is associated with the status of citizenship (Marshall 2000: 140). Despite their lack of citizenship, they could have still had voting rights at the local level as is the case in some Western European countries but 
in West Germany, non-national immigrants have no voting rights. By denying its long term foreign residents who have been contributing to German economy since 1960s the right to participate in the local and European elections, Germany has been acting against one of the most important democratic principles (no taxation without representation) (Marshall 2000: 140).

There is a disagreement among politicians and legal experts as to whether the federal constitution prohibits the political participation of non-national immigrants. According to Article 20, Paragraph 2, "All state authority emanates from the people" but there is confusion over who "the people" are. A minority argue that they are all inhabitants of West Germany and whatever their citizenship, all foreign residents should be allowed to take part in all elections while others argue that "the people" means German citizens only (Rath 1990: 127).

Whatever legal experts have to say on the issue, the enfranchisement of foreigners is ultimately a political, not a juridical decision. The enfranchisement of immigrants at the federal or state level requires a constitutional amendment but the necessary two-thirds majority in both the Bundestag and in the Bundesrat cannot be secured, leaving almost 10 percent of the population outside the political decision-making process (Statistisches Bundesamt 2005).

\subsubsection{Economic Status of Turkish Immigrants: From Guest Workers to Ethnoclass}

Economic opportunity is another aspect of the environmental structure of the larger society that plays an important role in the integration process of an ethnic group. Economic success and its accompanying upward mobility can provide incentives for integration (Fellow, 1972; Befu, 1965), but restricted economic opportunity may induce 
ethnic groups to use economic adaptive strategies, such as the formation of ethnic niches, which may deter integration (Barth, 1969). If there is limited access to economic opportunity, ethnic group members may resort to the formation of closed ethnic associations and neighborhoods for protection and thus isolate themselves even more from the larger society (Wong, 1974). Finally ethnic groups may use their ethnicity as a resource for socioeconomic activities and thus perpetuate the ethnic boundary (Wong, 1978).

Since the end of the 1970s, when the return migration of recruited laborers declined, the unemployment rate of Turks in Germany has been continuously above the rate of the total labour force. It is striking that the unemployment rate of Turks has also been above the level of all foreigners in the country. Since the beginning of the 1990s, Turks' unemployment increased markedly. While in 1990 the rate was at 10\%, in 1997 it reached $24 \%$. The rate decreased slightly to $22.7 \%$ in 2002 . Although citizens of other recruitment countries have also experienced high unemployment rates, Turks' rate of unemployment is higher (Ozcan, 2004:5).

Unemployment could have several causes. In the case of Turkish immigrants, their disproportionably high share in manufacturing industries, where job opportunities have been declining since the 1980 s as well as their comparatively poor educational structure have been the key. According to the study of Ozcan (2004), Turks clearly have a worse educational structure than Germans. In 2002, 26\% had left school without diploma whereas the share among Germans was much lower at 2\% (Ozcan 2004:5).

Though school certificates are an important indicator of a group's educational structure, more crucial for the position on the labour market are vocational qualifications. 
It is striking that Turks commonly remain without formal vocational training. This is a trend which holds true for the second generation as well. The vocational qualification structure of Turks and Germans has only changed little between 1997 and 2002. In 2002 $71 \%$ of Turkish migrants had no vocational qualification, while $25 \%$ had completed formal vocational training. In 2002, $42 \%$ of second generation Turks had completed formal vocational training. However, still every second (54\%) among them was without a vocational certificate (Ozcan 2004:6).

In $199782 \%$ of total Turkish labour force was employed as blue-collar workers whose main activities are often characterized by hard physical work, mental strains because of shift work and corresponding effects on health. Until 2002 this share declined by $10 \%$. In $200262 \%$ of second generation employed Turks worked in blue-collar jobs, the share in the comparable German group was much lower at 28\% (Ozcan 2004:8). As a result of the increasing unemployment rate and discrimination, the share of the selfemployed among the second generation increased from 2\% in 1997 to 5\% in 2002. Turkish immigrants established ethnic businesses in Berlin. The initial market for immigrant entrepreneurs arose within the ethnic community itself. The geographical concentration of the ethnic group made it profitable for the entrepreneurs to establish businesses within the ethnic community. Moreover, due to the geographical concentration of the Turkish immigrants, social ties among the members of the ethnic group are very strong. These strong social ties are particularly important for Turkish immigrant entrepreneurs to mobilize financial and human capital. Surveys conducted in Berlin show that most Turkish businesses have been established thanks to the financial and human support of the co-ethnics. Altogether, the firms surveyed employ 412 persons, of whom 
23 percent are family members and 65 percent are of Turkish origin. Ethnic businesses developed first in areas such as groceries, butcher shops, pubs, restaurants, bookstores and video stores, among others. Survey results show that Turkish firms were set up to satisfy specific demands from the Turkish community that lives in ethnic neighborhoods. About 76 percent of the enterprises set up by Turkish immigrants in Berlin are in retail trade and catering, while 45 percent of Turkish firms have mainly Turkish customers (Bayar 1996).

Bocker's analysis of the report for the Sussmuth-Commission reveals that the public sector in Germany is not accessible for immigrants. According to the report "They (the immigrants) are heavily under-represented in the civil service. Civil servants in Germany are categorized into career civil servants and employees. Most career civil servant positions are only accessible to Germans. However, immigrants are underrepresented among employees as well. Seifert produced the following data for NorthRhine Westphalia in 1999. Foreigners from former recruitment countries made up $7.8 \%$ of the North-Rhine Westphalian labour force. In the public sector, however, this share was only $2 \% \ldots$ In the sector of public administration, the proportion was $1.4 \%$, in the social insurance sector $1.5 \%$. In the educational sector, it varied from 2.3 to $3.7 \%$ ...”(Bocker 2004:24).

Upward social mobility is one of the most important manifestations of immigrant economic integration. Germany's score on providing equal opportunities and equal outcomes for Germans and non-Germans is not promising either. According to a timeseries study conducted by Seifert (1994), while Germans experienced upward mobility from semi-skilled and skilled manual positions to white-collar jobs, foreign workers 
experienced downward mobility. 65 percent of the foreigners who occupied skilled manual workers' posts in 1984 still occupied such posts in 1989 but 27 percent had dropped into un- or semi-skilled jobs and only 5 percent had moved to white-collar jobs. The figures for the second generation are similar (Bohning \&Beijl 1995: 9).

High unemployment, low income levels, poor educational structure and vocational qualifications, lack of upward mobility leaves Turkish immigrants in Germany at the bottom of the social pyramid, creating an ethnoclass which is inherited by generations.

\subsubsection{The Netherlands}

Contrary to Germany where the institutional structure and the attitudes prevailing in the country with respect to the immigrants can be characterized as assimilationist, the Netherlands is known for its multi-culturalism. The prevalence of the institutional arrangement of verzuiling (literally "pillarization"), relatively easy naturalization process, voting rights in local elections, and right to dual citizenship have provided the immigrants in the Netherlands an environment where they can be integrated into the host society yet preserve their ethnic/religious identity. The identity-affirming multicultural policies are channeled through Dutch "pillarisation" and minority policies.

\subsubsection{Dutch "Pillarization" (Verzuiling)}

Pillarization is "the institutional arrangement which enables mutually interdependent social and political groups to maintain their autonomy to a perceived optimum, without a distinct geographical basis and within the frame of national sovereignty, ensuring the integration of these groups to a minimal degree while 
preventing the national identity or the social order from being jeopardized" (Sturm, Groenendijk, Kruithof, Rens 1998: 283).

Since the late $19^{\text {th }}$ century each religious and ideological community in the Netherlands formed its own institutional structure (e.g. schools, hospitals, housing corporations, trade unions, newspapers), which enabled the members of these communities live their lives in line with their values (Entzinger 2003: 64). The pillarization was first introduced as a result of the organized opposition against educational innovation from 1870 s onwards from different denominational streams. These pressure groups of the school law opposition continued to exist as powerful pressure groups. They were transformed into political parties, the most important of which were the neo-Calvinist and Roman Catholic parties. These parties were the “crystallization" of different ideologies which would later be called zuilen (pillars) of Dutch society (Sturm 1998: 288).

Starting from the second half of the $19^{\text {th }}$ century the Netherlands developed into a multicultural society, which was divided along ideological lines and yet "living apart together" harmoniously (Sturm 1998: 288). This multicultural system which was divided into different subcultures, isolated from each other but working together at the national level has been called "consociational democracy" by A. Lijphart $(1968,1985)$. The state has encouraged the existence of different ideological networks by incorporating them into the public order. By allocating state subsidies through the pillars according to the proportionality principle, distributing public money for educational, social and cultural purposes, the Dutch state has made these ideologically based organizations a salient feature of the welfare state in the $20^{\text {th }}$ century. A pluralistic organization of society in 
which functional differentiation was superimposed by world view differences has become the hallmark of the Dutch society with pillarization (Sturm 1998: 288). Despite the arguments that the Netherlands has moved away from the traditional notion of pillarization in the 1970s (Entzinger 2003), Dutch society still remains a multiculturalist society which is built on the notion of pillarization. This notion is further institutionalized by the Dutch ethnic minorities' policy.

\subsubsection{Dutch Ethnic Minorities' Policy}

Contrary to Germany where immigrants are referred to as Auslander (foreigners), the Netherlands perceive migrants in terms of their group membership calling them ethnic minorities. Ethnic minorities' policy took shape in the early 1980s. In 1979 the Scientific Council for Government Policy (WRR) published a report called Ethnic Minorities which stated that most migrants were going to stay in the Netherlands for good and a policy effort was needed to promote their incorporation. In 1980, the government approved the Council's views, which marked the beginning of Dutch ethnic minorities' policy (Entzinger 2003: 62).

Ethnic minorities' policy was laid down in the Minderhedennota, which was approved by Parliament in 1983. Ministry of the Interior was given the task of coordination of minorities' policy, the rationale being the implementation of minorities' policy at the local level (Entzinger 2003: 63). The underlying assumption of the minorities' policy was that the Netherlands had become a multi-ethnic society as a result of immigration and the minority groups living in the country should live in harmony, mutual understanding and respect for each other. It was the main responsibility of the public authorities to create the necessary conditions for the peaceful coexistence of these 
groups by providing equality of opportunity for everyone (Entzinger 2003: 63). The Minderhedennota outlines the main objective of the ethnic minorities' policy which became known as "integration with retention of identity" as "Achieving a society in which all members of minority groups in the Netherlands, individually and also as groups, are in a situation of equality and have full opportunities for their development" (Minderhedennota 1983:10).

Han Entzinger (2003) summarizes the basic objectives of Dutch ethnic minorities' policy under three headings: 1) emancipation in a multicultural society 2) equality before law 3) promoting equal opportunity.

1) Emancipation in a multicultural society

The notion of emancipation in a multicultural society is the continuation of institutionalized pluralism which is known as pillarization in the Netherlands. It reflects the traditional Dutch understanding that minorities should be given the opportunity to emancipate by preserving their identities and developing their own institutions. Generous public funding has been provided to immigrant social and cultural life, such as subsidies for ethnic organizations, newspapers etc. Mother tongue teaching was expanded to five hours in primary education and the establishment of Muslim and Hindu schools was initiated. Although Dutch law does not allow for financial support to mosques or churches, certain social and cultural activities organized by the Muslim communities have been subsidized by the Dutch government (Entzinger 2003: 65), which all aimed to contribute to the notion of emancipation in a multicultural society. 
2) Equality before the law

The second objective of the ethnic minorities' policy is to provide equality before the law. The policy stated that ethnic minorities should not be forced to take up Dutch citizenship and should not be disadvantaged because of their foreign citizenship. The government took some measures in order to eliminate the differential treatment such as lifting the ban for foreign residents on entering the public service with only few exceptions such as the armed forces and the police. Long term foreign residents were granted the right to access to social security system and other social policy instruments in exactly the same way as the Dutch citizens (Entzinger 2003: 65).

Another measurement taken by the government to ensure the equal treatment is granting voting rights to foreign citizens at the local level in 1985. Since then, foreign citizens with a residence record of at least five years have been able to vote and be elected in local elections. Since immigrants have had the right to vote, Turkish turnout at the local elections has always been high (Entzinger 2003: 66), indicating the positive effects of the policy initiative on the political integration of the Turkish immigrants.

\section{3) Promoting equal opportunity}

The third element of Dutch minorities' policy is promotion of equal opportunity which is articulated in the assumption that minorities should participate in Dutch institutions such as housing, healthcare, education and employment in proportion to their size and this should be achieved by making these institutions accessible to these groups. Measures were taken to ameliorate the housing conditions of the ethnic minorities which has been quite successful. Housing conditions of ethnic minorities have become similar to those of the Dutch of comparable socio-economic status (Entzinger 2003: 68). 
By introducing certain forms of preferential treatment, the government aimed to overcome selective treatment in the labor market. A special law was introduced in 1993 which obliges employers to report on the ethnic minority share in their staff on an annual basis (Entzinger 2003: 69). Although there are problems in enforcing the law, it has a great symbolic value since it reflects the multiculturalist attitude at the state level.

\subsubsection{Dutch Citizenship Law}

Until 1984, the Dutch citizenship laws were based on the Dutch Nationality Act of 1892 (Wet op het Nedelanderschap en het ingezetenschap), which was based on the principle of jus sanguinis (acquisition of Dutch nationality by descent). In 1953 the automatic attribution of Dutch nationality from the time of birth was extended to all children of the third generation the result of which was an increase in dual or multiple nationality by birth (Groenendijk \& Heijs 2001: 145). The 1953 amendment to the 1892 law introduced jus soli to the jus sanguinis character of the 1892 law. In 1976, the 1892 Nationality Act was amended for the last time in order to simplify the naturalization procedure.

The Nationality Act of 1984 replaced the 1892 law. According to the 1984 legislation, there are three possibilities for non-Dutch immigrants and their descendants to acquire Dutch nationality. Third generation immigrants who are "children born to a father or mother residing in the Netherlands at the time of the child's birth and who himor herself was born of a mother residing in the Netherlands" automatically acquire Dutch nationality at birth (Groenendijk \& Heijs 2001: 147).

Second generation immigrants (individuals aged 18 to 25 who were born in the Netherlands and have resided there since their birth) can acquire Dutch nationality by 
making a unilateral declaration. According to the law there are no further requirements and the persons concerned are not required to renounce their foreign nationality (Groenendijk \& Heijs 2001: 146).

Both the earlier amendments made to the 1892 law and the introduction of the second generation's right to make a declaration and the retention of the provision for the third generation are reflections of the Dutch minorities' policy, one of the aims of which was to strengthen the legal status of non-Dutch minorities (Groenendijk \& Heijs 2001: 146). With the amendments most children of immigrants acquired Dutch nationality through the naturalization of their parents.

First generation immigrants can only acquire Dutch nationality through naturalization. Applicants have to meet the following conditions:

- "be at least eighteen years of age;

- have been granted unlimited residence in the Netherlands by the immigration authorities;

- have resided in the Netherlands for at least five consecutive years prior to the application;

- have reasonable knowledge of the Dutch language and be reasonably integrated into Dutch society;

- do not constitute a danger to public order, public morals, public health or the security of the kingdom;

- have made an effort to renounce his or her foreign nationality, unless renunciation cannot reasonably be expected" (Groenendijk \& Heijs 2001: 147). 
In 1991 the Dutch government coalition of Christian Democrats (CDA) and Social Democrats (PvdA) abolished the renunciation requirement for naturalization. Starting on $1^{\text {st }}$ January 1992, immigrants who wanted to acquire Dutch nationality did not have to renounce their original citizenship (Hart 2007: 77). The abolishment of the renunciation requirement resulted in a considerable increase in the naturalization rates while 80 per cent of the naturalized immigrants retained their first citizenship. 86 per cent of the Milli Gorus members that were interviewed for this study had both Turkish and Dutch citizenship. Although in 1997 the requirement for applicants to renounce their foreign nationality was reintroduced, the effect of the new legislation is limited since dispensation has been granted to 13 categories of applicants. These categories include:

- "nationals of states that do not allow their nationals to renounce their nationality;

- nationals of states that are party to the Second Protocol of the 1963 Strasbourg Convention; persons born in the Netherlands;

- $\quad$ persons married to a Dutch national;

- recognized refugees;

- persons who would suffer substantial financial damage as a result of renouncing their nationality;

- persons who can only renounce their nationality after engaging in military service or buying their way out of military service;

- $\quad$ persons who can prove that they have special and valid reasons for not renouncing their foreign nationality" (Groenendijk \& Heijs 2001: 148). In practice the overwhelming majority of applicants are in one of these categories. According to Kees Groenendijk and Eric Heijs (2001), the main changes in nationality 
law had a clear effect on the number of naturalizations. They observed a clear increase in the number of foreigners acquiring Dutch nationality in the years immediately after the 1976 and 1985 legislative changes and after the changes in the rules on dual nationality in 1992. The majority of the Milli Gorus members interviewed in the Netherlands stated that the introduction of the dual nationality right played a very important role in their decision to acquire Dutch nationality.

Despite the changes introduced in the new Citizenship Law 2000 which made access to naturalization more difficult and the reinstatement of the renunciation requirement in 1997, the institutional arrangements in respect to immigrants in the Netherlands still reflect the underlying spirit of institutionalized pluralism in the Netherlands which aims for a multicultural society where different ideologies can retain their distinctiveness while coexisting peacefully. Contrary to the assimilationist German structure, the multiculturalist Dutch public institutions have provided its immigrants the opportunities to be integrated into the social, economic and political structure of the host society.

\subsubsection{Economic Status of Turks in the Netherlands}

Similar to the Turkish community in Germany, the Turks in the Netherlands are unfavored in the labor market. According to the statistics conducted by EUROSTAT for France, Germany and the Netherlands, migrants of both first and second generation persistently score worse than nationals in Germany and the Netherlands in terms of average unemployment rates (Bohning \& Beijl 1995). The contributing factors to the relative labor market disadvantage of Turks compared to indigenous workers are their over-representation in the more vulnerable unskilled occupations especially in 
manufacturing and the host society's knowing or unknowing discrimination against nonnationals.

Despite the similarities in the disadvantaged position of Turks in terms of unemployment, the Netherlands scores better than Germany in terms of upward socioeconomic mobility which is one of the most important manifestations of socio-economic integration. The details of the occupational status of the Milli Gorus members will be provided in the next chapter but it is important to look at the number of Turks employed as blue-collar and white-collar workers. While in Germany 4 per cent of the interviewed Milli Gorus members held blue-collar jobs, in the Netherlands this number goes up to 11 per cent. Since in Germany majority of the Turkish immigrant community are not German citizens, they are not qualified for civil servant positions. In the Netherlands, on the other hand, 2 per cent of the Milli Gorus community works as a civil servant as a result of the Dutch anti-discrimination law and the high rate of naturalization among Turks.

The existing literature on the labor market position of immigrants suggests that there are two groups of factors that explain the differences in the labor market position of Turks in Germany and the Netherlands: individual factors such as differences in education level, gender, age, generation, migration motives, regional origin of Turks in Germany and the Netherlands (urban versus rural areas) and contextual factors such as discrimination, training system, policy factors such as immigration, integration and citizenship policies (Dagevos, Euwals, Gijsberts \& Roodenburg 2007).

The study of the Milli Gorus community reveals that the individual factors such as migration motives, regional origin of Turks in both countries are quite similar in 
Germany and the Netherlands. The difference in the upward socio-economic mobility can be explained by the difference in the contextual factors such as the immigration, integration and citizenship policies and the training systems in these countries.

The Netherlands has taken various labor market measures to fight the disadvantaged labor market position of the immigrants. Among them is the Jeugdwerkgarantiewet (JWG) which offers training and vocational practice to unemployed youngsters. Another measure taken by the Dutch government to alleviate unemployment among immigrants is Bijdrageregeling Vakopleiding Leerlingwezen (BVL) which runs subsidized vocational training and apprenticeship schemes in favour of unemployed youngsters. The public subsidies increase if ethnic minority members enter the schemes (Bohning 1995). Similar incentive schemes have been used in different contexts in the Netherlands. For example:

if an employer hires a long-term unemployed person for a regular job he is exempt for up to four years from the obligation to pay social security contributions...Long-term unemployment within the scope of this programme means at least two years of unemployment. For ethnic minorities unemployment of one year is considered to be equivalent (Bohning 1995: 17).

While the Netherlands adopted several labour market insertion measures, Germany did not elaborate such measures that foreigners can benefit from. In addition to these measures, the Dutch vocational education has also contributed to the integration of Turks into the Dutch labour market. The vocational education is offered at the secondary education level but the students can continue their vocational training at a higher level through vocational colleges. Vocational education is preferred mostly by the immigrant 
families to improve the labour market opportunities of their children. The institutional arrangements such as the similarities of the curriculums used by general and vocational education institutions make it easy for the students of vocational education switch to general or higher education, which is crucial for the attainment of upward socioeconomic mobility. Contrary to the German system which has separate vocational tracks with their own institutions, there exists genuine opportunities to switch between general and vocational education at each level in the Netherlands (Dronkers 1993).By contrast, in Germany vocational education does not allow such a switch, locking Turkish immigrant children into the ethno-class to which their parents have belonged for decades.

Despite the similarities in the disadvantaged position of Turks in terms of unemployment, the Turks living in the Netherlands have better chances of upward mobility than Turks residing in Germany. The contextual factors such as immigration, integration and citizenship policies and education system are the factors that explain the differential rate of economic integration in these two countries.

\subsection{INSTITUTIONALIZATION OF ISLAM IN GERMANY AND THE}

\section{NETHERLANDS}

Although Islam's history in Germany and the Netherlands stretches back over 250 years, it enters a new era with the immigration of the 1960s and 1970s. The arrival of the immigrants from the Middle East and other Muslim countries in the 1960s resulted in the establishment of Islamic institutions however it was not until the 1980s that these institutions really began to emerge. Up until the 1970s, the immigrants were primarily men. They came to Germany and the Netherlands as guest workers who were going to return home once they had the financial means to establish a new life for themselves and 
their families in Turkey. However, things did not turn out the way they expected and families reunited in Europe in the 1970s. With the family reunification the social profile of the immigrant community which formerly consisted of men dramatically changed. The arrival of women and children and the accompanying family life changed the needs. New questions were raised concerning family life, ethics and morality, questions that are concerned with religious matters. As it became clear that their existence in Europe was not temporary, ritualizing of the most important events such as weddings, funerals, childbirth, the circumcision of male children and observation of religious celebrations required organization (Pedersen 1999: 24).

The mosque associations that are established today among Turkish immigrants in Western Europe were created by the immigrants themselves as a response to this growing demand as a result of changing societal needs. The institutionalization pattern of these mosques and other Islamic organizations took different forms in Germany and the Netherlands. While these Islamic institutions took a path away from the German public sphere, creating parallel societies that function outside the host society, they have become part of the Dutch institutional structure operating along with Dutch authorities in the Netherlands. This difference in the institutionalization pattern of Islamic organizations is explained by the difference in Islam's legal status in each country. By not formally recognizing it as a religious community, Germany pushes Islam outside the public sphere forcing it to institutionalize as an alternative to the German welfare state. By providing social and economic services and a positive identity, Islamic organizations gain the allegiance of its followers. By contrast, the Netherlands integrate Islam into its legal structure. Through public funding for Islamic organizations and Islamic schools, the 
Dutch government creates a legal and social space for these organizations where they can operate within the Dutch system yet retaining their identities.

\subsubsection{Institutionalization of Islam in Germany}

According to the German Constitution, called the Basic Law, the state is regarded not as being laicist in the French or Dutch form but it is regarded as religionsneutral. While in the French or Dutch form of laicism the state and religious institutions are rigidly separated, in Germany the state does not take a position on religious affairs. The Jewish community, the Catholic and the Protestant churches all have the status of a publicly recognized corporation (Korperschaft offentlichen Rechts). The state collects a church tax from the members of the churches and distributes the tax to the churches after deducting an administration charge. The regional states and the churches work closely in areas of common concern such as education. 80 percent of the publicly funded nursery schools, a number of hospitals and other welfare institutions are run by the churches (Nielsen 2004: 28).

The religious communities that have not been granted such recognition operate under the law of association. Since Islam has not been recognized as a religious community by the German government, Muslim organizations operate under the category

of registered association (eingetragener Verein or e.V.). In order to be recognized as a registered association, the association must have a democratic structure with a membership list. The structure of an association is controlled by a group of trustees who check the administration and responsibility of properties regularly (Nielsen 2004: 28).

While the officially recognized religious communities of Jews, Catholics and Protestants cooperate very closely with the state authorities in areas of education, welfare 
and health, the Muslim associations have been excluded from the policy-making process. This exclusion resulted in Turkey's active involvement in the religious life of the Turkish immigrant community by establishing DITIB (Diyanet Isleri Turk Islam Birligi), the Religious Authority's Turkish Islamic Associations in 1984. Turkey's role as the administrator of Islam in Germany alienated the more conservative segment of the immigrant community leading to their break away from the DITIB and joining more radical movements such as Milli Gorus.

Islam's legal status as a non-recognized entity has further effects in the institutionalization of Islam in Germany. According to the German Constitution, religious instruction can only be carried out under the aegis of a religious community. Since Islamic organizations in Germany have not been granted the status of a religious community, they cannot gain access to the public schools, which leaves the Islamic education to the hands of the various Islamic movements. Parents who want their children to get Islamic education have no choice other than sending them to mosques that are owned by different Islamic movements. Ayse is a 32 year-old woman who came to Germany 10 years ago with family reunification. She has two sons, one 11, the other 9 . Her statement summarizes the implications of German policy of not granting legal status to Islam.

We often come to the Suleymanci movement's mosque in Cologne. I had no idea about them before I came to this country. My husband used to go to the DITIB's mosque but now he goes to the Suleymanci's mosque. He says they give better Islamic education to children and have nothing to do with the Turkish state (Interview with Ayse, 2 June, 2005). 
Some might argue that the management of Islam lies in the hands of the Muslim state apparatus or the Muslim immigrants themselves but looking at the development of the Islamic scene in Europe it is ultimately the European countries which have the decisive hand in administrating Islam.

\subsubsection{Non-Governmental Islamic Organizations in Germany}

Starting from the late 1960s, the Turkish immigrants established their own mosques in rooms, garages and outhouses. Occasionally, when they found the resources, they bought warehouses and small deserted factories and turned them into mosques (Interview with Metin Turkoz, June 12, 2007). By 2000, there were over sixty mosques and 2,000 other spaces for worship (Nielsen 2004: 28).

Until the late 1970s, the most active Turkish Muslim groups were those that were banned or disapproved by the Turkish state. One of the major, if not the major, religious movements was the Avrupa Milli Gorus Teskilati (AMGT) which claimed to have the support of half of the Muslim population of Berlin in the early 1980s (Nielsen 2004: 29). It was founded in Germany in 1971 as Turkische Union Deutschland (Turkish Union Germany). It was renamed Milli Gorus (National Vision) in 1976 and eventually became Islamische Gemeinschaft Milli Gorus in 1994. It was known for its militant attitude to German society and Turkish politics. The movement's ideological roots go back to the ideas and concepts developed by Turkish politician Necmettin Erbakan and his National Salvation Party (MSP) and its successors which were banned in Turkey for violating Turkey's laic legislation. The Milli Gorus movement has an estimated 26,500 members in Germany and owns around 2,200 facilities such as mosque communities, women's youth and sports clubs (Milli Gorus website). It is identified as a terrorist group by the German 
Federal Ministry of the Interior (Annual Report 2005 on the Protection of the Constitution).

Another Islamist movement that was banned by the Turkish state in the 1970s is the Avrupa Islam Kultur Merkezleri Birligi, the association of Islamic Cultural Centres in Europe, known in German as Verband Islamischer Kulturzentren e.V. This group represented the European branch of the Suleymanci movement, an Islamic brotherhood, or tariqa, organized along centralist principles (Pedersen 1999). The movement is named after its founder, Suleyman Hilmi Tunahan and aims to introduce shari'a in Turkey through alliances with mainstream political parties. It controls almost 200 mosque associations and "fraternal groupings" in Germany, which are constituted with e.V. status. The movement organizes activities in opposition to official Islam in Turkey, stressing openly its Sufi character and therefore it has been under surveillance by the German government (Nielsen 2004: 29).

The Nurcu movement (The Fellowship of Light) has extended its influence among the young generation of Turkish immigrants in the last ten years. Although early supporters of the movement settled in Germany long before the Turkish immigration started, it was not until the 1970s did the Nurcu movement took an organized form. It supports the introduction of Shari'a in Turkey but prefers to work strategically forming secret alliances. The rationale behind the secret alliances is the idea of gaining slow, gradual control of state administration (Pedersen 1999: 31). While they have kept a low profile politically and not been engaged in the turmoil of the Turkish political conflicts of the late 1970s, they have been active in educating Muslim youth along the lines of their religious doctrine. 
Another religious community that keeps a low profile in the organized Muslim life of Germany is the Alawi-Muslims, a Shi'a Muslim sect. The community's organization rests on family and clan structures. Women are allowed more freedom of movement. Modern Alawi theology is influenced by humanism and universalism. Today, many young Alawis conceive Alawism in non-religious terms. They consider it as an ethnic or cultural identity. The Alawi religious tradition hardly requires mosques. Alawi worship takes place in assembly houses (cemevi). Therefore, the Alawi community is not visible in the organized religious life of Germany (Nielsen 2004: 31).

According to Mehmet Ocal, who is a former Milli Gorus member in Germany and currently a professor of International Relations at Erciyes University in Turkey, Turkey could not meet the demands raised by the Turkish immigrant community in the 1970s in Germany. The result was the institutionalization of Islamist movements such as Milli Gorus, Suleymanci movement, and Nurcu movement among the Turkish immigrant community. These movements, the majority of which were banned by Turkey for opposing the laicist legislation, spread their ideas through TV and cassette tapes. In the 1980s Turkey realized that it was in their best interest to administer Islam among the Turkish immigrant community in Germany by organizing and financing the imams. As a result of Turkey's concerns regarding the spread of Islamist movements among the Turkish immigrant community in Germany, Diyanet, the central arm of Turkish religious policy, established a German branch in 1984, headquartered in Cologne.

\subsubsection{Turkey as Administrator of Islam in Germany}

Although Turkey has been sending imams to Europe since 1975, it was not until the establishment of the DITIB (Diyanet Isleri Turk Islam Birligi), the Religious 
Authority's Turkish Islamic Associations, in 1984 that systematic efforts to organize the religious life of the migrant Turks started to take effect (Pedersen 1999: 26). Although DITIB officially defines itself as an independent umbrella organization and stresses the point that it has no "organic links to official or private organizations" in effect it is the Turkish state's body for religious affairs abroad. The Turkish Diyanet Isleri Baskanligi, or Directorate for Religious Affairs, is part of the prime minister's office and responsible for the delegation of state imams and employees of DITIB (DITIB's official website). These imams have the status of civil servants of the Turkish Government. They work in Germany on a temporary basis and are replaced every four years.

DITIB comprises a number of registered cultural unions that are called 'eingetragene Vereine' (e.V.). Both the DITIB and the organizations under it align themselves with the official Turkish line on Islam. The association's articles state that the objective of the union is to safeguard the interests of the Islamic religion in cooperation with the Republic of Turkey by producing and conducting programs for Islamic religious teaching, providing organizational and financial support in making the hajj pilgrimage and dispensing educational and doctorate bursaries to those who are in need of financial support (DITIB's official website).

Today DITIB has 870 cultural unions. If not officially, in effect DITIB is the Turkish state's body for religious affairs abroad. Turkey's role as administrator of Islam in Germany is due to Islam's lack of recognition as a religious community by the German government. The statement of one of the theologians who came to Germany 20 years ago and has been working in the DITIB in Cologne since then illustrates the official approach of the Turkish state towards its role in Germany. 
In the 1980s when we were sent to Germany, we were told that Germany was like a jungle where different religious communities were trying to get a piece from the pie. They were all fighting for the same thing: winning the hearts and minds of the confused immigrant community. The competition was harsh and needed to be regulated. If Germany was not willing to do it, Turkey would. We simply could not afford to lose the community to radical Islamists (Interview with Mustafa, May 22, 2005).

By not granting recognition to the Islamic organizations, Germany showed its unwillingness to "regulate the competition" between different Islamic organizations, which resulted in Turkey's involvement. The role of Turkey in the religious organizational life of Turkish immigrants as the administrator of Islam alienated an important segment of the Turkish immigrant community. Hasan, like many others who expressed similar views, states that he broke away from the DITIB and joined the Milli Gorus movement because of the close ties between the DITIB and the Turkish state.

DITIB is the continuation of the mentality that diminishes the role that Islam plays in the public life and reduces it to an individual matter. Despite their denials, DITIB is in the service of the Turkish state and I do not like that (Interview with Hasan, 27 May, 2006).

\subsubsection{Islamic Education in Germany}

The governance of public schools, and thus the issue of Islamic education, is under the jurisdiction of the individual states in Germany. The federal states differ in their approach toward Islamic education. Since the 1980s, the states that have a large population of migrant children have offered native-language education. These 
supplemental programs offer Islamkunde, instruction in Islamic culture from a nonconfessional perspective (Mohr 2002). The issue is further complicated by the fact that German constitution grants the right to provide religious instruction in public schools to religious communities. Since Islam has not been granted the status of a religious community, Islamic organizations do not have access to public schools (Mohr 2002).

The number of Muslim children, especially Turkish children, attending the nursery schools in all the major cities of Germany is increasing day by day. Eighty per cent of nursery schools are run by the Protestant and Catholic churches and funded by the state authorities (Nielsen 2004: 35). The parents of Turkish children attending these schools have placed demands on the staff and the system. However, the main problem is that while these schools are funded by the state, the staff are recruited and employed by the responsible church agency (Nielsen 2004: 35).

The main aim of these agencies is to provide a Christian upbringing for the children who attend these schools. Since a change in the curriculum or the staff composition would contradict with the main purpose of these schools, the school authorities have been rejecting the appointment of Turkish nursery teachers. A few Muslim nurseries have been established but as part of a Muslim association. Being a private initiative, they are excluded from public funding.

All the states provide complementary mother-tongue teaching which is provided by Turkish teachers. Islamic religious education has been part of this complementary teaching. In the early 1980s, only in Bavaria was there a regular period of two hours devoted to Islamic religious instruction. This was taught by Turkish teachers according to the syllabus designed for Turkish schools. However, the educational standard of the 
teachers and the content of the syllabus have to be approved by recognized church authority (Nielsen 2004: 36).

The question of introducing Islamic religious instruction as a separate subject for Muslim children has been one of the most debated topics in Germany since mid-1970s. The education authorities have been resisting Muslim demands for facilities similar to those of the churches on the grounds that Islam does not have the status of a religious community. The result of exclusion of Islamic instruction from the public schools is increasing monopoly of different Islamist movements on Islamic teaching. The Turkish parents who are not satisfied with the Islamic education as part of the complementary teaching in public schools send their children to mosques or Qur'an schools that are owned by Milli Gorus or Suleymanci Movement. When asked why she chose to attend the Milli Gorus mosque, Yildiz, a mother of 4, stated that it was the only place that her children could get proper Islamic religious education (Interview with Yildiz, June 7, 2007).

In 1980, in a report on the policy of the state towards foreigners, the government of North-Rhine-Westphalia, the state with the largest Muslim population in the Federal Republic, decided to counter the monopoly of the Qur'an schools. This was to be achieved by making stronger reference to the cultural and religious characteristics of the Muslim community and introducing suitable Islamic religious instruction. This would bring Qur'an instruction into the schools, ending the monopoly of the various Islamist movements on Islamic education.

This, however, was not a simple task. The law of the state required that religious instruction be implemented in cooperation with the recognized religious community. 
Once again the legal status of Islam became the main hurdle to a positive and constructive initiative which, if implemented, could have ended the monopoly of Milli Gorus or Suleymanci movement on Islamic education that not only isolates the Turkish immigrant community from the host society but also creates a social space where an orthodox version of Islam is praised.

\subsubsection{Institutionalisation of Islam in the Netherlands}

In the Netherlands, there are about 950,000 Muslims $(5.8 \%$ of the whole population) in the Netherlands at present (Central Bureau of Statistics-Central Bereau voor de Statistiek- 2004). While the earliest Muslim population in the Netherlands originates from the former Dutch colonies, the large influx of Muslim immigrants in the 1960s and 70s came from Turkey and Morocco. The formation of Muslim organizations started in the 1970s.

The Dutch "pillarization system" gives religious groups the right to establish their own infrastructure on the basis of their ideologies and also to be subsidized by the government. The Dutch constitution guarantees freedom of religion and education as well as the subsidizing of private schools founded on religious bases (Shadid 1991).

In its Note of Minorities of 1983 the Dutch Government devotes serious effort to create a society in which the members of the minority groups living in Holland will have equal opportunities and full chances of developing. Its policies aim to create the conditions required for emancipation and participation in society and prevent the discrimination of minority groups. The Government acknowledges that it is important to take into consideration the cultural, including the religious, background of minority groups in order to construct a "multicultural society". Its policy implies an equal respect 
for the religious beliefs of various groups, including the Muslims. The Dutch Government stresses that "Religion fulfills a function in developing and enforcing the self-respect and hence the emancipation of many members of ethnic groups" (Shadid \& Koningsveld 1991: 90).

The subsidizing of mosques by the national Government was brought to an end in 1984 on the grounds that it was against the laic nature of the state. However, many local authorities have been helpful in establishing places of worship. In 1983 the Waardenburg Committee advised that the local administrations should place some of the premises owned by them at the disposal of Muslim organizations and enable them to establish a place of worship there. The interests of the Muslim communities wanting to establish mosques have been protected by the constitutional principle of religious freedom and the Bill of Public Manifestations issued in 1988 which acknowledges the right to publicly perform the Muslim call for prayer (Shadid \& Koningsveld 1991: 90).

The Supreme Court of the Netherlands issues a decree in 30 May 1986 giving the imams exactly the same legal position the law had given ministers, priests and rabbis. They are all considered as "persons with clerical offices." This decree is important in the sense that it offers equal opportunities to imams in all branches of Dutch society. Imams, just like clerics, can be employed outside their traditional positions within local religious communities such as in the army, in hospitals, prisons, etcetera (Shadid 1991).

Despite the recent weakening of the pillarization system, it still exists in the most important sectors of society such as education, hospitals, trade unions and broadcasting stations. Unlike in Germany where recognized religious communities are privileged before the law, the Netherlands adopts the policy of equal treatment of all religious 
groups acknowledging religion's role in developing and enforcing the self-respect and hence the emancipation of ethnic groups. It is this pluralistic approach embedded in the pillarization system that explains why the Dutch juridical system is more flexible to Muslims and other religious minorities than that of other European countries (Shadid 1991).

\subsubsection{Non-Governmental Islamic Organizations in the Netherlands}

The Turkish Islamic Cultural Federation (TICF) which was founded in 1979 in Rotterdam is the largest Turkish umbrella organization in the Netherlands. It had seventyeight member associations by the early 1980 s and reached 140 by the end of the 1990 s. The official objectives of the organization are to serve the interests and to promote the emancipation of the Turkish Muslim community and stimulate the integration and participation of this community within the Dutch community. It played a major role in the formation of the state-financed Islamitische Omroep Stichting (Islamic Broadcasting Foundation) (Shadid 1991). TICF works closely together with the Islamitische Stichting Nederland (Netherlands Islamic Foundation), an organization founded in 1982 and directly linked to the Turkish Directorate of Religious Affairs (Diyanet) in Ankara which provides the TICF with the imams it employs in its member mosques (Nielsen 2004: 65).

The Islamic Center in the Netherlands owns about twenty mosques, with its main office in Utrecht. This is the Dutch branch of the Suleymanci movement, whose European headquarters is in Cologne, Germany. The movement has been represented in Holland since 1972, which makes it the oldest Islamic movement in Holland. It refuses to cooperate with the official Turkish line of Islam. Today they have around 30 mosques in Holland concentrating mainly on Qur'an education. They also teach classical Arabic. 
This educational centre was established by Suleyman Hilmi Tunahan who taught religious law, dogmas and the stages of the inner path which became the spiritual guide for the Naqshibandi order, a mystical movement within Sunni Islam (Shadid 1992).

The mosque associations of Milli Gorus, which is an offshoot of the Turkish oppositional Milli Gorus movement centered around Necmettin Erbakan, are locally organized under the umbrella of "Nederlandse Islamitische Federatie," the Dutch Islamic Federation which was formed in 1981. Around thirty mosques are attached to the Milli Gorus in Holland. Just like the Suleymanci movement, the Milli Gorus does not employ the imams paid by the Turkish Government (Nielsen 2004).

The followers of Said Nursi, who is known as Nurcular in Turkish, have their own mosque and study center in Rotterdam. The Nurcular, who have six mosques, have their main following among Kurds rather than Turks. They maintain good relations with the church of St. Paul and participate regularly in meetings for dialogue. They base their teachings on the Risale-i Nur, a limited Quran exegesis that consists of elaborated examples aiming at strengthening the certainty of belief (Shadid 1992).

An unknown number of Turks in the Netherlands are Alawis. They have a mosque in The Hague and about thirty local associations. The Turkish Islamic Cultural Federation, the Islamic Center in the Netherlands, the Dutch Islamic Federation (NIF), the Turkish Labor Union in the Netherlands (HTIB), the Union of Turkish Women in the Netherlands (HTKB), and the Federation of Democratic Social Associations in the Netherlands (DSDF) are all represented in the advisory council for Turks. The council may advise the Dutch Government on request or on their own initiative (Shadid 1992).

The Moroccon community is less well organized than the Turkish. The Union of 
Moroccon Muslim Organizations (UMMON) which was founded in 1978 is an umbrella organization representing eighty mosques. Despite UMMON's statement that it takes a neutral position on political matters, it is identified with the Moroccon monarchy. However, the mosques associated with UMMON have to employ their own imams as they are not supplied by Morocco. A number of Moroccon mosques exists independently of the UMMON and prefer to keep their distance from the monarchy. This tendency of "free" mosques is supported by the left-wing Committee of Moroccon Workers in the Netherlands (KMAN) (Nielsen 2004: 65).

The Moluccan Muslim community in Holland has no umbrella organization. They are the smallest Muslim community in Holland. In 1956, they opened their first mosque in the north of the country. They were resettled near Rotterdam and constructed two mosques. The construction of these mosques were subsidized by the Dutch Government as part of an agreement between Holland and the Moluccan community, which represents a recognition of the Moluccan's support for the Dutch during the Indonesian struggle for independence (Nielsen 2004: 66).

The Muslim community from Surinam is ethnically and religiously quite diverse. They consist of Hindustani (Sunnites as well as members of the Ahmadiyyah) and Javanese (Sunnites). The Javanese Sunnites have unofficial prayer-halls and have not been united under one umbrella organization. The Hindustani Sunnites have two competitive organizations at a national level: the World Islamic Mission (WIM) in Amsterdam and Internationale Moslim Organisatie (IMO). Hindustani Muslims who are attached to the Ahmadiyya movement are divided into two umbrella organizations: the 
Ahmadiyya Anjuman Isha'at Islam in Nederland (AAIIN) and the Ahmadiyyahbeweging in de Islam (The Ahmadiyyah movement in Islam) (Shadid 1992).

\subsubsection{Turkey as Administrator of Islam in the Netherlands}

The Islamitische Stichting Nederland (Netherlands Islamic Foundation) is an organization founded in 1982 in The Hague and directly linked to the Turkish Directorate of Religious Affairs (Diyanet) in Ankara. It organizes the religious life of Turkish Muslims in Holland since 1982. It has about 70 imams stationed in Holland. They are given residence contracts of four years duration. The Islamitische Stichting Nederland (ISN) states that its main aim is to protect and develop the conditions that are necessary for the Muslims to practice their religious duties within the Dutch community, provide social, cultural and educational services to the Turkish immigrants and serve as a bridge between the Dutch and the Turkish communities (ISN official website). They organize conferences, seminars and various other events to accomplish these goals. ISN's administration is handled by a Board of Directors whose members are elected for a twoyear period.

ISN not only provides religious services such as Qur'an courses for women and children but also provides a social forum for the Turkish immigrant community where they can discuss their problems and offer solutions to common concerns. According to an ISN official who asked to remain anonymous, their link to the Turkish Directorate of Religious Affairs (Diyanet) in Ankara is not as strong as the DITIB in Germany. He states that Turkey has always been more concerned about the radicalization tendencies among the Turkish community of Germany than that of the Netherlands. Therefore, the 
Turkish government officials have had a more relaxed approach toward the Islamic organizations in the Netherlands. He continues:

We embrace all segments of the Turkish Muslim community. Members of different Islamist movements such as Milli Gorus, Nurcular, Suleymancilar attend our events, they pray in our mosques. Despite the different names under which we are organized, in our hearts we all know that we were created by the same God. Of course relatively autonomous character of ISN is an important factor in this cooperation. In Germany, the monopoly of Turkish state on the administration of DITIB creates tensions within the community, fragmenting them into different movements (Interview, June 3, 2005, The Hague, Netherlands).

\subsubsection{Islamic Education in the Netherlands}

In the Netherlands there was an active political debate over education in schools beginning in the middle of the $19^{\text {th }}$ century. This battle, known as the "school struggle" (schoolstrijd), has its roots in the education law of 1857. This law was introduced as a revision to the Constitution of 1848 . It was based on freedom of education and the guarantee of primary education by the state, and promoted neutrality in education by emphasizing the need to exclude religious education from the education system. In 1878 , the law was revised by the liberals who put harsher restrictions on the standards of construction and facilities of denominational schools. When religious factions gained a majority in parliament in 1888, the coalition government revised the 1917 Constitution, which provided for full government funding for both neutral and denominational schools and guaranteed the same standards of construction and facilities as other schools (Mihara 2004: 5). 
There are two types of schools in Dutch school system: private schools (bijzondere scholen), the vast majority of which are Christian schools based on Holland's historical religious traditions, and public schools (openbare scholen), which are organized by local governments and have no specific religious character. The Islamic schools fall into the category of private schools (Mihara 2004).

According to the Constitution, parents have the right to establish private schools. If more than a certain number of parents wish for their children to get primary and secondary education based on specific beliefs, and conditions meet the guidelines legislated by law, they can establish schools and receive full funding from the government. Specific requirements such as the number of annual classes and academic achievement standards are prescribed by the government and the students in the final grade are required to take a nationally-standardized test, called the "Cito Test". Since there is no difference in the economic and social positions of both public and private schools, parents can choose to have their children attend either type at no cost (Mihara 2004: 6).

Due to the increasing concerns of Muslim parents, a number of Islamic schools have been established in Holland. These concerns include: increasing drop out rates among Muslim children in conventional Dutch schools because of lack of respect for differences in religion and the problems in communication and mutual understanding between schools and parents. The Islamic schools provide an environment both for Muslim children and their parents where positive self-awareness and emotional stability can be fostered. These schools are fully subsidized by the Dutch government and organized based on Islamic ideas in the framework of the Dutch school system. In 2005, 
there were 39 Islamic primary schools and two Islamic secondary schools in Holland (Mihara 2004: 2).

Organization of Islamic School Boards (Islamitisch Scholen Besturen Organisatie) is the representative organization for negotiations concerning Islamic schools at the national level. Each Islamic school selects one representative as a member of the "governing council" of the ISBO. In each school under the ISBO, there are several "administrators" (het Bestuur) who make policy decisions in accordance with the regulations of the ISBO. However, the administrators cannot make decisions by themselves. They are subject to the supervision of the "participation council" (de Medezeggenschapsraad: MR), which consists of several staff members and parents of students. Before making a decision, the administrators have to have the consent of the MR. The curriculum includes education in arithmetic, physics and other basic subjects. All classes are in Dutch and mastery of the Dutch language is considered the highest priority by the school authorities. They devote one or two hours a week to education in Islam and prayer (Mihara 2004).

Islamic schools are the result of the demand of Muslim parents and the Dutch school education structure which allows for the ethnic minorities to establish their own educational institutions in accordance with their beliefs and values. They have been founded and run under democratic principles. What function do these schools have within Dutch society? Based on the analysis of their administrative structure, education policies, educational content and the statements made by Muslim parents who send their children to these schools, four conclusions can be reached. 
First, Islamic schools create an environment where Islam becomes a source of a positive identity. Muslim children do not feel alienated because of their customs or their religious practices nor do they lose their cultural identity. By making Islamic cultural elements a source of an emotional support, Islamic schools play an important role in protecting Muslim children. Second, by respecting parents' opinions and children's feelings, these schools serve as a bridge between generations. Third, the quality of the education and the effort toward the acquisition of the Dutch language provides Muslim children the academic skills that would allow them more opportunities in Dutch society making upward mobility possible (Mihara 2004). Fourth, by providing proper Islamic education, Islamic schools integrate Islamic education into the Dutch school system and end the monopoly of the Islamist movements on Qur'an education. While in Germany where Islamic education is not offered in schools some radical groups attract followers by providing religious instruction, in the Netherlands Muslim children get Qur'an education from Muslim teachers under the guidance of the Dutch school system.

The phenomenon of Islamic schools is not an attempt by Muslims to isolate themselves from society. Islamic schools consider their own existence as part of the Dutch society. The Islamic school phenomenon arises from the Dutch "pillarization system" and serves the interests of both the Muslim community and the Dutch society.

\subsection{CONCLUSION}

Germany's exclusionist policy toward immigrants and its non-recognition of Islam as a religious community have created a marginalized Turkish immigrant community which lacks citizenship rights despite its presence in the country for four decades. Lacking the right to participate in the political decision-making process and in 
the face of perceived discrimination by the German society, the Turks turned to Islam and Islamist movements to voice their alienation and marginalization in a society where their beliefs and values are not respected and regarded as alien. Mosques have become social spaces where they can gather around a sense of common destiny and build a positive identity and self-awareness for themselves and their children. The 1970s' women in miniskirts became women wearing veils in 1990s, symbolizing the closing of not only their physical existence to the outside world but also their minds and souls.

The Dutch multi-cultural approach, on the other hand, has produced quite different social, political and economic results. Due to the existence of dual nationality right, majority of the Turkish immigrants acquired Dutch citizenship making them full participants of the political community. The right to establish Islamic schools took the monopoly in Islamic instruction away from the hands of the Islamist movements and granted them to schools that are fully funded by the Dutch government and run under democratic principles. The high quality education provided in Islamic schools makes upward mobility possible for the Turkish immigrants. The statements of Nurdan, who has been in the Netherlands for 17 years, articulate the prevailing mindset among the Turkish community living in the Netherlands and prove those who argue about the death of Dutch multiculturalism wrong:

I am a Dutch citizen. Of course I follow Dutch politics more than Turkish politics. It is the decisions of the Dutch government, not Turkish, that affect my and my family's life. I vote and I tell my Turkish friends to do the same. This is our home, this is a country that opened its arms to us and treated us as if we had always been here (Interview with Nurdan, 22 May 2005). 


\section{CHAPTER 4}

\section{METHODOLOGY}

\subsection{THE STUDY OF RELIGION: A CONTESTED SITE}

The question of whether religion can be studied scientifically has been at the center of the debate on the study of religion. The science of religion which has recently emerged as an autonomous discipline was divided into two parts by P.D. Chantepie de la Saussaye (1891). According to Chantepie the first branch treats the subject according to its essence and the second treats the subject according to its manifestations. The essentialist school looks at the study of religion from a theological standpoint and argues that the study of religion should primarily be concerned with the study of the sacred. This assumption has crucial implications not only for the subject of the study of religion but also for the methodology it applies. The essentialist school uses revelation to understand religion and religious movements.

One of the leading figures of this school is Karl Barth. His definition of religion is an important indicator of his understanding of religion. He states that

God's revelation in the outpouring of the Holy Spirit is the judging but also reconciling presence of God in the world of human religion, that is, in the realm of attempts by man to justify and sanctify himself before a willfully and arbitrarily constructed image of God. The church, insofar as it lives by grace through grace, is the locus of true religion (Barth in Green 1995: 477).

Based on this theological definition of religion Barth builds his approach to the study of religion. To him the study of religion should be the study of God instead of the study of humanity (Fiorenza 2000:11). Similar concerns were raised by Johann Baptist 
Metz and Ronald Thiemann. They both argue that the study of religion should primarily be the study of the sacred (Fiorenza 2000:11).

Contrary to the theological understanding of religion and the study of religion expressed by the essentialist school, scholars such as W.B. Kristensen, Friedrich Schleiermacher, Mircea Eliade and Gerardus van der Leeuw treat the subject not according to its essence but according to its manifestations. They all indicate that the right tool to understand religion and religious phenomena is not revelation but the perceptions and behaviors of those who believe in that religion. Religion can be the subject of academic inquiry only in terms of its manifestations. What should be studied to grasp a clear understanding of religious phenomena is not revelation but the phenomenon itself which is revealed in human perceptions of religion. This secular break from the traditional essentialist school of thought has crucial implications for the study of religion. It is a shift from the religious study of religion to the academic study of religion which requires the use of new techniques to address the religious phenomenon.

W.B. Kristensen is one of the most influential figures of this school of thought. According to Kristensen in order to understand religious phenomenon one has to see it through the eyes of the believer. What is crucial in this process is to understand the believers as they understood themselves, which requires the scholar of religion adopt the believers' point of view and let them speak for themselves. Kristensen states:

As long as he (the scholar) cannot enter into the subject and make the point of view of the people he is studying his own, his description will not succeed. He must be able to give himself to the other and to unselfishly forget himself; only 
then is there hope that history will open itself to him and that he will conceive the data in their proper significance (Plantinga 1989: 176).

What is important then for the study of religion is to understand the believers of a given religion. To Kristensen there is no reality other than the perceptions of the believers for the study of religion. He writes:

If we want to learn to know them (historical religions) as the believers themselves conceived and judged them, we must first attempt to understand their own evaluation of their own religion...Let us not forget that there exists no other religious reality than the faith of the believers. If we want to learn to know genuine religion, we are exclusively assigned to the expressions of the believers. What we think from our standpoint about the essence or value of other religions bears witness to our own faith, to our own conception of religious belief, but if our opinion about another religion deviates from the opinion and the evaluation of the believer himself, then we are no longer dealing with their religion...but we are exclusively concerned with ourselves (Plantinga 1989: 178).

Similarly, Friedrich Schleiermacher focuses on the importance of human experience in understanding religious phenomenon (Fiorenza 2000: 14). In the foreword to Patterns in Comparative Religion, Mircea Eliade summarizes this view with the following words: "Obviously, there are no purely religious phenomena...Because religion is human it must for that very reason be something social, something linguistic, something economic- you cannot think of man apart from language and society" (Eliade 1958: xiii). Gerardus van der Leeuw also stands in the tradition of scholarship of the above scholars in undertaking a phenomenology of religion. Phenomenology is defined 
as "the systematic discussion of what appears" by van Der Leeuw. Religion, however, is an ultimate experience that evades our observation so how can we even talk about phenomenology of religion? According to Van der Leeuw religion can be understood in two ways: from experience or from revelation. Revelation is not a phenomenon and it does not become experienced. "Theology" says Van der Leeuw, "speaks about God Himself" whereas phenomenology of religion does not. For phenomenology, "God is neither subject nor object; to be either of these He would have to be a phenomenon- that is, He would have to appear. But He does not appear; at least not so that we can comprehend and speak about Him. If He does appear He does so in a totally different manner, which results not in intelligible utterance, but in proclamation; and it is with this that theology has to deal" (James 1985: 329). According to Van der Leeuw, what appears in the field of religion is not revelation but the reflection of that revelation in human experience. Only through the perceptions, gestures and work of human beings can we understand the religious phenomenon (James 1985: 329).

This study adopts the latter perspective and argues that in order to understand religious phenomenon one has to understand how religion is perceived and experienced by the believer. Religion can become a matter of inquiry for social sciences only in terms of its reflection in human behavior. The use of a survey that is designed to measure the perceptions of the believer rather than his/her objective conditions such as his/her employment status or living conditions is therefore an effective tool to understand and explain religious phenomenon. However, a religious phenomenon is a complex phenomenon which requires tapping from a variety of cultural resources and therefore the use of a combination of quantitative and qualitative methods. As articulated by Russell 
Bernard, "a sound mix of qualitative and quantitative data is inevitable in any study of human thought and behavior" (Bernard 1995: 1). While using surveys is one major mode of gathering quantitative data, participant observation and interviewing are the main tools of qualitative method. After a thorough consideration of several research techniques, survey technique, extensive participant observation and long interview were chosen as the main tools to gather data in this study.

\subsection{RESEARCH DESIGN}

There has not been an agreement on the categorization of the different methods used in religious studies. Peter Berger has used the terms "Functional and Substantive", Robert Wuthnow has used the terms "Dualistic and Wholistic", Robert Segal has employed the terms "Reductionistic and Nonreductionistic" (Kepnes 1986: 504). The application of these two different sets of terms reflects the division in the bigger picture of the methodological debate between the quantitative and the qualitative methods. Paul Ricoeur offers two alternative terms to this methodological debate. The terms were taken from Wilhelm Dilthey to organize the methods used in religious studies: verstehen (understanding) and erklaren (explanation). According to Peter Berger, who is a leading contemporary advocate of the "understanding" approach, "the human world is essentially a network of meanings and, therefore, nothing in this world can be adequately understood without understanding these meanings from within" (Kepnes: 1986: 506). "Understanding" is only possible through the application of qualitative methods while "explanation" which takes the method of natural sciences as a model requires the application of quantitative methods. According to Ricoeur, the study of religion does not have to be 
either a scientific attempt to explain religious phenomena in terms of sociology, psychology or physics, or an intuitive and analogical attempt to grasp the meaning of religion from the believer's standpoint. The study of religion involves us in an act of interpretation which necessarily requires both methods (Kepnes 1986: 505).

Both the quantitative and the qualitative methods were utilized in this study. Surveys and long interviews were conducted in both countries and participant observation provided a useful tool to experience the reality of the informants.

\subsubsection{Surveys}

Surveys are the best tools to gather data for studies that deal with values and attitudes of individuals (Turner 1995). As Bachtrom and Hursh-Cesar argue the surveys will remain one of the best means of describing values until we find another way of getting the same information without talking to people (Bachtrom, Hursh-Cesar 1981: 5). They can be evaluated and replicated (Backstrom, Hursh-Cesar 1981). If the samples are large and random, you can generalize the results to the population at large.

Surveys also have disadvantages. Some critiques of surveys argue that surveys measure self-reported perceptions instead of reality. They can have errors because the process is performed by human beings (the researcher, the respondents) (Backstrom, Hursh-Cesar 1981). Due to the problems of language and question wording or "the response effect in which respondents answering react to the context or order in which the question is being presented" the respondent might be untruthful (Dominguez 1996, Stark and Roberts 1996). There might also be selection biases either because the sample systematically excludes or include certain groups of people. The first concern that the surveys measure self-reported perceptions instead of reality does not pose a significant 
critique of the survey technique employed in this study since it is exactly those perceptions that this study is trying to reveal. It is the perceptions of the members of the Islamist group and the host society that shape the reality that these people are living in. Therefore it is crucial to get a grasp of these perceptions in understanding the dynamics of Islamism. Other types of errors can be minimized by testing questions in advance and by translating them back and forth to the language needed. The errors that are related to the selection bias can be minimized by having large, representative, random samples.

There are three methods of collecting survey questionnaire data: 1) personal, faceto-face interviews, 2) self-administered questionnaires, and 3) telephone interviews. Due to the nature of the study and the questions that were asked, personal, face-to-face interviews are used in this study.

Face-to-face administration of questionnaires offers some important advantages. They can be used with informants who could not otherwise provide information such as informants who are nonliterate, blind or very old. If a respondent does not understand a question, you can fill in and if you feel that the respondent does not answer a question fully you can probe for more complete data. Moreover, you can use several different data collection techniques with the same respondent in a face-to-face interview. You can use open-ended questions or you might hand the respondent a self-administered questionnaire booklet and offer help in case there are ambiguous items. This technique is particularly useful if you are dealing with sensitive questions in a face-to-face interview (Bernard 1995: 258). Asking questions about a delicate issue like religion to the members of an immigrant community makes it harder to conduct telephone interviews or selfadministered surveys. But personal interviews have their disadvantages as well. They are 
intrusive and reactive. It is hard to administer a survey without telling the respondent how you hope he/she will answer your questions. As the members of a vulnerable group, the members of the immigrant community might be unwilling to answer your questions when you directly confront them. They are also costly in time and money and usually require going back to the field more than once to get to know the respondents and earn their trust. While you can survey thousands of respondents with mailed and telephone surveys, the number of respondents whom you can contact personally is limited (Bernard 1995: 260). Despite the difficulties and the disadvantages of the face-to-face interviews, this technique proved to be the most useful tool in gathering quantitative data about the values and perceptions of an immigrant community.

\subsubsection{Questionnaire Design}

There are two sets of questions in the questionnaire. Most of the first set of questions were taken from the World Values Survey and adopted to the Turkish immigrant context. These are questions that were designed to measure the level of social marginalization. Social marginalization is defined as "an external social position, of isolation of the individual or groups, with a limited access to economical, political, educational and communicational resources of the community" (The law adopted by the Romanian Parliament in 28 February 2002, www.hurriyetim.com, November 25, 2004). The questions asked try to reveal how integrated the members of the immigrant group are to the social, economic and political structure of the host society. Questions from A1 to A21 give the respondents an opportunity to express their beliefs and perceptions regarding their place in the host society, whether they feel part of the society at the social, economic, political, educational and cultural level. 
Questions from A22 to A51 were designed to measure the level of radicalism. The main indicators for radicalism were borrowed from a report prepared by the Ministry of the Interior of the Dutch Government under the title of From Dawa to Jihad: The Various Threats from Radical Islam to the Democratic Legal Order (AIVD Report, December 2004). A person is considered radical if he/she has low level of tolerance for those that do not share his/her beliefs, if he/she is against multi-culturalism, the equality of men and women, if she/he has low level of trust in democracy, if she/he holds orthodox views of his/her religion, supports the idea of transforming the society radically instead of gradually with the help of reforms and if he/she is against the virtue of secularism. The questions in this section are designed to reveal where the respondents stand on these topics. Question A22 is designed to measure the level of tolerance, questions A32, A33 and A34 measure the respondent's belief about the equality of men and women, A35 and A36 deal with the respondent's attitude toward Western values, A37, A38, A39, A40, A41, A42, A43 and A44 measure how much faith the respondent has in democracy and democratic norms, A45, A46, A47, A48 measure whether the respondent is for or against secularism, A49 measure the level of puritanism by asking whether Qur'an can be interpreted according to the context. Although the words "puritanism" or "orthodoxy" were not used in the interview, variable A49 was named "puritanism" which was defined as "strictness and austerity especially in matters of religion" (Merriam-Webster's Dictionary). The word "othodox" has been used synonymously with the word "puritanical". When the term "orthodox" or "puritanical" is applied to the Turkish context, it becomes an important indicator of radicalism.A50 and A51 are the questions that reveal the respondents view about integration and a multi-cultural society. 


\subsubsection{Long Interviews}

The long interview method is usually employed to examine cultural constructs and allows the depiction of the native perspective (McCracken 1988). The long interview can be structured, semi-structured, or unstructured depending on the amount of control exercised by the researcher (Bernard 1994). Structured interviewing involves following a strictly uniform questionnaire. All the respondents are asked to respond to identical questions. An unstructured interview is the most widely used method of data collection in cultural anthropology. While it is based on a clear plan that the researcher keeps constantly in mind, it gives almost complete freedom to the informant. The idea is to let the informant express himself/herself in his/her own terms. Unstructured interviewing is used in situations where the researcher has lots of time. In situations where the researcher does not have that much time and chance to interview someone more than once, semistructured interviewing is the best (Bernard 1995, 209). It makes use of a questionnaire while permits variations in individual cases. The interviews can be open-ended or closeended. Close-ended questions use a set of available answers while open-ended questions give the respondent a chance to generate his/her own answers. The respondent is allowed to tell his/her story in his own terms. Semi-structured interviews work very well if you are dealing with the elite or bureaucrats- people who are accustomed to efficient use of their time. While you are fully in control of what you want from an interview, semistructured interviews give you and the respondent the freedom to follow new leads (Bernard 1995: 210).

The long interviews employed in this study are semi-structured and unstructured. Semi-structured and open-ended interviews were conducted with the elites of the Milli 
Gorus movement. While the respondent was allowed to tell his/her story in his/her own terms, the flow of data was controlled by means of a well-designed questionnaire which was constructed after series of informal and unstructured interviews. The use of a questionnaire as the main reference point in the interview not only keeps the contextual order the same for all informants but also allows the researcher to give full attention to the respondent.

Unstructured interviews were conducted with the members of the Milli Gorus movement. Most of them were interviewed informally in the mosques after the Friday prayers, in their houses or during the social gatherings such as weddings or charity meetings. All the informants were assured of anonymity and asked to express their feelings about the host society that they lived in and the reasons for their membership in the Milli Gorus movement. The researcher explained to them why their opinions were crucial for the study. Unstructured interviewing is very useful when dealing with sensitive topics and vulnerable communities. Given the objectives of this study, which deals with the perceptions of an immigrant Islamist community which is under constant scrutiny of the host governments, unstructured interviewing is the best since the majority of the informants would not tolerate a more formal interview. With the help of the unstructured interviews, the researcher was able to build initial rapport with informants before moving to more formal interviews and surveys.

\subsubsection{Participant Observation}

The survey technique and the long interview were supplemented by participant observation in this study. Participant observation or ethnographic fieldwork is the foundation of cultural anthropology. It involves getting close to people and making them 
feel comfortable with your presence which will allow you to observe and record information about their lives (Bernard 1995:136). While some participant observers advocate "going native" and "becoming the phenomenon", most researchers advocate maintaining some distance and objectivity (Bernard 1995: 137). Participant observation is useful in the production of detailed accounts of the participants' lives and provides the researcher with a deep understanding of the phenomenon. With Bernard's words "Whether your data consists of numbers or words, participant observation lets you in the door so you can do research" (Bernard 1995: 17). Participant observation, however, has some deficiencies as well. It is exposed to several threats to internal and external validity. Unmeasured and unobserved factors, varying test techniques, atypical or extreme participants, change in participants over time due to unrelated factors, nonrandom members or nonequivalent groups are among the threats to internal validity. It is claimed that the fact that participant observation renders its subjects into objects and leads to "othering" of the informants is the main threat to the external validity of participant observation. According to this view there are no objective observations. Observations are socially situated in the worlds of the observer and the observed. The subjectivity is enhanced by the tendency of the researcher to protect his/her informants (Knowles 2002) As argued by Levi-Strauss: "Unless ethnographers use methods other than just participant observation, they are unlikely to report the negative aspects of their subjects' personalities and lives" (Levi-Strauss, 1963).

Despite its deficiencies, participant observation is an excellent method to collect information especially when it comes to the examination of dynamic and multifaceted concepts such as the formation, preservation and radicalization of Islamic identity among 
an immigrant community in a Western European context. It is impossible to imagine a complete stranger walking into a local mosque and being welcomed to watch and record the religious rituals, especially in a post-September 11 context where Islamist groups are under increasing pressure by the European governments. What makes intrusive acts of data collection possible is participant observation (Bernard 1995: 141).

Second, participant observation reduces the problem of reactivity. As you develop closer relations with the participants, people take less and less interest in your comings and goings which increases the validity of data. Third, participant observation helps you formulate sensible questions. When you get familiar with the culture you are studying, you formulate better questions that will allow you get a better understanding of the phenomenon. It also gives you an intuitive understanding of the culture you are studying. With the help of the cultural facts that you have collected during participant observation, you can make strong statements about the culture. It extends both the internal and the external validity of what you learn from interviewing and watching people. Participant observation helps you understand the meaning of your observations (Bernard 1995: 141). It helps you collect both quantitative survey data and qualitative interview data. Qualitative and quantitative data inform each other and enhance the understanding of the phenomenon in ways that cannot be achieved by either approach alone. No matter what kind of data you are collecting, participant observation maximizes your chances for making valid statements (Bernard 1995: 142).

During participant observation the researcher is emotionally involved (participation) and personally detached (observation) at once. There are various types of participant observation depending on the degree of participation. Participation can be 
moderate and include participation in certain activities or it can be full which can be characterized as going native (Knowles 2002). The disadvantages of moderate observation employed by this study are offset by the fact that the researcher is a native herself. Participant observation can be direct-reactive or unobtrusive depending on the mode of observation. Unobtrusive participation, which does not require quantification of research indicators, is chosen as more appropriate for the verification of cultural statements (Knowles 2002).

\subsubsection{Population and Settings}

In order to assure heterogeneity of cases deliberate sampling is used. Sampling can be probability or non-probability. Non-probability sampling techniques such as snowball, random walks, purposive, and quota sampling are used to study small populations without a reliable sampling frame. Probability samples, such as random simple, systematic, stratified, disproportionate, and cluster, are highly recommended in social research since they are representative of the larger population and increase external validity (Knowles 2002). Non-probability samples have low external validity but they can be highly reliable when supported by ethnographic testimony (Bernard 1995: 94). Snowball sampling is popular in community studies. The process is to locate one or more key individuals and obtain the name of others who would be willing to participate in the research (Bernard 1995: 97). Snowball sampling is very useful in studies of small, bounded, or difficult to find populations (Bernard 1995: 96). Given the subject matter of this study which is a migrant community from a particular religious group, snowball sampling is a very useful tool for exploratory research. This technique yielded a total of 
85 potential participants. Based on the potential pool of participants, 76 percent of them agreed to participate in the study.

A few informants are capable of providing adequate information about a culture or a population. According to Bernard (1995: 165), the key is to select knowledgeable informants. In order to achieve this aim, the researcher has to take several issues into consideration: the heterogeneity of the population; the number of groups included; the desired accuracy; the size of the phenomenon to be examined' and the money and time available for the project. The goal was to select informants from Cologne and Amsterdam who not only had close relations with the Milli Gorus community but also was a trusted and well-respected member of the Turkish immigrant community. As a precursor to the actual study, in summer 2005, the researcher began to lay the foundation for this research. It was within this context that the researcher began to identify potential participants for the actual study. Due to the sensitive nature of the subject matter, the researcher took few months in the summer of 2005 and 2006 to build relations with the Turkish community in Cologne and Amsterdam in general without focusing on the Milli Gorus community specifically. After establishing a small network of individuals who had close ties with the Milli Gorus community, the researcher could be able to attend the social gatherings and meetings of the Milli Gorus community to collect data by means of surveys and long interviews. At the end of each interview, the informant was asked to name other members of the community who would be willing to participate in the research. Many of the informants were interviewed either at their houses or during their social gatherings such as weddings or funerals. Considering the closed nature of the Milli Gorus community, this could only be possible with the help of a Turkish theologian 
whom the researcher met in the summer of 2006. Many of the informants mentioned that they would not be willing to answer any questions regarding their religion if the researcher was not accompanied by the well-respected Turkish theolog who had close ties both with the Milli Gorus community in particular and the Turkish community in general.

Snowball sampling is supported with cluster sampling in this study. Cluster sampling is a way to sample populations for which there are no convenient sampling frames (Bernard 1995: 89). Due to the lack of a convenient sampling frame, a three-stage sampling design is called for. In the first stage, a list of the Milli Gorus mosques was made. The names and the addresses of the mosques that belong to Milli Gorus movement in Germany and the Netherlands were acquired from the webpage of Milli Gorus. The sample cases were drawn from Cologne and the neighboring cities in Germany and Amsterdam and the neighboring cities in the Netherlands. Atypical setting is listed as one of the major threats to external validity in qualitative research, besides non-random selection of cases (Knowles 2002). In terms of Milli Gorus community, are Cologne and Amsterdam essentially different from other cities in Germany and the Netherlands? Cologne and Amsterdam are the two cities where Milli Gorus Headquarters are located. In terms of the socio-economic or religious profile of the members of Milli Gorus there are no studies indicating these two cities are different from other cities to the knowledge of the researcher. Therefore, the sample of Milli Gorus community in Cologne and Amsterdam can be used to represent the entire population of Milli Gorus community in these two countries.

In the second-stage, the researcher made a list of Milli Gorus mosques that are around Cologne and Amsterdam. Finally, in the third stage of the design, the surveys 
were distributed randomly to the Milli Gorus members in these mosques. Considering the likelihood of people who do not identify themselves with Milli Gorus movement but still attends the prayers in these mosques, a question asking the respondents whether they identify themselves with Milli Gorus movement or not was added to the survey. According to Bernard (1995: 91), the main rule in sampling is to maximize heterogeneity. In order to accomplish this goal, the researcher distributed maximum 15 surveys in each mosque.

\subsubsection{Data Collection}

Fifty six long interviews with Milli Gorus members in Germany and the Netherlands were conducted between May 2005 and May 2007. The interviews lasted between one to three hours. Due to the delicate nature of the subject matter being studied, the researcher was accompanied by a local, well-respected member of the Milli Gorus community in both countries during the interviews. The interviews took place mostly in the houses of the informants, in the mosques or during the social gatherings such as weddings or charity events. The open-ended interviews included questions about the informant's experiences and feelings about the host society and their general views about democratic norms, social change, secularism and women's rights. Attention was paid to sequencing of the questions. After several participant observations, the researcher realized that starting the conversation with the questions about democracy, religion and secularism created reluctance on the part of the informant to continue the interview. Therefore, more neutral questions such as their trip to Germany or the Netherlands as quest workers were used to start the interview. This not only created an amiable atmosphere but also revealed necessary information about the social, economic and 
emotional background of the informant. After the completion of the first step, the researcher moved on to more specific questions about the feelings and experiences of the informant regarding the host society and his/her views about democracy, secularism, women's rights, social transformation and the Western world. The same interview procedure was applied in all interviews. The researcher opened with appropriate questions and gave the respondent plenty of room to talk. Depending on the circumstances patient waiting or probe insertion were used to handle silence. Dialogue and abrupt changes were avoided.

Long interviews material was supplemented by conversational interviews. The researcher engaged in casual conversations with the respondents, asking them questions about their concerns. Most of the interviews were conducted in the mosques and in the homes of the informants which gave opportunity for supplemental participant observation. Participant observation was used to reduce possible self-report bias. Location, people and events were observed. The observations were carried out during reunions of large numbers of Milli Gorus members. According to Johnson and Sackett (1998) the ideal "observation window" is 24 hours. This ideal option was employed during the researcher's overnight stays in the homes of the Milli Gorus members.

Two different patterns of interaction were detected for the German and the Dutch Milli Gorus. The Milli Gorus members located in the Netherlands were more open to interaction with strangers. The Milli Gorus members living in Germany were more conservative in their approach to others and in talking about their religion or topics such as secularism with strangers. The researcher experienced difficulty in distributing the surveys in some of the mosques in Cologne, Germany. She attempted to distribute the 
surveys right after the Friday prayer but encountered objections from the Milli Gorus members. One of them voiced his concern that participation in the study would harm the Milli Gorus community:

You come here and ask questions about our religion and these things get published. The next day the German police knock on our door blaming us for being radicals. We have suffered enough for being Muslims in this country; we don't want any more trouble.

With one exception, the distribution of surveys in the mosques went smoothly in the Netherlands. Field notes were taken to document participant observation sessions, conversational interviews and events accompanying the long interviews in all occasions of observation and interviewing. In some cases the notes were taken right after the interview since note taking impact the participant observation by reminding the informants that they are being observed. In other cases where the informants felt comfortable with the researcher taking notes, the notes were taken during the conversation. Analytic ideas, personal impressions and feelings and notes for further information comprised the researcher's field notes.

\subsection{DATA ANALYSIS}

\subsubsection{Qualitative Data Analysis}

As articulated in the introductory chapter, religion can be a topic of scientific inquiry only due to the human dimension it has. How human beings perceive and experience religion is the only dimension that can be of interest to the social scientist. Therefore, in the attempt to understand the Islamist movements, the scholar should focus on the experience of the believer. As articulated by Schleiermacher, the only way of 
understanding religion is through an understanding of the full historical identity of the particular religious faith (Fiorenza 2000, 9). This type of understanding not only requires understanding the perceptions and experiences of the believer but also the context which gives rise to this experience.

In order to understand Islamist movements, Martin Heidegger's phenomenological method provides a useful tool. This method is valuable in the study of religion because it gives priority to human experience in understanding phenomenon, religious phenomenon in particular. Adopting Heidegger's point of view in understanding religious phenomenon requires presenting qualitative data that was collected through participant observation and long interviews. Qualitative data analysis depends heavily on the presentation of anecdotes and comments from informants. Although this technique looks easy one has to avoid what Lofland (1971) called the two great sins of qualitative analysis (Bernard 1995: 363).

The first $\sin$ is excessive analysis. If you analyze data and conclude that something simple is going on, the researcher should not hesitate to say so. The second sin consists of avoiding doing any analysis. Writing pages of quotes from the informants without making any analysis is as dangerous as doing excessive analysis. The researcher has to develop her/his own ideas and analysis about what is going on and illustrate them with selected quotes from the informants (Lofland 1971 in Bernard 1995:363). The researcher of this study used the informant quote technique widely to get a clear understanding of the meaning of Islamism and religious experience from the point of view of the informant. 


\subsubsection{Quantitative Data Analysis}

The two cases will be compared by using a simple t-test. The t-test assesses whether the means of two groups are statistically different from each other. This analysis is useful whenever you want to compare the means of two groups.

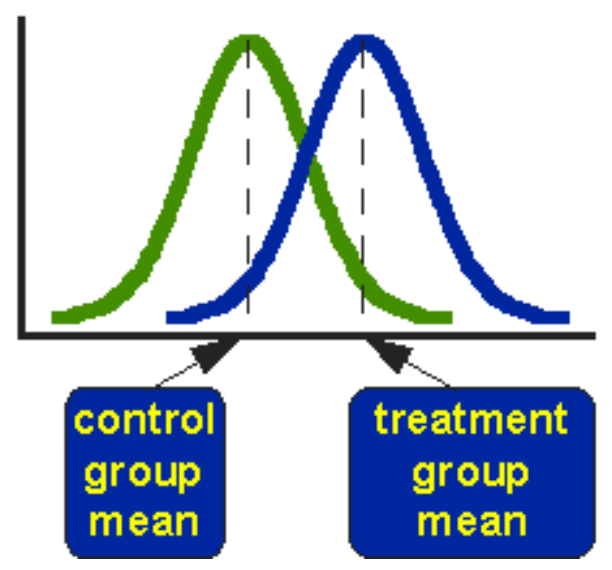

Figure 4. 1 Idealized distributions for treated and comparison group posttest values

Figure 4.1 shows the idealized distributions for the treated and the control groups in a study. The t-test answers the question whether the means are statistically different. If we look at the figures in Figure 4.2, the first thing that will be noticed is that the difference between the means is the same in all three. But these figures do not look the same and they tell different stories. The top figure shows a case with moderate variability of scores within each group. The second case shows the high variability case whereas the third shows the case with low variability. It can be concluded that the two groups look most different in the low variability case because there is little overlap between the two bell-shaped curves. In the high variability case the group difference is low because the two bell-shaped distributions overlap so much. 


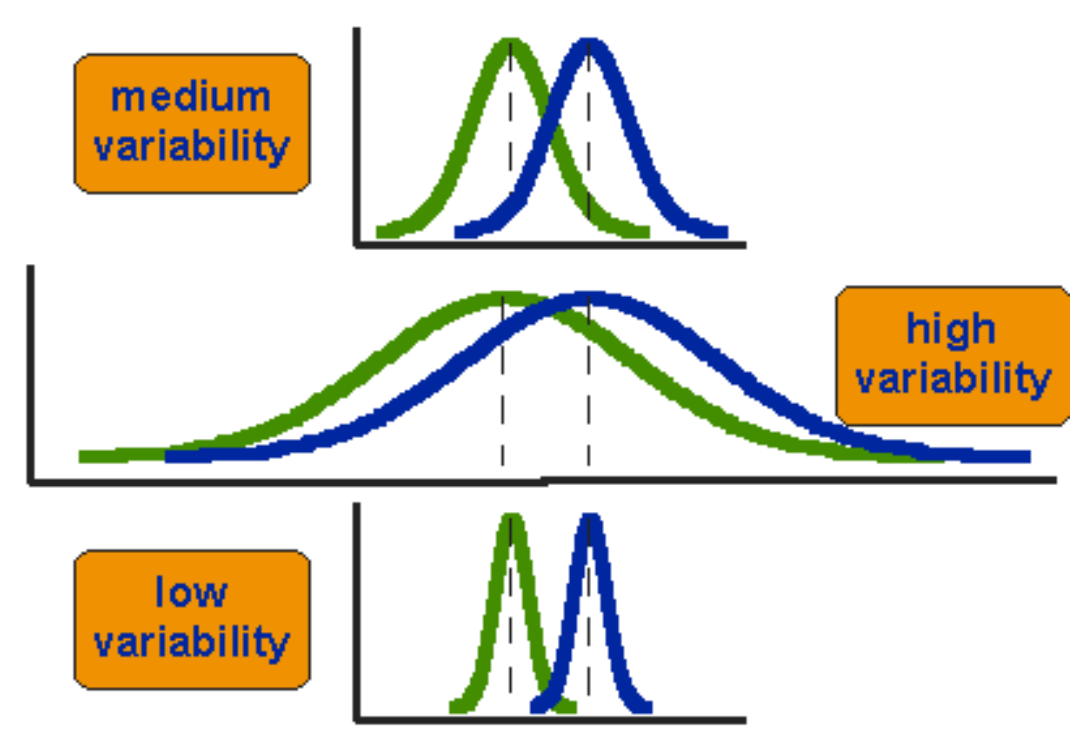

Figure 4. 2 Three scenarios for differences between means (figures were taken from www.socialresearchmethods.net)

This leads us to the conclusion that when we are comparing two groups we have to look at the differences between scores for two groups and judge the difference between their means relative to the variability of their scores. The t-test does this. The difference between the means of the German case and the Dutch case was compared by using the $\mathrm{t}$ test.

\subsection{ETHICS}

Scientific research cannot ignore ethical concerns even when more efficient data collection is offered in the absence of these concerns. It is the responsibility of the researcher to protect the informants. In order to protect the informants and their communities, the researcher has to respect the confidentiality of the data, anonymity and participant's informed consent. Informed consent is "knowing consent of an individual, or a legally authorized representative, able to exercise free power of choice without undue inducement or any element of force, fraud, deceit, duress, or other forms of constraint or coercion: (Rules and Regulations, Federal Register, Fluehr- Lobban in 
Knowles 2002). However, informed consent without forms is being used more often in the social science research. Since it was already hard for the informants to talk about their religion and their experiences in the host society, the researcher of this study obtained the informant consent of each participant before the administration of long interviews without the forms.

In order to protect the anonymity of the informants, the majority of the names of people were given fictitious names. The names of the cities were kept due to the methodological significance of the setting. The researcher paid special attention to maintain the informant's awareness of being researched before taping the interviews. The informants were also assured that once collected and analyzed the data will not be used for other than scientific purposes. Due to the highly sensitive nature of the data, special attention was given to restrict access of anyone besides the researcher to tapes or transcribed interviews.

Ethics poses the problem of the researcher's participation. Some researchers choose to follow the principle of non-participation while others refuse to remain observers and argue that they are co-participants with their informants (Knowles 2002:43). Good, for instance, witnessed a rape while he was conducting research and did not do anything about it not to take sides and make value judgments (Good, 1991: 102103 in Knowles 2002). Other researchers refuse to remain non-participants. Nash, for instance, was actively involved in the struggle of tin miners in Bolivia and their fight (1976 in Knowles 2002) Most of the researchers choose to remain somewhat between these two extremes. 
Although sharing the same ethnic and religious background with the informants provides valuable insight into the subject matter being studied to the researcher, it requires additional effort on the part of the researcher to distance herself from the subject matter and not to take sides and make value judgments. All efforts were made on the part of the researcher to see the phenomenon being studied from the eye of the informants and let the data shape the analysis of the researcher. Despite the efficiency it would provide, the researcher did not pretend to be one of the Milli Gorus members. Although she attended the prayers and prayed with them, she made sure that the informants were aware of the fact that the researcher was there to study the Milli Gorus movement.

\subsection{STUDY LIMITATIONS}

Internal validity is very crucial for this study given the fact that it deals with cultural translations of prescribed values. Validity means response validity, data accuracy and the accuracy of drawn conclusions and offered interpretation (Zelditch 1969: 9). The researcher observed some changes in the opinions and values of some of the respondents during the three year process of field research. One of the previous respondents in Amsterdam who scored low on the radicalism scale changed his moderate rhetoric completely at a later interview. While he considered Holland as his home when he was interviewed in 2005, he argued that he did not feel that he was part of the Dutch society and he considered Turkey as his home. He also became more critical of the Western type democracy and more in favor of a society that was governed by religious rules. This change in values might be explained by the increasing social and political pressure on the immigrant societies of Europe after September $11^{\text {th }}$, further research has to be conducted in order to explain this change empirically. 
In seeking to attain external validity, the researcher relied on the construction of a three-stage cluster sampling design. However, non-probability sampling techniques such as snowball sampling were used extensively in this study, which decreases external validity. In order to increase external validity, more cases should be included into the study.

Informants' self report bias is one of the most common concerns raised against the interview and survey techniques. Some researchers argue that human beings are not capable of describing and explaining their own behavior (Bernard 1994 in Knowles 2002). All efforts were made on the part of the researcher to test implicit views and prevent the informant from deliberately distorting in order to protect his/her self-interest. Participant observation was employed to supplement interview data and verification of verbal statements. Translation of documents from Turkish into English could have caused loss of information and decreased internal validity. In dealing with this problem, I relied on my linguistic and cultural knowledge of the English language. 


\section{CHAPTER 5}

IGMG IN GERMANY AND THE NETHERLANDS: ORGANISATIONAL STRUCTURE AND VIEWS

Islamic Community Milli Gorus (IGMG) or, as it is more generally known, Milli Gorus is an Islamist organization of Turkish immigrants in Europe. The headquarters are in Cologne, Germany but the organization has several regional organizations in other European countries. The IGMG has four regional organizations in France (Paris, Strasbourg, Lyon, Annecy), two in Austria (Austria 1 and Austria 2), four in the Netherlands (two in the northern and two in the southern part of the Netherlands). In Switzerland, Italy, Norway, Sweden, Denmark, Belgium and England, it is represented by one national organization each (official Milli Gorus website).

Milli Gorus is the name of an ideological current which initially materialized in Turkey as a political party in 1969 when Necmettin Erbakan, the founder of the movement and its ideological inspiration formed Milli Nizam Partisi (National Order Party). Starting from the 1970 s the movement spread among the Turkish immigrant community in Western Europe (Pedersen 1999).

Necmettin Erbakan built the Milli Gorus ideology around two concepts: Milli Gorus ("national view") and Adil Duzen (“just order"). In the manifesto that he published in 1975 , he focused on the importance of moral and religious education, industrialization, development and economic independence in establishing a "just order" where the rights of the disadvantaged and the oppressed were being protected. According to the Milli Gorus ideology, justice is crucial and closely tied to Islam and a strict Islamic order. Any political or social model that deviates from Islam is believed to be unjust and despotic. 
The Milli Gorus manifesto considered the Common Market to be a Zionist and Catholic project for the assimilation and de-Islamization of Turkey and warned against deepening relations between Turkey and Europe. It called for closer economic and political relations with Muslim countries. The name of Milli Gorus remained associated with a religiopolitical movement and series of Islamist parties inspired by Necmettin Erbakan. Erbakan's supporters in Turkey became members of the Saadet Partisi (SP, Felicity Party) after its predecessors Refah Partisi (RP, Islamist Welfare Party) and Fazilet Partisi (FP, Virtue Party) were banned for violating Turkey’s laic legislation (Bruinessen 2004). The ban of Fazilet Partisi (Virtue Party) resulted in the establishment of two parties: The Saadet Partisi (Felicity Party) which represented Erbakan's old guard and AK Party (the Justice and Development Party) which was led by younger generation and more pragmatic politicians under the leadership of Recep Tayyip Erdogan. The AK Party leadership claims to have renounced its Islamist roots. It has been ruling the country since the 2002 elections.

Milli Gorus became one of the most important religious movements among the Turkish immigrants in Western Europe. Right after the establishment of the movement in Turkey in 1969, it spread among the Turkish guest workers in different West European countries. By the name "Milli Gorus" the IGMG manifests its affiliation to the views and perceptions of the Abrahamitic community. Although the word "milli" comes from the word "millet" which means nation/people in Turkish, the IGMG traces the origin of the word back to the Qur'anic notion of "millet" which appears in association with the Prophet Abraham. According to Qur'an, the concept of "millet" means a community that gathers around a prophet and the values he conveys (Qur'an 2:130, 135; 4:125; 6:161; 
$12: 38 ; 22: 78)$. It does not refer to a nation or an ethnicity. The second part of the name Milli Gorus is "gorus" which means "opinion", "view" or "perception" in Turkish (official IGMG website).

The IGMG's interpretation of Islam is based on the teachings of the Qur'an and the Sunnah. Their principles and activities are guided by these two sources. By its own account, the IGMG

is an Islamic community which comprehensively organizes the religious lives of Muslims. The IGMG not only aims at maintaining the Islamic teachings, proclaiming the Islamic creed and communicating religious duties resulting from that proclamation. Other than that the IGMG addresses all issues regarding Muslims while at the same time representing their interests. It is the goal of the IGMG to improve the living circumstances of Muslims as well as to provide for their fundamental rights...the IGMG also carries out its duties supporting the socially disadvantaged and oppressed people of the world (official IGMG (Germany) website).

IGMG's institutionalization, public profile, and views show considerable differences from one country to the next, which suggests that the context of the host societies not only shape the interaction between the IGMG and the host society but also the rhetoric adopted by the movement. While discrimination and exclusion by the host society lead to feelings of insecurity, alienation and thus radicalization within IGMG in Germany, inclusive policies that are designed to incorporate immigrants in the host society have resulted in an IGMG that is optimistic and integrationist in its discourse in the Netherlands. 


\subsection{IGMG IN GERMANY}

\subsubsection{Historical Development of IGMG in Germany}

Within a year after the Milli Gorus movement was established by Necmettin Erbakan in 1969 in Turkey, the Milli Gorus ideology was already represented among migrant workers in Berlin under a union named "Turk Kultur ve Yardimlasma Dernegi" (Turkish Culture and Solidarity Union). Later the union assumed the name "Avrupa Turk Birligi" (The Turkish Union in Europe). In 1981 the organization appeared publicly in West Germany under the name Milli Gorus. In 1985 the name Milli Gorus was changed to Avrupa Milli Gorus Teskilatlari (Pedersen 1999, 58). It became Islam Toplumu Milli Gorus (Islamic Community Milli Gorus or Islamische Gemeinschaft Milli Gorus-IGMG) in 1995 and is currently organized under this name.

Metin Gur is a journalist who has several books and articles published in wellknown Turkish newspapers on Milli Gorus. He came to Germany in 1968 and has been living in Wuppertal, a city in North Rhine-Westphalia, Germany since then. According to him, Islamic identity was not strong among the first wave of immigrants who came to Germany right after the 1961 labor treaty signed between Germany and Turkey. The Turkish immigrant associations that were established at the time were not religious but social forums created to establish social support systems. The main purpose was to provide the new immigrants a place that they could socialize with their fellow countrymen and find strength in gathering around a common destiny (Interview with Metin Gur, 24 May, 2007).

With family reunification in the 1970 s, the profile of the Turkish immigrant community changed. The formerly male dominated community was joined by women 
and children. As a result new issues became important such as housing conditions, children entering public school system, places of worship for women, Islamic teaching for children. These needs were met neither by German authorities nor by Turkish government. Milli Gorus filled this vacuum by responding to these changing needs and became an important actor in the public life of Turkish immigrants (Interview with Mehmet Ocal, 18 May, 2006).

\subsubsection{Structure of IGMG in Germany}

Since Islam is not a recognized religious community in Germany, Milli Gorus, like all other Islamic organizations, organizes as "Eingetragende Vereine" (e.V.), or as associations. Depending on their respective tasks, the cultural, religious and social services of the Milli Gorus are offered either by the central administration or local communities. Local mosques which provide the necessary infrastructure such as praying rooms and imams constitute the smallest unit of Milli Gorus's religious activities. Women and youth departments also operate locally. They carry out activities for general purposes but primarily focus on the needs of each of their target groups.

Milli Gorus has local mosque communities in Germany, the Netherlands, Belgium, France, Switzerland, Austria, Italy, England, Denmark, Sweden, and Norway. The local communities are structurally bound together under regional organizations. There are 15 regional organizations in Germany which are in Hamburg, Bremen, Berlin, Hanover, Northern Ruhr Basin, Dusseldorf, Cologne, Hesse, Rhine-Saar, Stuttgart, Swabia, Freiburg, Northern and Southern Bavaria. The regional organisations constitute a linkage between the Milli Gorus centre and the associated local communities. They are 
responsible for the cooperation between local communities, coordination of religious and educational services and the imams and the arrangement of cultural events.

The central administration in Germany is responsible for the coordination of all religious, social, cultural and educational activities of the Milli Gorus community. It is the main body developing the general strategy of the organization regarding essential topics. The central organization undertakes the organization of hajj (pilgrimage to Mecca), the Udhiyyah campaign (sacrifice), prayer calendars, the solidarity fund of the burial services and assignment and training of imams, which cannot be carried out by the local or regional organizations.

Milli Gorus incorporates 514 mosque communities at the local level, 323 of which are in Germany. It maintains a total number of 1833 local facilities and has 87,000 members. By its own account, almost 300,000 people attend Milli Gorus's Friday Prayers (Milli Gorus official website). Milli Gorus is composed of 7 departments: Department of Education, Irshad (Religious Guidance) Department, General Secretariat, Department of Organisational Development, Women's Department, Youth Department and Department of Finances.

\subsubsection{Department of Education}

Department of Education is responsible for providing educational services such as religious instruction, homework tutoring, school and professional education. Although some of its activities are designed to help children in their school work, the majority of the activities carried out by the Education Department serve the purpose of increasing the level of religious consciousness through Islamic education, Europe wide competition of Qur'an reading and so on. Every year Milli Gorus Department of Education organizes a 
Europe wide competition among the Turkish youth in which the Islamic knowledge of the youngsters are tested via 45 multiple choice questions. This year's competition was held on April 27, 2008 and 95 young Turks between the ages of 13-25 from 20 regions attended the competition. The majority of the questions were designed to test the attendee's knowledge on Islamic faith but questions such as "Who is the current secretary general of the Organization of the Islamic Conference?" are asked in the annual competition (Milli Gorus's official website).

The Department of Education also designs curricula for Islamic education in Milli Gorus mosques. The Qur'an courses in Milli Gorus mosques are taught by imams who are trained by Milli Gorus General Secretariat in Cologne.

\subsubsection{Irshad (Religious Guidance) Department}

Milli Gorus considers religious guidance as its central duty. The Irshad Department provides religious assistance to Muslims. In Muslim countries, counseling on religious matters is provided through issuing fatwas by muftis, state-appointed religious authorities. Although it is possible for a mufti to issue a fatwa at his own initiative, fatwas are usually issued as a response to a request. In Western Europe, since there are no stateappointed muftis, religious guidance is provided by Islamist movements. Milli Gorus's Irshad Department responds to this need and serves the purpose of religious guidance within the Turkish immigrant community. The specific responsibilities of the Irshad Department include giving advice on daily prayers, congregational Friday prayers, religious holiday prayers such as Eidu'l-Fitr and Eidu'l-Adha, celebration of holy nights, collective fast breaking in the month of Ramadan and other religious rituals. The Irshad Department also organizes the annual pilgrimage to Mecca and Medina and helps with 
the performance of the Zakah, Fitrah and Sadaqah obligations (Milli Gorus official webpage)

The Irshad Department is also responsible for the training and education of the imams. A fiqh council within the department is in charge of interpreting the religious sources and of advising Muslims in terms of adapting Islamic faith to their every day lives (Milli Gorus official website).

\subsubsection{General Secretariat}

The General Secretariat is the main body that is responsible for organizing relations with the community and the central administration of Milli Gorus. The Legal Department functions within the General Secretariat and deals with cases of discrimination against Muslims. Its main aim is the protection of the fundamental rights of Muslims. The General Secretariat collects and documents the cases of discrimination that is brought before the Legal Department and informs the public via Milli Gorus's official website www.igmg.de, internet radio www.igmg.fm, the monthly journal IGMG Perspektive and quarterly culture magazine Sabah Ulkesi.

\subsubsection{Department of Organisational Development}

In the 1960s when Muslim guest-workers first came to Germany, they used storerooms of worker hostels and rented garages to perform their daily prayers. Then the so called "backyard mosques" were born when they started renting halls, workshops and abandoned industrial enterprises which were located in redevelopment areas of Germany's big cities. In the 1980s, the Turkish immigrant community started converting purchased estates into mosques but the process of building mosques was not without reactions from the German community and German authorities. Even today building of 
mosques incites controversies in Germany. The recent debate on attempts to build a mosque in Ehrenfeld, Cologne by Turkish immigrants is an example of the symbolic importance of the issue. Demonstrations against the building of the mosque in Ehrenfeld were held in Cologne. The main concern raised both by the German community and local German authorities is that the mosques symbolize the anti-integration tendencies of Turks. Local authorities state that the main purpose of Turks is not to build a mosque where they can perform their religious duties but to build it higher than the churches to prove their overwhelming existence in a Christian country (Interview with Halil Aydemir, June 12, 2007).

The Department of Organizational Development considers providing guidance in mosque building initiatives of the community as its main responsibility. It not only offers services such as formation and supervision of mosque communities but it also takes care of the formulation of a charter and aspects regarding fiscal law (Milli Gorus's official website).

\subsubsection{Women's Department}

The Women's Department offers tutorials and trainings for women. It organizes conferences on Islamic faith, the role of women in Islam, parenting, marriage and health.

\subsubsection{Youth Department}

The official page of the department starts with the statement that "the establishment of a steadfast identity is the only way to a successful integration of Muslim youngsters into society". By Milli Gorus's own account, the main aim of the Youth Department is the impartation of religious values to juveniles. It offers programs on Qur'an, religion, language classes, job application, sporting activities and advice 
regarding social problems that the youngsters might encounter. Despite the emphasis on the social aspect of the educational activities of the department, the main aim of the department is to increase religious consciousness. A poem published in Milli Gazete, which is known to belong to Milli Gorus and plays an important role in propagating Milli Gorus ideology, outlines the ideal youth:

They show respect for and their obligation to our religion, the fatherland, the flag, they are concerned about those who betray the fatherland, they are dutifully devoted to the leader of Milli Gorus, Erbakan, our young people are self-aware and respectful...When it comes to their home or honour, their own life means nothing, or young people are self-aware and respectful. They study their history, restore their confidence, endeavor to follow in their forefathers' footsteps, they are faithful to the Qur'an and the Sunna, these soldiers, our young people are selfaware and respectful (Milli Gazete, 9/10 April 2005, p.10 from the Report of the German Federal Ministry of the Interior 2005).

Milli Gorus regularly stresses the main aim of its activities as integration but the organization's own publication IGMG-Perspektive stated that the activities are organized in order to develop young Muslim's Islamic identity and strengthen their religious feelings (IGMG-Perspektive, March 2005, p.10).

According to the journalist Metin Gur, who has written extensively on Milli Gorus in Germany and has been living in Germany since 1968, the so called "boarding summer education camps" are jihad factories that train young Muslims to become devoted jihadists. His research on 1999 Summer Camps of Milli Gorus reveals that the students who attended these camps were distributed the book of Necmettin Erbakan, the 
ideological leader of the movement, called The Foundations and the Jihad and were indoctrinated on the essence of jihad (Interview with Metin Gur, 24 May, 2007).

\section{g) Finance}

According to German law of associations, associations are not allowed to perform commercial activities. Therefore, Milli Gorus denies involvement in any commercial activity but in practice it has organic links with a lot of mostly Turkey-based Islamist companies (Interview with Metin Gur, 24 May, 2007). Milli Gorus states on its webpage that it is financed solely by its members and aside from the organization of pilgrimages and a book shop it does not perform commercial activities. A retired Milli Gorus imam in Cologne says that Milli Gorus has organic links with some Turkey-based Islamist companies, the most well-known of which are Kombassan Holding, Umpas Holding, Jetpa, Yimpas, Gorus Holding, Slim Holding and Selcuklu Holding. These companies collect money from Milli Gorus members in Germany claiming that by investing money in these companies they are serving Islamic causes and meanwhile their money will double. Milli Gorus members who agree to put money in these companies are assured that the money that they will earn is in line with Islamic faith since there is no interest involved, which is forbidden by Islam. The imam states that all the imams in Milli Gorus mosques were told by the General Secretariat to help the representatives of these companies who use Milli Gorus mosques to collect money. Jet-pa is one of these companies and one of the most well-known due to the fraud it was involved in Germany at the end of 1990s. After collecting almost sixty million Deutsche Marks from Milli Gorus members, the company declared bankruptcy. Gorus Holding is another Islamist 
company and high ranking Milli Gorus officials such as ex- chairperson of Milli Gorus in Germany, Osman Yumakogullari, are said to be among the owners of the company.

\subsubsection{Views of IGMG in Germany}

\subsubsection{IGMG and German Society: A Relationship Dominated By Distrust and} Skepticism

IGMG's views concerning German society are important indicators of the movement's radical stance towards the host society. Antonio Gramsci's notion of hegemony provides a valuable theoretical framework for understanding how a critical view towards the social, political and economic environment followed by a construction of a rhetoric of victimization forms the first step towards developing a counterhegemonic and oppositional stance in which the norms, values, beliefs and eventually the institutional structure of the host society is envisioned to be replaced by those of the counter-hegemonic force (Gramsci 1971).

Gramsci's sociology attributes great importance to cultural struggles in revolutionary social change. When most Marxists of his generation believed that the Bolshevik's capture of the Russian state in 1917 was the appropriate model for socialist struggle elsewhere, Gramsci recognized that class struggle in Western industrial societies would take a different form: "a war of position" characterized by long-term political battles within "civil society" (Billings 1990). To theorize this struggle he developed a political sociology at the center of which was his concept of cultural hegemony. Gramsci argues that class domination is an intellectual and moral victory as much as it is an economic fact. Dominant classes exercise cultural hegemony by winning the support of dependent groups by connecting the perceived interests of these groups with their own. 
As a result, subaltern classes absorb the ideas and worldviews of intellectuals uncritically, make them "common sense" and accept them as their own. For a counter-hegemonic force to develop, the society needs a consciousness transformation which is a movement from common sense to critical understanding (Billings 1990, 9).

IGMG in Germany has developed as a counter-hegemonic force which challenges the norms and values of the German society. Building on the economic, social and political marginalization of the Muslim community, IGMG has created a sense of victimization among its members and brought them together around a sense of common destiny and shared interests. This sense of victimization of the Muslim immigrant community by the German society and its institutions legitimized the creation of an alternative social space outside the cognitive and institutional structure of the German society where the common sense of the dominant culture is challenged and a critical understanding is developed. This critical understanding is a manifestation of an already existent counter-hegemonic force and therefore an important indicator of the level of radicalism. To that end, the rest of this section will be devoted to displaying the victimization rhetoric and skeptical understanding of IGMG towards German society.

An article entitled "Tendency of Violence Among Youngsters and the Bankruptcy of Politics" by Ilhan Bilgu in the February 2008 issue of IGMG Perspektive which is the official publication of Milli Gorus Germany is one of many Milli Gorus writings that display the distrust and skepticism of Milli Gorus towards the German society and its institutions. According to the article, there is an increasing racism among German public which is fueled by the politicians who use Islam and Islamophobia for political mobilization. The author states that immigrant children are always accused of being 
violent by both the German public and authorities but it is in fact the German education system that is responsible for the increasing violence among immigrant youngsters. By discriminating against the immigrant youngsters because of their religion and ethnicity, he argues, the German education system turns them into violent individuals. Xenophobia exists not only at the education system, he states, but at all levels of German society including the German police who "covers up the racist attacks against the immigrants" (Ilhan Bilgu, IGMG Perspektive, February 2008, 9).

Bekir Altas's article in the November 2005 issue of the IGMG Perspektive agrees with Ilhan Bilgu and argues that despite the EU regulations against racism, Germany has been resisting to the implementation of anti-racist laws. He states that Muslims are constantly being abused by the German society and its institutions and they have nowhere else to turn other than their own religion (IGMG Perpektive, November 2005, 31). Another article entitled "Perception of Islam in Western Media, Society and Politics" in the December 2005 issue of the journal talks about an anti-Muslim alliance between the German media, society and politicians. The article accuses the German institutions of "trying and convicting an Islamic way of life" which according to the author proves the "Clash of Civilizations" argument right. Another article in the same issue of the journal by Mehmet Dogan is another important indication of the "victimization" rhetoric developed by IGMG. The title of the article is "Human Rights: Are They Really for all Human Beings?". The author starts his article by giving a reference to the UN's Universal Declaration of Human Rights and argues that the UN could not deliver its promise. He argues that the most basic human rights of Muslims are being invaded just for being Muslim and calls for universal resistance to the oppression 
of the "Global Gendarmes" by which he implies the Western powers (IGMG Perspektive December 2005, 23). The article entitled "Rosa Parks: She Sat for Us to Stand Up" in the same issue strengthens the sense of being a victim in the hands of the "oppressors" and emphasizes the urgent need to resist oppression by associating Rosa Parks with the Muslims of Germany and the oppressive "White Man" with the German society. The author argues that Rosa Parks, who is a black woman who resisted giving her seat to a white man on the bus on 1 December 1955 in Montgomery, Alabama started "the most important resistance movement of the century". He praises Rosa Parks for her courage and calls all the oppressed Muslims to do the same (IGMG Perpektive December 2005, 24).

In Gramsci's sociology, transformation of consciousness from the common sense to a critical understanding is considered as the first step in introducing a counterhegemonic force. IGMG has carried out the "transformation of consciousness" by depicting Muslims as victims of an oppressive German society. As a result of this transformation, the "common sense" that West and its products such as secularism, democracy and human rights are morally superior is challenged and replaced by a new discourse in which the values and norms of German society are considered and portrayed as inferior.

The article by Fatma Yilmazer in the April 2008 issue of the IGMG Perspektive exemplifies the main elements of this new discourse. Yilmazer starts the article with an explanation of how language shapes perceptions and thus reality. She gives this assumption as an explanation for the miscommunication between Turks and Germans. She argues that since Germans and Turks use different languages, their perception of the 
same reality is quite different and this differentiation cannot be overcome even when they start speaking the same language since they already have acquired certain tools for interpreting reality through speaking their mother languages. The argument of the inherent impossibility of communication between Germans and Turks is laid out throughout the article by giving examples from different German and Turkish traditions in which the German traditions are belittled while Turkish traditions are praised. The process of constant emphasizing the victimization of Muslims by the German society has transformed the IGMG members' understanding of Germans from a Lockean "Other" to a Hobbessian "Other", which is exemplified in Yilmazer's conviction about the impossibility of communication between Germans and Turks. While Germans were regarded as a peaceful rival, a "Lockean other", at the beginning of the immigration process, they became a security threat, a "Hobbessian other", in time.This transformation initiated the process of questioning and eventually challenging the structure of the host society. This critical understanding towards the value system of the German society constitutes the most important indication of Milli Gorus's role as an actor that challenges the core values of German society and formulates an opposition strategy, an alternative discourse and thus identity for its followers.

\subsubsection{IGMG and Democracy}

Due to the pressures from the German government, the leaders of the IGMG in Germany do not make open statements against democracy. In fact, the opposite is true. The organization explicitly professes support for the free and democratic order in Germany and considers it as a model for Islamic countries. It regularly condemns terrorist attacks by Islamic groups. The Bundesverfassungsschutz, Germany's domestic 
intelligence agency, views all these public statements to be a façade created to obscure the true goals of the organization. German courts have frequently confirmed this assessment.

In 2004, the German security agency found a number of books with "explicit antiSemitic and, in some cases inflammatory content" in an IGMG mosque in Munich (Annual Report on the Protection of the Constitution, 2005). This kind of provocative material can be found regularly in the Milli Gazete (National Newspaper), which is a Turkish daily newspaper that plays a key role in maintaining cohesion within the Milli Gorus movement and propagating its ideology. Milli Gazete is published in Turkey but a European edition is also sold in Germany. Despite the public statements made by the IGMG leadership that IGMG cannot be equated with Milli Gazete, security services view it as unequivocally belonging to the Milli Gorus movement and as well as serving as its mouthpiece. The newspaper can not only be found in IGMG mosques and events but also in the IGMG headquarters in Cologne.

According to the 2005 report of the German security services, Milli Gazete attempts to recruit supporters from within the IGMG. Representatives from the newspaper have taken part in IGMG events and subscriptions for Milli Gazete are given away as prizes at IGMG events. The following statement made by an IGMG functionary in Germany shows how strongly IGMG identifies with the newspaper:

"Milli Gazete is our lifeline. It should be our primary task to stand up for it, to read it and to motivate others to read it" (Annual Report on the Protection of the Constitution, 2005).

The survey results, articles from the Milli Gazete and IGMG Perspektive and the interviews that were conducted among the IGMG members reveal the anti-democratic 
stance of the IGMG in Germany. 49 percent of the IGMG members disagreed or strongly disagreed with the statement that democracies may have problems but it is better than any other form of government. 45 percent of them said that having a democratic political system was fairly or a very bad way of governing, 75 percent mentioned that democracies were not good at maintaining order.

IGMG in Germany believes that Islam provides a framework for both the individual and the political and social life. Only a life that is guided by Islam can achieve the "just order".

As regards sharia law, there are two types of politics: Despotic politics, that is politics which goes directly against the rights of the people and which prohibits sharia; and just politics, that is politics which saves the rights of the people from the hands of the despots, which banishes subjugation and evil, and thwarts those who sow the seeds of discord and unrest; it is part of sharia law...Politics can create a just foundation based on sharia law...If politics declares itself independent of sharia, it makes itself absolute and itself becomes the source of subjugation (Milli Gazete, 5 July, 2005, p.13 from the Annual Report on the Protection of the Constitution 2005).

An article by Unal Koyuncu in the March 2005 issue of the IGMG Perspektive agrees with the above statement about the centrality and inseparability of sharia from the life of a Muslim. The author severely criticizes Bassam Tibi's Euro-Islam argument that Islam can be compatible with Western ideals of democracy and secularism only if it is confined to the individual sphere as a code of ethics and completely excluded from the government structure. He blames Bassam Tibi for being ignorant about his own religion 
and praises Heinz Halm, who is a leading German Islamist and a professor of Islamic studies at University of Tubingen, Germany. Koyuncu agrees with Halm's understanding of sharia as an organic part of Islamic faith and mentions the impossibility of separating sharia from a life that is guided by Islam (IGMG Perpektive, March 2005, 21).

As mentioned earlier, despite the lack of open anti-democratic statements from the IGMG leaders due to increasing pressure from the German government, their views in regards to democracy can be understood looking at the stance they have taken in the public debate on Euro-Islam. Despite the ongoing debates about the roots of the notion of Euro-Islam, the concept was introduced to European public debates by Bassam Tibi, a Syrian political scientist who has become a German citizen and has been living in Germany since 1962. The term refers to Islam in Europe, often assuming a liberal and progressive interpretation. Tibi sees Euro-Islam as acceptance of separation of church and state and democracy as an ideal system of government (Tibi 2006). He formulates "five pillars of Euro-Islam" making a reference to the Five Pillars of Islam which are the five duties incumbent on every Muslim. The "five pillars of Euro-Islam" are "opposing the traditional understanding of sharia, adopting secularism, adjusting Islamic way of life to the norms of the industrial society, being faithful to the constitution of the host country and adopting pluralist democracy" (IGMG Perpektive, March 2005, 27.) He supports the necessity of confining Islam within the individual sphere as a code of ethics and excluding it from the political system as a system of government. While his argument has been adopted by secularist Turkish elite in Germany such as Dr. Faruk Sen, it faced severe criticisms from the IGMG in Germany. IGMG devoted its March 2005 issue of the IGMG Perspektive to the debate on Euro-Islam. Its stance on Euro-Islam is an important 
indicator of its stance on the role Islam should play in public and political life of Germany.

The article by Ilhan Bilgu summarizes the general argument of the IGMG on the issue of Euro-Islam. The author condemns Dr. Faruk Sen and Bassam Tibi for advocating an Islam that is detached from the public and political life. He criticizes the statement by Faruk Sen that he is not against Islam but against sharia and argues that Islam cannot be an individual matter since it regulates all spheres of life including political life (IGMG Perspektive, March 2005, 24). They support the stance of Tariq Ramadan on the issue. Tariq Ramadan is the son of Said Ramadan and the grandson of Hassan al Banna, founder of the Muslim Brotherhood in Egypt. His father was a prominent figure in the Muslim Brotherhood and was exiled from Egypt to Switzerland where Tariq Ramadan was born (Olivier Guitta, 2006). In 2004 his visa was revoked by the US State Department and he was forced to resign his position at the Joan B. Kroc Institute for International Peace Studies (Washington Post, December 15, 2004). Ramadan's approach to the issue of Euro-Islam differs from that of Bassam Tibi and Faruk Sen. He argues that Islam and Muslims can exist within the European public space only by reexamining the fundamental texts of Islam (primarily the Qur'an) and interpret them in light of their own cultural background, influenced by European society while neither Tibi nor Sen makes a reference to the need to go back to the fundamental texts of Islam and simply accept the moral superiority of Western institutions such as democracy and secularism (IGMG Perspektive, April 2005, 31).

The IGMG reactions given to the suggestions by Euro-Islamists that Islam should be kept as a code of ethics and not considered as a political project reveal IGMG's 
skeptical stance towards a Western style democracy and its call for a broader place for Islam in public life of Germany.

\subsubsection{IGMG and Secularism}

The position that IGMG took on the Euro-Islam debate provides the opportunity to analyze IGMG's ideological standpoint on Western notions of democracy and secularism. By rejecting Euro-Islam's Islam definition as a code of ethics that regulates only the individual sphere of human existence, IGMG envisions a world where Islam plays the dominant role at all levels of human activity including politics. This understanding of Islam reflects the traditional view of the fusion between religion and state in Muslim society where God and State are one and the same and rejects the French notion of secularism that separates these two entities making the former subject to the latter's authority. The article by Ahmet Bakcan in the December 2005 issue of IGMG Perspektive provides important insight into IGMG's views on French model of secularism.

Ahmet Bakcan evaluates the 2005 uprising of Muslim immigrants in France which started as a result of the death of two youths of Tunisian and Mauritanian descent on October 27, 2005, who were electrocuted in a power substation while fleeing the police. The explosion quickly spread to hundreds of cities and towns and by the end of the first two weeks of the uprising more than 7,000 vehicles and dozens of buildings had been destroyed, more than 2,500 people arrested, thousands of police were mobilized and a state of emergency was declared (Zeleza 2005). Bakcan considers the uprising as "a sign of the bankruptcy of French secularism" (IGMG Perspektive, December 2005, 7). He argues that the Muslim immigrant youth in France is finally showing its anger 
towards a system which has denied them their basic rights of living their religion and discriminated against them. The author underlines the different immigrant policies undertaken by European states and considers the French model as the most unsuccessful one. He argues that "The French model prefers individuals to be monotypes and live their ethnic, religious and social differences in their individual spheres, and severely rejects application of these differences to public and political sphere. As a result of this understanding, The French government introduced the law on March 15, 2004 that bans Muslim women's hijab" (IGMG Perspektive, December 2005, 7). The author condemns French model of strict separation of church and state for causing alienation of the Muslim immigrants and their radicalization.

Another article by Hatice Sahin in the same issue makes a similar argument and blames French model of secularism for the suffering of thousands of Muslim girls who have been "forced out of the school system because of their religion". She provides examples of Muslim girls who stopped going to school due to the ban on wearing religious symbols to the school that was introduced by the French government in 2004 (IGMG Perspektive, December 2005, 10).

Oguz Ucuncu, the Secretary General of IGMG, argues that the main aim of the French model is to "reduce the Islamic life to prayers and the mosque to a mere place of worship" (IGMG Perspektive, March 2005, 32). His statement makes it clear that he envisions a community where mosques are more than places of worship and they serve as the core of all segments of social and political life as they were during the first Islamic state that was established by Prophet Muhammad in Medina. Mescid-i Nebevi was built by Prophet Muhammad as a mosque in Medina around 622 A.D. but became the main 
government building where the decisions for war and peace were taken, political matters were discussed and administrative duties were carried out (Nesei, Mesacid, 20). Mescid-i Nebevi is the symbol of the unity of state and religion, an Islamic ideal that was interrupted by the forces of modernity. Ucuncu's criticism of French secularism which removes the political role of the mosque and reduces it to a mere place of worship reflects the aspiration for that Islamic ideal.

Dursun, a member of IGMG who came to Germany as a guest worker and has been living in Aachen since then, evaluates the uprisings in France as follows:

The cars that are burning on the streets of Paris are the scream of the oppressed Muslims. They have been too patient in all these years in the face of unbearable injustice, inequality and oppression by the French state. Is it not clear that the idea of separating religion and state not working? When are those who have been worshipping the French model in Turkey going to realize that God did not mean it to be this way? (Interview with Dursun, 20 May, 2007).

Behind IGMG's reactions given to the uprising in France lies a firm conviction that secularism is an alien idea to Islam and thus cannot respond to the needs of Muslims. By criticizing the French model of secularism, IGMG members not only condemn the French state but also the Turkish state which adopted a French model of secularism in 1923 as a result of Ataturk's modernization and Westernization project. The survey results confirm that these anti-secular tendencies among the leadership are shared by IGMG members as well. 75 percent of those who were interviewed agreed or strongly agreed with the statement that politicians who do not believe in God are unfit for public 
office. 49 percent of them disagreed or strongly disagreed with the statement that religious leaders should NOT influence how people vote in elections.

\subsubsection{Islamism in the German Context}

\subsubsection{Islam as a Master Signifier}

The relationship between Islam and Islamism is not a direct relationship as suggested by orientalists who view Islamism as a natural continuation of Islamic faith. It is neither merely opportunistic as argued by anti-orientalists who maintain that Islam is largely irrelevant for understanding Islamism since it is just a tool to achieve materialistic gains. Rather, the relationship between Islam and Islamism is constitutive. Both Islam and the identity of Islamism are transformed in the process of articulation of Islam to the Islamist project. Islamism is able to articulate Islam as a central political category by building on the traditional indivisibility of politics and religion in Islam and transforming Islam into a master signifier (Sayyid 2003, 46).

Islamism is an attempt to make Islam the master signifier to which all other discourses must refer. What makes Islam a candidate for a master signifier? Islamists unify the ways Islam operates in different discursive configurations by defining Islam as din (faith), as dunya (worldly life and concerns) and as dawla (a political order). The Islamist project traces the existence of Islam in different discourses and combines them in a hegemonic discourse to which all other discourses refer (Sayyid 2003, 47). The result is an understanding of Islam that monopolizes all spheres of Muslim's life as a faith, as a complete way of life and as a political order. It is a hegemonic discourse that involves a totalizing reduction of the field of the infinite play of meaning. It shapes the way the Muslim gives meaning to the world and it has supremacy over all other discourses. 
Formulating a hegemonic discourse involves the negation of identity in the double sense of the negation of alternate meanings and the negation of those who identify themselves with these alternate meanings. The negation of identity gives rise to social antagonism. According to Laclau and Mouffe (1985), a discourse sets up its limits by means of excluding a radical otherness that has no common ground with the differential system from which it is excluded and that therefore poses a constant threat to that system (Boucher 2000). Laclau calls this a "constitutive outside" (1985).

Islamism could be able to establish itself as a counter-hegemonic discourse as a result of its ability to present itself as the "radical other" of the German society and the values that it represents. Through the negation of the meanings and identities that German society generates, Islamism reproduces the West and Western ideals as the "constitutive outside" of Islam. The victimization rhetoric and the consequent challenging of the superiority of Western products such as secularism and democracy by IGMG is part of an attempt to introduce Islam as the master signifier in the lives of Turkish immigrant community in Germany.

\subsubsection{Islamism as an Opposition Strategy}

Islamism in Germany is a resistance to marginalization. The Turkish immigrant community lives in a state of economic, political and social marginalization which is conceived as a threat to their existence both as individuals and as a community. They choose Islamism as their means of resisting this marginalization because Islamism is offered as a discursive element of rupture, a structural antithesis to Western thought which is believed to be responsible for the disadvantaged position of the Muslim immigrant community in Germany. 
Islamism conceptualizes marginalization of Muslims as the product of a historical conspiracy by the Western world against Islam. It argues that Muslims are excluded from the political, economic and social structure of Germany due to the historical Western perception of Islam as an enemy. This perception "has been shaped by the Crusades, taken the form of revenge with the Reconquista (expansion of Christian kingdoms over the Iberian Peninsula at the expense of the Muslim states of Al-Andalus) and become institutionalized with the orientalist definition of the Islamic world" (IGMG Perspective, December 2005, 20). Islamism capitalizes on the perceived and real discrimination against the Turks by German society. It portrays the Muslim community as the victim of German "oppression" which is only a small part of a bigger Western plan to enslave the Muslims of the world. By associating the Muslims with the "oppressed" Black community of the US and Germany with the oppressive "White Man", Islamism generates a counter-hegemonic discourse that challenges the legitimacy of the Western culture and the injustice that it produces. In the IGMG Perspektive, several references have been made to the notion of "just order", the main tenet of the movement, and it was argued that the salvation, liberation and justice would come only through Islam (Annual Report on the Protection of the Constitution 2005).

IGMG have produced a counter-hegemonic movement in which Islam became the master signifier and German/Western society formed the "constitutive outside". The movement is comprised of those who are or perceive themselves and their interests as excluded, disadvantaged and repressed by the social, political and economic structure. By imposing the idea that there is a "crisis" that threatens the very existence of the Muslim community which must ultimately be explained by the "Western conspiracy", IGMG 
legitimizes the creation of an alternative social space where the norms, rules and values of the dominant society are replaced by those of Islam. Hulusi Unye finishes his article in the IGMG Perspektive's February 2008 issue with these remarks:

As we are just starting a new year, we pray Allah to help the Muslim world which has been fighting against repression, oppression, torture and injustice, where blood and tears have been pouring reach the happy endings that Prophet Muhammad and his companions reached with the Hijra (IGMG Perspektive, February 2008, 17).

Hijra is the migration of Prophet Muhammad and his followers to the city of Medina where he established the first Islamic state in $622 \mathrm{CE}$. The author portrays the Muslim world as the victim of oppression and injustice and implies that only Islam as a social, political, religious and economic project can liberate the oppressed peoples of the Muslim world. His consideration of the establishment of an Islamic state as the result of Hijra as the only way of liberation for Muslim peoples illustrates the break of the Islamist project with traditional Islam which considers Islam more as a code of ethics than a political project.

Islamism is a response to social marginalization. It is not a medieval program whose main framework can be found in the holy texts but one that responds to the strains of the twenty first century. Islamism is a constructed religious identity which finds its breeding ground in the modern Western context. It represents a new phenomenon because with its political agenda it not only challenges the secular character of traditional Islam but it also rejects the passive and apolitical nature of fundamentalism that only deals with the interpretation of Holy Scripture. Islamism offers a modern religious 
identity that is capable of coping with the challenges of the modern life. IGMG could be able to conceptualize marginalization of Turkish immigrant community as the result of a "Western conspiracy" that is "imperialistic", "oppressive", and "unjust" and argue that only a life that is guided by Islam in all spheres can bring equality, justice and thus happiness. It developed a counter-hegemonic discourse in which it is not the marginalized social processes that ascribe the significance of social identity and which challenges the norms and values of the host society. It has offered Islamism as the only solution that can replace the existential anxiety of the immigrant community with positive ontological condition.

I am covering my hair to protect myself, to draw my boundaries. This is my armor, the only weapon that I have to survive in a country which attacks me, my beliefs, and my values on a daily basis. I am different, so they (Germans) said as I was growing up and now I accept: Yes I am different; I am a Turk, a Muslim. They (Germans) lost us long time ago and now they want us to disappear, to be invisible. But we won't. We will always be there right in front of their eyes with our covered heads (Interview with Ayse in the old IGMG Headquarters, May 25, 2007).

The immigration experience resulted in a process of "rethinking of West" among the Turkish immigrant community. The social, economic and political exclusion experienced in Germany transformed the Turkish immigrants' perception of West from a West as an opportunity for a better, more humane life to a West as a threat to their very existence. West was transformed from a "Lockean Other" where the self perceives the Other as a peaceful rival to a "Hobbesian Other" where self perceives the Other as a 
security threat (Kosebalaban 2003). Islamism is an opposition strategy of an immigrant community in the face of exclusion and discrimination by a "Hobbesian Other". It is the return of the "oppressed".

\subsection{IGMG IN THE NETHERLANDS}

\subsubsection{Historical Development of IGMG in the Netherlands}

IGMG has two regional associations in the Netherlands: North Holland and South Holland Milli Gorus. North Holland Milli Gorus Association defines itself as "an Islamic community that serves the cultural, religious and social needs of the Muslim community in the Netherlands" (official website). It not only organizes activities to teach Islam to new generations and introduce it to the Dutch society but also "carries out activities in the social, cultural and political life of the Netherlands and represents its members in every one of these platforms" (official website).

The organization introduces itself by the below statement that it has made on its official website:

The majority of the Milli Gorus members do not see themselves as guests but rather a permanent part of the Dutch society. Our organization is aware of its responsibilities and therefore considers the protection of the welfare of the society in which we are living as its main duty. As part of the Umma, our organization also has responsibilities toward the Muslims of the world and humanity in general. Aware of these responsibilities we work to enhance goodness, fellowship and friendship in society, look for solutions to the economic, social and political problems. In an attempt to find solutions to common problems, we look at Islam and universal values. We believe that in order to fight against inequality and 
injustice, in order to universalize goodness and base all relations on the notion of justice, institutionalization as a community is essential. As North Holland Milli Gorus Association, we are working hard to create a community that is helpful for everybody (Official website).

Milli Gorus started its activities in the Netherlands in a building in Colsestraat, Rotterdam. The association in Rotterdam was named Rotterdam Iskenderpasa Mosque. In 1981 it took the name Muslim Communities Association and in 1986, it became the Islamic Federation of Holland. While the headquarters were initially in Rotterdam, The Hague and Schiedam became the headquarters in 1997. On 24 May 1997, the movement was separated into two regions: North Holland Milli Gorus and South Holland Milli Gorus. Today the Islamic Federation of Holland represents only the South Holland Milli Gorus (official website).

\subsubsection{Structure of IGMG in the Netherlands}

IGMG has two regional associations in the Netherlands: North Holland Milli Gorus Association and Islamic Federation of Holland which represents IGMG members in the southern part of the Netherlands. These two associations do not differ in their worldview. IGMG was separated into two regional associations in the Netherlands to make the administration more effective (Interview with Mehmet Yaramis, May 29, 2005).

\subsubsection{North Holland Milli Gorus Association}

North Holland Milli Gorus Association has 23 mosques, and 75 associations that include women's and youth department. It has 603 administrators, 4394 registered members and 7500 sympathizers. Depending on their respective tasks, the cultural, 
religious and social services of the IGMG are offered either by the central administration or local communities. Local mosques which provide the necessary infrastructure such as praying rooms and imams constitute the smallest unit of IGMG's religious community. Mosques work with women's and youth department in responding to the needs of the local community. It is the responsibility of the central administration to organize communication between local communities. It also develops cultural and educational programs and coordinates the attempts to establish religious services by the local communities. It undertakes the organization of hajj (pilgrimage to Mecca) and the solidarity fund of the burial services (official website).

The association states that its main aim is to increase the socio-cultural level of all the Muslims in the Netherlands and help their integration and participation in the democratic structure of the Netherlands. It asserts that the Milli Gorus association supports the multi-cultural, multi-religious structure of the Dutch society which it believes forms the basis of a peaceful and free community (Official website).

\subsection{Women's Federation}

One of the most active departments within the North Holland Milli Gorus Association is Women's Federation. The department organized its activities under the name of Muslim Women's Platform of Holland until June 1999. Starting from this date, it was integrated into the North Holland Milli Gorus Association and has been part of it since then. The federation has a separate bylaw which establishes the main duty of the federation as "providing the integration of the Muslim women into the Dutch society" (official website). The federation maintains 23 different women's department which are comprised of 200 volunteers who "work to fulfill the main aim of the federation" (official 
website). By its own account, the federation has 1445 registered members, 7000 sympathizers and around 17,000 people participate in their activities.

The administrative activities of the federation are carried out by the board of directors which is comprised of a regional chairperson, secretary, head of the social services, head of education, head of media relations, head of children's club, head of youth department, accountant, and head of external relations. The federation has several projects which aim to educate women on a wide range of issues including marriage, sexual life and domestic violence. The Domestic Violence Project is one of the most recent projects of the federation. It has organized public seminars in which scholars were invited to talk about the psychological profiles of those who have tendency towards violence and way of coping with domestic violence. Another project entitled "Crossroads Project" aims to educate women and young girls on issues related to marriage including sexual life (official website).

\subsubsection{Islamic Federation of Holland}

It was established in 1981 and has almost 4000 registered members today. The federation summarizes its duties under five headings: representation, coordination, supporting local communities, public relations and protection of the rights and interests of its members. It states that its main duty is to "help Muslims be successful in the social life of the Dutch society" (official website). The federation has 60 youth, women's and student's organizations. It coordinates the activities of 18 branches that operate under the federation. The branches consist of mosques, women's and youth organizations and dormitories for students. The branches carry out activities such as Dutch language classes, tutoring for students, sports activities, seminars and panels, picnics as well as 
religious instruction. They work with local Dutch authorities on joint initiatives on healthcare, housing, services for elderly and education. Like all other Milli Gorus Associations, the Islamic Federation of Holland undertakes the organization of hajj (pilgrimage to Mecca) and helps Muslims communities in Bosnia and Gazze. The administrative activities are carried by a board of directors which is comprised of the chairperson, secretary, accountant and the representatives of irshad (religious guidance) department, department of organizational development, department of education, department of social services, department of media relations, department of inspection, department of administration, women's department and department of youth (official website).

\subsubsection{Views of IGMG in the Netherlands}

\subsubsection{IGMG and the Dutch Society: A State of Peaceful Coexistence}

Todorov (1984) argues that identity is constructed through the distinction from the otherness. The concept that the self requires the Other to define itself has been expressed by many scholars and philosophers. Hegel (1977) was among the first to introduce the idea of the other as constituent in self-consciousness. Sartre (1943), Jacques Lacan (1977) and many others all shared the same argument.

Lawrence Cahoone (1996) explains the importance of the construction of the Other as follows:

What appear to be cultural units- human beings, words, meanings, ideas, philosophical systems, social organizations- are maintained in their apparent unity only through an active process of exclusion, opposition, and hierarchization. Other phenomena or units must be represented as foreign or "other" through 
representing a hierarchical dualism in which the unit is "privileged" or favored, and the other is devalued in the same way (Cahoone 1996).

Although the self has to construct an Other for its own realization, the way in which the representation of the Other is construed follows different paths. The self can construct an entirely conflictual Other or a peaceful rival depending on the context in which the construction occurs. The IGMG developed its Islamist identity in a context which is known for its tolerant approach towards societal differences. Contrary to Germany where the institutional structure and the attitudes prevailing in the country with respect to the immigrants can be characterized as assimilationist, the Netherlands is known for its multi-culturalism. The prevalence of the institutional arrangement of "pillarization", relatively easy naturalization process, voting rights in local elections and right to dual citizenship have provided the immigrants in the Netherlands an environment where they can be integrated into the host society yet preserve their religious identity. Therefore, the Dutch society has been defined not as a security threat but as a peaceful rival by IGMG. Despite the lack of common identification with the West, IGMG has displayed a desire to integrate with Western institutions.

Canan Uyar is the chairperson of the North Holland Milli Gorus Association's Women's Federation. I interviewed her on June $6^{\text {th }}, 2007$ in her office in Amsterdam. She came to the Netherlands when she was fourteen and she has been part of IGMG since 1993. She says that she grew up in the Netherlands, a country where everybody on the street smiled and said hi to each other, nobody was discriminated because of her/his religion or color. 
We used to go to Germany to visit relatives who lived there. I could not wait to come back to Holland. When we passed the border to come back to Holland I used to say "Thank God, I am home". Things are not the same after the September $11^{\text {th }}$ but this is still my home. I still have the Holland where everybody lived together peacefully in my mind (Interview with Canan Uyar, June $6^{\text {th }}, 2007$ ). I met Ismail in North Holland Milli Gorus Association's Women Federation's meeting in Noordwijkerhout, a small town in the western Netherlands, on June $16^{\text {th }}$, 2007. He did not want his full name to be revealed. He made similar positive comments in regards to the Dutch society. He explained his positive remarks with an analogy:

If you beat your child every day, he does not turn out to be a loving, caring man. He probably becomes a trouble maker. But if you love him, care about him, help him when he needs you, he will love you back.

When I asked him if they were "loved" by the Dutch society, he replied:

I don't know if I can go that far but at least we were not hated. Yes we are different but look at the room, everybody is different from each other, what is important is the intention to find a common ground to build on...We are part of this society, we vote, take part in the decision-making process, have our voice heard. We cannot be ungrateful. This country gave us the opportunity to be part of it, to be a Muslim, a Turkish and a Dutch.

According to the survey results, 49 percent of the respondents said that they would identify themselves firstly with the Islamic world while 28 percent identified themselves with the Netherlands, 11 percent with Turkey, 7 percent with their town/locality, and 1 percent with Europe. 75 percent stated that they thought their rights 
and interests were protected by the Dutch government partially and 62 percent said that they felt that they were part of the Dutch society partially. The majority of the respondents' identification with the Islamic world and yet their trust in the Dutch institutions indicate that IGMG members have established an identity in which Western ideals are not in conflict with an Islamic life style. The Dutch society is not perceived as a threat to their existence as in the German case but as an opportunity for peaceful coexistence. Instead of a Hobbessian state of anarchy in which every actor is under constant threat from other actors of the system, to the IGMG members the Dutch society exemplifies the qualities of a Lockean state in which different parts of the system coexist peacefully. Contrary to the IGMG in Germany, its Dutch counterpart perceives the society in which it lives as a "Lockean Other", a peaceful rival (Kosebalaban 2003). The Islamist identity in the Netherlands harbors both traditional and modern elements in it. It does not exist despite the West or because of the West but with the West.

\subsubsection{IGMG and Democracy}

IGMG's relationship to democracy is determined by its relationship to the West thus to the Dutch society. IGMG does not perceive Dutch society as posing a threat to its existence; rather it perceives it as an actor whom it shares the Dutch public space on equal terms. It regards itself as one of many different identities that exist within the Dutch society without attributing a hegemonic status to any of them. This understanding of Dutch society as just another actor that operates within the Dutch public space avoids the establishment of the West as a confrontational Other, paving the way for a peaceful coexistence of the West and Islam in the minds of IGMG members. It is their experience as Muslims in a Western context that shapes their perceptions in regards to the 
relationship between Islam and democracy. They do not consider Western notions of democracy and Islam as mutually exclusive; rather the relationship between them is defined as a dialectical relationship where each discourse shapes and is shaped by the other. The victim/oppressor relationship of the German case does not exist in the Dutch case. IGMG members see themselves not as the subject in their relationship to Western institutions as in the German case but as objects which have the power to initiate changes.

The feeling of powerlessness that is dominant among the IGMG members in Germany does not exist among the IGMG members in the Netherlands. Instead, the Dutch IGMG members believe in their power to have an impact on the Dutch society and institutions which is reflected in their trust to Dutch institutions in the surveys. It is this belief in their ability to participate in the decision-making process as equals that leads to a trust towards the democratic process. A Milli Gorus imam in Utrecht, like many other Milli Gorus members that I talked to, expresses his disagreement with the alleged incompatibility of Islam and democracy.

Islam and democracy are seen as fire and ice that can never live together by many. But this assertion does not reflect the reality; rather it reflects an ideology. I have been living in this country for sixteen years. I have been exercising my democratic right to vote, to take part in the decision-making process and yet I pray five times a day, I perform my religious duties as a Muslim as well. They are two separate things. Islam can live in a democracy, you just have to look at our history in this country to believe that (June $23^{\text {rd }}, 2007$, Utrecht). 
The legitimacy attributed to democracy as a system of government in fact is the legitimacy attributed to the Dutch society. The experience of peaceful coexistence within the Dutch society has led to the conviction among Milli Gorus members that democracy is capable of providing justice and equality. Mustafa is a student at the Islamic University of Rotterdam's Institute of Islam. He was born in Utrecht but he visits Turkey every summer with his family. He states that he values democracy more when he goes to Turkey.

I have cousins who had to stop their college education because of the ban on headscarf in Turkey. The state tells them that if they want to go to college, they have to take off their headscarves. We call Turkey a democracy but unfortunately it is a democracy that could not come to terms with its Muslim background. While I cannot live my religion in a country, the 99 percent of whose population is Muslim (referring to Turkey), I can attend an Islamic college in a Christian country. How can you explain that? Certainly with the lack of true democracy in Turkey (Interview with Mustafa, 24 June 2006, Utrecht).

The survey results confirm the above statement. 80 percent of the Milli Gorus members interviewed agreed or strongly agreed with the statement that democracies might have problems but they are the best system of government. While 75 percent of the Milli Gorus members in Germany stated that democracies were bad at maintaining order, only 57 percent of Milli Gorus members in the Netherlands made the same statement.

Democracy is seen as an opportunity to live an Islamic life, not a threat to it. While Islam still constitutes the most important aspect of their identity, they do not consider it to be an obstacle to embrace Western norms of democracy. They consider it 
the only viable way to have their voices heard. They utilize the opportunities that democracy provides to them. They vote, establish their own Islamic organizations, even their own schools, receive public funding for their activities, and thus redefine the relationship between Islam and West, transforming it from a constant site of conflict to a state of peaceful coexistence.

\subsubsection{IGMG and Secularism}

In the introductory chapter, Islamism is defined as an ideology that turns traditional Islam into a sustained and systematic program that includes political, military and economic affairs. It is argued that Islamism is a term that covers 1) a variety of institutional forms (they can be local, transnational, or international) 2) very different political forms, ranging from underground organizations whose activities are banned by the host state to the organizations/movements that are considered essential for the adjustment of Turkish immigrants in the host countries 3) very different methods of action, ranging from encouraging conversion from within the mosques to more radical social and political mobilization including violent action (Pedersen 1999). Despite its moderate stance, the Dutch IGMG is still an Islamist movement just like its German counterpart. The definition of Islamism as an Islamic political, economic and social project automatically reveals the stance of IGMG on the issue of secularism. Unlike the apolitical nature of traditional Islam, Islamism ascribes Islam an important role in the political realm. The nature of this role, however, varies and it is this role that determines the nature of the Islamist movement. Both IGMG in Germany and IGMG in the Netherlands support the existence of Islam in political sphere, which is in line with their Islamic ideology. IGMG in Germany, however, advocates Islam as an institution that 
constitutes an alternative to the democratic system, while IGMG in the Netherlands advocates Islam as a code of ethics that should guide the political world.

Bilal is a 48 year old Milli Gorus member. He has been living in Rotterdam for fifteen years. He owns a small internet café in Rotterdam. He says that he has read extensively on Islamic faith and history of Islam. He states that his Islamic faith is a choice that he made consciously. It took several years of "soul searching" for him to get to this point. His statement clarifies the distinction:

Islam is a way of life. It regulates every segment of human existence: from politics, to economy, from marriage to parenthood. One can find all the answers he/she might have in Islam. When we say this in public, people get scared. They think that we want to destroy their democracy, their system of government because they don't understand Islam; they don't understand what we mean when we make this statement. An Islamic state is not our aim; it is just one of the means to live your life in line with your Islamic faith. So the aim is to be able to perform your religious duties freely, to live in a society that is based on justice, equality and freedom. If you can achieve these in a democracy, then there is no reason for an Islamic state. If I can go to my mosque and pray five times a day, if my wife can cover her head freely, if I can read my Qur'an whenever I want, why would I want an Islamic state? I can do all these things in the Netherlands, in a democratic state. Why would I want to change that democracy which has provided me everything to practice my religion freely with a different form of government? Allah says in Qur'an that there are five pillars of Islam: Shahadah (profession of faith), Salah (ritual prayer), Zakah (alms tax), Sawm (fasting during Ramadan), and Hajj (pilgrimage to Mecca). Establishing an Islamic state is not one of them. Of course this doesn't mean that pray five times a day, perform your religious duties and don't worry about politics or economy. We are social, economic and political beings and it is our responsibility to establish a just society. How can we do that? By internalizing the notion of justice and applying it to economics, society and politics. It is at this point when Islam comes in. It provides us a definition for justice. Islam asks the rulers to rule justly, not oppress their people. So Islam regulates politics as a guide. Politicians, rulers whether they are in a democracy or a theocracy, should follow these norms if they want to be good rulers. So, as a short answer to your question: Yes, Islam is in politics, in economy, in society, everywhere where there are human beings (Interview with Bilal, June 26, 2006, Rotterdam). 
Islam is kept in the political sphere not as a system of government but as a normative framework by IGMG, which explains the lack of differentiation in the level of anti-secularism between the German IGMG and the Dutch IGMG. Despite the high level of support for democracy among the members of IGMG in the Netherlands while its Dutch counterpart displays serious skepticism toward democracy, both IGMGs maintain similar levels of anti-secularism. 39 percent of those Milli Gorus members who were interviewed asserted that religion should not affect government decisions while the percentage for the Netherlands is 48 . The questions in the anti-secularism section were designed to reveal their stance on the issue of separation of religion from the political realm. Both groups answered positively to the questions of whether Islam should have an impact on the government. The questions, however, did not differentiate between the types of impact Islam might play in the political decision-making process.

\subsubsection{Islamism in the Dutch Context}

\subsubsection{Islam as a Religio-Cultural Signifier}

Contrary to the German IGMG's understanding of Islam as a master signifier, the IGMG in the Netherlands perceives Islam as a religio-cultural signifier. Master signifiers are defined as those signifiers that the subject most deeply identifies with and which have a key role in the way he/she gives meaning to the world. The master signifiers reorient the subject vis-à-vis all of the other signifiers which structure his/her sense of herself and the world (Lacan 2001). IGMG in Germany makes Islam the master signifier by defining Islam as din (faith), as dunya (worldly affairs and concerns) and as dawla (a political order). The Dutch IGMG, on the other hand, defines it as din (faith) and as dunya (complete way of life) and transforms the existence of Islam in the political sphere from 
being the form of the political order to being the moral authority over that political order. While Islam has monopoly in all three aspects of life as a faith, as a way of life and as a political order in German IGMG's rhetoric, it loses its monopoly in the political sphere and becomes a religio-cultural signifier in Dutch IGMG's rhetoric. Islam is not a master signifier that structures the individual's sense of herself/himself and the world vis-à-vis all of the other signifiers anymore but it is a signifier less than that.

Clifford Geertz's understanding of religion as a cultural system provides a valuable theoretical tool in understanding this transformation that takes place in IGMG's definition of Islam. Geertz perceives religion as a system consisting of symbols that convey meaning. According to Geertz, a religion is

1) a system of symbols which acts to 2) establish powerful, pervasive and longlasting moods and motivations in men 3) by formulating concepts of a general order of being and 4) clothing these concepts with such an aura of factuality that 5) the moods and motivations seem uniquely realistic (Geertz 1973, p.90).

What is important for the purpose of this study is to understand the dual aspect of religious content. According to Geertz, religiocultural symbols are both shaped by reality and at the same time shape reality to themselves. The third part of Geertz's interpretation rests on the assumption that religion as a cultural system contains concepts of a general order of existence. These concepts are essential to the believers and the existence of these concepts of order forms the life force of religious symbols.

In this respect, man depends upon symbols and symbol systems with a dependence so great as to be decisive for his creatural viability. This disquieting 
sense that one's moral insight is unequal to one's moral experience is present in all religions and can bring about a crisis (Tibi 1990, 12).

What is important in Geertz's formulation of religion as a cultural system is his focus on the dynamic nature of the relationship between the religious man and the religious symbols. They are in a dialectical relationship in which both shape and are shaped by the other. Religions, as cultural systems, offer a way to perceive reality and they, or their conceptions, change as that reality changes (Tibi 1990, 9).

IGMG in the Netherlands have formulated an understanding of Islam as a response to changing realities in order to avoid the "crisis" that otherwise would occur in the meaning world of the Muslim immigrant community. In Islamic faith, Islam embraces all spheres of life and has strict commandments for conduct within them. Islamic law, the sharia, is the expression of these sacral instructions. It is the complex of theological and worldly regulations of Islam and constitutes an alternative to democratic institutions (Tibi 1990, 58). IGMG in the Netherlands have transformed the understanding of sharia in order to avoid a possible clash between two systems of meaning. IGMG perceives its existence in the Dutch society as a peaceful existence that is based on justice and equality. This positive perception of Dutch society leads to equating democracy with justice and equality. The formulation of democracy as the continuation of Dutch society becomes the hegemonic discourse in the political life of IGMG. This life is dominated by new norms and values and thus meanings. It is through this new formulation that IGMG gives meaning to the political world. While it is Islam that is the hegemonic discourse in the religious and cultural sphere, it is democracy that takes over the hegemonic role in the political sphere. In order to avoid a conflict between these two systems of meaning, 
religious content is reinterpreted. IGMG's understanding of sharia constitutes a break with the Islamist tradition. It is not associated with establishing an Islamic state that is ruled by Islamic law anymore; rather it is interpreted as "the conducts that a Muslim carry out in his/her daily life to gain the consent of Allah" (Interview with Dursun, June 26, 2006).

Dursun is a 53 year old IGMG member. As a young man, he used to be very active in IGMG but now due to his health problems he lives a quiet life he says. He lives in Amsterdam with his wife and his three children. His interpretation of sharia and jihad are important indicators of the dynamic relationship between the religious symbols, their interpretation and the reality as it is perceived by the believer.

It is true that Islamic faith attributes great importance to jihad and sharia. You should be willing to fight for your religion and establish the rule of God in this world. But you have to interpret these commands in the modern context. May be the only way of waging jihad was by sword in the past but today teaching Islam to somebody who has misunderstanding about your religion is the jihad. You can fight for your religion by being a good Muslim. Everyday we are fighting for it. In the face of degeneration, moral erosion, we are fighting to be moral, ethical. This is the real jihad. The same applies to sharia. Sharia means path to the water source as a term. I interpret God's word thus: water source is an Islamic life. There is more than one path to the source. Raising your children in line with Islam is establishing shariat, the rule of God in this world. Planting the love of God in their hearts is establishing his rule and to achieve this you don't need a theocracy. Look at my life. I live in a democracy and yet could be able to establish sharia and wage jihad everyday (Interview with Dursun, June 26, 2006).

Islam in the Dutch context constitutes one of many signifiers. Despite its dominant role among them, it is not the hegemonic discourse in every aspect. IGMG member's meaning world is dominated by two systems of meaning, one provided by Islam as a religio-cultural signifier, the other provided by democracy as a political signifier. The harmony among these two systems of meaning are achieved through 
formulation of an Islamist ideology in which Islam is not the master signifier but a religio-cultural signifier that defines Islam as faith and a way of life.

\subsubsection{Islamism as a Democratic Participation Strategy}

Islamism is used as a strategy to participate in the democratic structure of the Dutch society. IGMG is organized as a civil society institution and it provides a zone of voluntary associative life beyond family and ethnic affiliations for its members. It has not only an internal structure that is reliant on democratic procedures, but also a political discourse that is couched in the language of democratic principles. It encourages its members to get involved into the Dutch society socially and politically. Canan Uyar, the chairperson of IGMG's Women's Federation, states that they organize events to inform their members about the candidates and the political process during Dutch elections and try to raise awareness about the importance of political participation. The organization cooperates with local Dutch authorities on developing programs that are designed to enhance immigrants' integration and involvement into the Dutch society. Many of their activities and projects are funded by the Dutch government. Uyar says that they are in constant contact with Dutch authorities. The organization holds regular meetings with ministries including Ministry of Internal Affairs, Ministry of Justice, Ministry of Education and Social Affairs and provides the Dutch authorities feedback on issue pertaining to Muslim community (Phone interview with Canan Uyar, February 6, 2008).

In IGMG's discourse, Islam is not treated as a private matter which should be defined as the relationship between God and the believer. On the contrary, Islamic identity provides the Muslim immigrant community the means to exist in Dutch public space. It is through the Islamic identity that the Muslim immigrant community finds a 
channel of contact and communication with the Dutch authorities. Contrary to traditional Islam which separates the public and the private realm and confines Islam to the latter, IGMG's discourse rejects this separation and treats both realms as each other's continuation. Mehmet has been a spokesperson for IGMG since 1993. His statements clarify the stance of IGMG on the nature of the relationship between state and individual/society.

The state is not an end in itself. It is just the means to achieve a just and peaceful society which is the sole aim that we try to achieve in private lives. So there is no distinction between the public and the private, they are each other's continuation (Interview with Mehmet, 28 June 2006).

Different types of governments are considered as different attempts to achieve the same end, to satisfy the demands in the private realm. Thus IGMG rejects the separation of these realms and argues that the rules that govern the private realm govern the public realm as well. Although German IGMG also rejects the separation, it defines an affective relationship between state and individual/society. By defining Islam as faith, way of life and a political order, it envisions the state as the reflection of Islamic ethos. IGMG in the Netherlands, on the other hand, defines the relationship between state and individual/society in a pragmatic way. While an Islamic ethos governs the religio-cultural life, a democratic ethos governs the political sphere. By formulating the state-society relationship on pragmatic grounds, IGMG avoids the clash between its Islamist discourse and participation in the democratic process. Within the framework of this discourse where Islam constitutes the religio-cultural signifier and democracy constitutes the political signifier, Islamism provides the means for participation in the democratic 
process. Both the IGMG elite and the members see IGMG as a way of communication with the Dutch authorities, a way of affecting public outcomes.

When I asked her why she became involved with IGMG, Canan Uyar said the following:

To me, being a member of Milli Gorus is a way of democratic participation in the Dutch society. IGMG supports women's involvement in society at all levels. Through IGMG and the projects that we establish with the help of Dutch government I can contribute to the wellbeing of the society in which I live. I can be a Muslim woman and still play an active role in public life, which is something that you cannot find in many countries of the world. As an individual, you have limited opportunities to establish communication with the authorities. But if you are an organization that represents a group of people, especially a group of Muslims, you get recognized by the authorities. This way we can raise our concerns and be part of the public life (Interview with Canan Uyar, June 6, 2007).

Ramazan and Yunus make similar arguments. They are 29 and 34 years old respectively. They have been very active in the IGMG's Youth Department. They say that when you have an institutional affiliation you receive recognition from the Dutch authorities. Ramazan says "There is religious freedom in this country. According to the law, the state has to support your initiatives as a religious community. IGMG provides us the institutional infrastructure to get involved politically" (Interview with Ramazan, 8 June, 2007).

Organizing under the Islamic identity provides IGMG the legitimacy it needs both in the eyes of Dutch authorities and the Muslim immigrant community. IGMG members exist in Dutch public space not despite their Islamic identity but because of it. The Islamism that is formulated by IGMG reflects the learning process that took place within IGMG as a result of its experience with the Dutch society, in which democratic principles were internalized. A balance between a Western understanding of democracy and an 
Islam oriented life has been reached by the IGMG members and this balance has been institutionalized by IGMG's discourse. Having developed under the conditions of peaceful coexistence, Islamism has become a strategy of democratic participation in the Dutch context. It has provided its followers the opportunity to exist as Muslims in a Western context and become actors who participate in the making of society.

\subsection{EXPLAINING THE DIFFERENCE: A CONTEXTUAL ARGUMENT}

IGMG's public profile and views in regards to democracy, secularism, and the host society show considerable differences in Germany and the Netherlands. While IGMG in Germany displays a critical approach towards the West and its institutions such as democracy and secularism and offers Islamism as an opposition strategy, IGMG in the Netherlands embraces democracy and incorporates it into its Islamist discourse as a way of participation in the Dutch society. How do we explain the different paths taken by the members of the same immigrant community who had similar socio-economic backgrounds before coming to Europe, came to Europe under the same conditions at around the same time and had no prior engagement with any Islamist movement? The differences in IGMG's institutionalization, public profile and views suggest that the context of the host society not only shapes the relationship between IGMG and the host community but also the form the Islamist rhetoric takes. While discrimination and exclusion by the host society lead to feelings of insecurity, alienation and thus radicalization within Islamism in Germany, inclusive policies that are designed to incorporate immigrants in the host society result in an optimistic integrationist Islamist discourse that embraces democratic ideals in the Netherlands. 
Radicalization is a process of alienation, rejection and de-legitimization (Slootman \& Tillie 2006). It is strongly connected to identity formation. The question of "Who am I?" lies at the heart of the radicalization process. The answers given to this question determine the place of the group vis-à-vis the wider society. The social environment plays the leading role in providing the answers to the group. Definitions of ingroup and outgroup, the attitudes towards "the other" that prevail in society are essential factors in conceptualization of the self. They can either lead to insecurity and alienation or a positive identification with the social environment. While psychological insecurity and alienation from the wider society make groups defensive, rigid in thought and less tolerant for deviance from the group, a positive self-image is important for developing not only self-confidence but also confidence in the system. A group or an individual who has more attachment to the surrounding and the wider society through shared experiences or identification attributes legitimacy to the wider society and the rules that are governing it. Therefore, it is important that people gain confidence in the democratic rule of law and have opportunities to turn their dissatisfaction into political action. A group which believes that government does not function and protect its interests will withdraw from the society and try to change it outside the political system (Slootman \& Tillie 2006).

Socio-economic and political marginalization of the Turkish immigrant community in Germany and the perception of exclusion by the German society have created a sense of inequality, injustice and psychological insecurity among the immigrant community. They see injustice in their surrounding and they feel that they are measured by a double standard not only in the opportunities they have in society but also in the 
image the society have of them. German society and its institutions are seen as biased. They believe that this bias prevails at all levels of German society including the police which are believed to "cover up the racist attacks against Muslims by Germans" (IGMG Perspektive 2005). They do not believe that their rights and interests are protected by the German government and consider themselves as victims of an unjust and unequal system. The social, economic and political disadvantages they face are seen as structural and proof of the irreconcilability between Muslims and non-Muslims and the oppressive nature of the West (Slootman \& Tillie 2006). Lacking citizenship rights, they do not have legitimate ways of expressing their frustrations. Thus they turn to IGMG. The marginal status of Muslims in German society has resulted in the development of criticism of the German society which is formulated in ideological terms and aspects of a counterhegemonic discourse. IGMG has developed an alternative ideological system in which the legitimacy of the German system is called into question and converted frustration and anger about the functioning of the system into a de-legitimizing counter-hegemonic ideology.

IGMG in the Netherlands, on the other hand, is oriented towards participation in society. The prevailing insecurity in the German context does not exist in the Dutch context. Despite the changes after September $11^{\text {th }}$, the majority of IGMG members still view the Dutch society as a tolerant society in which different religions and races can coexist peacefully. They do not consider Muslims and non-Muslims as diametrically opposed entities but rather as different parts of the same whole. They do not feel socially or politically isolated. Having Dutch citizenship, they believe that they can participate in the economy and politics on equal terms with the rest of the Dutch society. They do not 
think that they have to give up their religious identity to survive in the Netherlands. Due to this trust in the wider environment, IGMG members could be able to develop an Islamic identity which provides an essential psychological anchor and yet is not in conflict with the host society. Thus, the problems that are encountered are not Islamicized. The unemployment among the immigrant population, for example, is not interpreted as the result of the discrimination of the Muslims by the Dutch society but rather as "the result of the general state of the Dutch economy" (Interview with Huseyin, June 28, 2006). The legitimacy that is attributed to democracy is in fact the legitimacy attributed to the Dutch society by IGMG. The perception that their rights and interests are protected by the Dutch institutions has resulted in confidence in the democratic process. The discourse of Islamism has become one that emphasizes the possibilities that can be pursued within the democratic framework. They reject certain aspects of Dutch society and wish to address their concerns. Being Dutch citizens, they can do so in the Dutch political system. They have legitimate ways of expressing their frustrations. They view IGMG as a channel through which they can express their frustrations. Being Muslim in the Dutch context is not a source of frustration but is an inspiration for socially and morally just political ideals and an effective way of organizing and raising demands at the local and national level.

Comparison of the German and the Dutch cases reveals that Islamism is not "a statement of demarcation made by immigrant Muslims who consciously seek to avoid integration and whose way of life subscribes to certain norms and values that are at odds with those of the majority of society" but it is in fact shaped by the rules, laws, regulations and attitudes of the host society. While it can become a bridge between the 
Muslim community and the host society and be used as a democratic participation strategy under the conditions of tolerance, equality and justice, it can develop as a counter-hegemonic force, an opposition strategy in the face of discrimination and exclusion. 


\section{CHAPTER 6}

\section{ANALYSIS OF SURVEY FINDINGS}

The purpose of this chapter is to analyze the survey data that was collected between 2004 and 2007 in Germany and the Netherlands. The extent of marginalization is examined by country in order to see whether Germany has significantly higher marginalization than the Netherlands. Second, the levels of radicalization are compared to establish if Germany has higher radicalization than the Netherlands. Lastly, total marginalization and total radicalization variables are created by summing all the indicators for each group. If we can observe a correlation between marginalization and radicalization we can conclude that people who are highly marginalized are also highly radicalized and vice versa. The distribution of the variables in Germany and the Netherlands are analyzed using graphs and $\mathrm{T}$ test.

Social marginalization is defined as "an external social position, of isolation of the individual or groups, with a limited access to economical, political, educational and communicational resources of the community" (The law adopted by the Romanian Parliament in 28 February 2002, www.hurriyetim.com, November 25, 2004). According to the definition used in this study, social marginalization has five pillars: social, economic, political, educational and cultural. A socially marginalized group/person is not only isolated socially but also economically, politically, educationally and culturally and scores high on all the five variables. Since I could not gather enough data about educational marginalization, it will be discarded from the analysis. Therefore, four different variables were created under the social marginalization variable, total marginalization representing the sum of all these different variables. 
Radicalization is measured by eight different variables: anti-tolerance, inequality, anti-Western, anti-democracy, non-secular, puritanical, monoethnic, anti-integrationist. The main indicators for radicalism were borrowed from a report prepared by the Ministry of the Interior of the Dutch Government under the title of From Dawa to Jihad: The Various Threats from Radical Islam to the Democratic Legal Order. A person/group is considered radical if he/she/it scores high on all these eight variables. Total marginalization represents the sum of all these variables.

\subsection{MARGINALIZATION by COUNTRY}

Four marginalization variables were created by summing all the scores related to questions falling under the specific marginalization category, ie. Social marginalization, cultural marginalization, economic marginalization and political marginalization. . (Please see the methodology chapter for further information on survey and variables). Resulting variables are total social marginalization, total cultural marginalization, total economic marginalization and total political marginalization. Total social marginalization, total cultural marginalization, total economic marginalization and total political marginalization are indexes which bring together various indicators that reflect social, cultural, economic and political marginalization respectively. Total social marginalization consists of nine indicators that are measured by questions A5 through A13. Total cultural marginalization includes four indicators which are reflected in questions A17 through A20. Total economic marginalization is composed of three indicators, questions A21 through A23; political marginalization includes three indicators that are measured by questions A24 through A26. For each variable, we produced a bar graph showing how many people, among those interviewed in Germany and Holland, 
scored a particular value of each of the five variables. In each graph, variable values are reflected on the horizontal axis, while frequencies are reflected on the vertical axis.

Table 6.1 provides group statistics for both countries. By simply looking at the numbers we can notice that there is a difference between the average scores for each variable across the country. We can learn more about how they are distributed across different groups if we look at how they are spread in the graphs.

Table 6. 1 Group Statistics of Marginalization for Germany and the Netherlands

\begin{tabular}{|c|c|c|c|c|c|}
\hline & Where do you live? & $\mathrm{N}$ & Mean & $\begin{array}{l}\text { Std. } \\
\text { Deviation }\end{array}$ & \begin{tabular}{|l} 
Std. \\
Error \\
Mean
\end{tabular} \\
\hline & Germany & 50 & 30.54 & 2.99 & 0.42 \\
\hline Vargmanzation & The Netherlands & 46 & 25.60 & 4.24 & 0.62 \\
\hline & Germany & 53 & 12.90 & 1.95 & 0.26 \\
\hline & The Netherlands & 53 & 10.26 & 1.53 & 0.21 \\
\hline Total & Germany & 17 & 9.76 & 2.63 & 0.63 \\
\hline Marginalization & The Netherlands & 29 & 8.20 & 2.51 & 0.46 \\
\hline Total Political & Germany & 53 & 10.83 & 1.94 & 0.26 \\
\hline Marg & The Netherlands & 53 & 8.00 & 1.68 & 0.23 \\
\hline
\end{tabular}




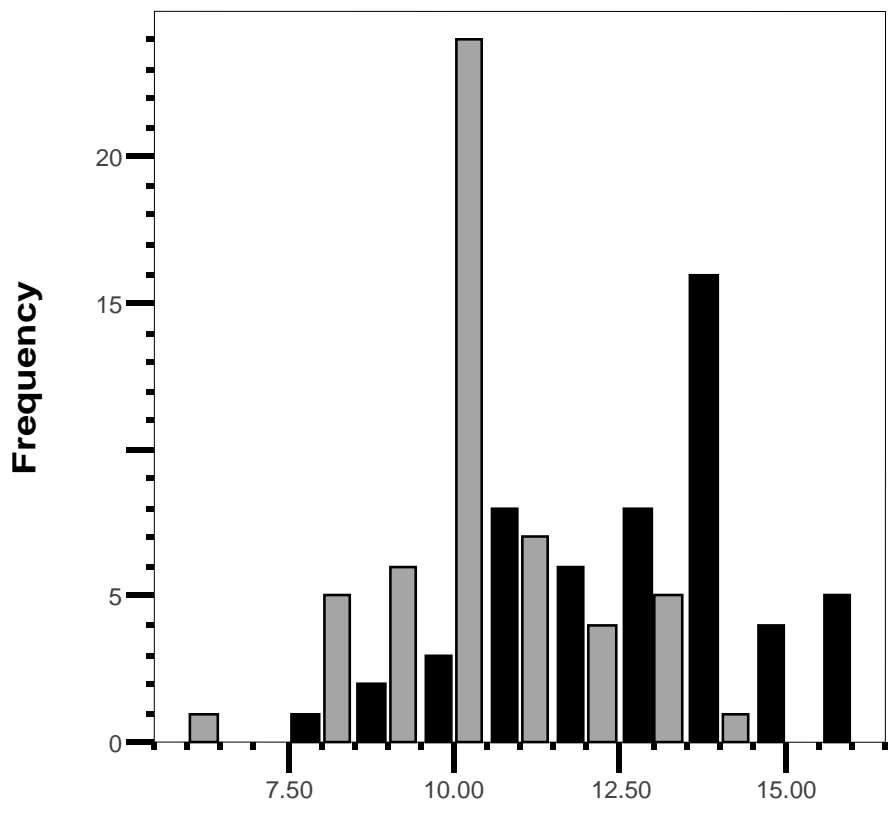

Germany

The Netherlands

Bars show counts

Total Cultural Marginalization

Figure 6. 1 Total Cultural Marginalization Indicators

Total cultural marginalization index was created using questions A17, A18, A19 and A20 (Please see the appendix for the questions). If we look at Figure 6.1, we can see that overall there are higher levels of cultural marginalization (black bars) in Germany. The modal category in Germany is more to the right in the graph, which shows that the biggest group in Germany is more culturally marginalized than the biggest group in the Netherlands. In other words, Milli Gorus members in Germany tend to have higher total cultural marginalization than Milli Gorus members in the Netherlands.

The questions that were asked for the cultural marginalization variable were designed to understand if Milli Gorus members are culturally part of the host society, whether they follow the host country news more often than they follow Turkish news. The results indicate that the majority of the Milli Gorus members in Germany watch Turkish channels and read Turkish newspapers more than German channels and 
newspapers while their Dutch counterparts display an opposite tendency. Milli Gorus members in the Netherlands tend to watch Dutch channels and follow Dutch news more often than Turkish channels and news. The German Milli Gorus's strong cultural ties with Turkey might be explained by their lack of proficiency in German language accompanied by their perceived isolation from the German society. Although second and third generation Turks speak German better than the first generation, the perception that they are not and will never be part of the German society results in establishing closer ties to Turkey. Since Germany has officially denied being an immigration country, she considered Turkish immigrants as "guest worker" who will return to Turkey eventually. Therefore, Germany did not deem it necessary to establish programs that would teach Turkish workers German. As a result, a majority of the first generation workers did not learn German. Lack of proficiency in German accompanied by the perception of exclusion has resulted in their unwillingness to participate in German society culturally.

My second variable is total economic marginalization. Total economic marginalization index was created using questions A21, A22 and A23 (Please see the appendix for the questions). Looking at Figure 6.2., we can see that although the difference between the countries is not as clear as the difference in cultural marginalization, these are indications that economic marginalization among the Milli Gorus members is somewhat higher in Germany than the Netherlands. The possible reason for this pattern might be that since Germany does not allow dual citizenship, majority of Milli Gorus members do not have German citizenship which makes them vulnerable in the job market. Their options in the job market are limited. 55 percent of 
those that were interviewed are unemployed. Of the 45 percent who are employed, 70 of them are blue-collar workers.

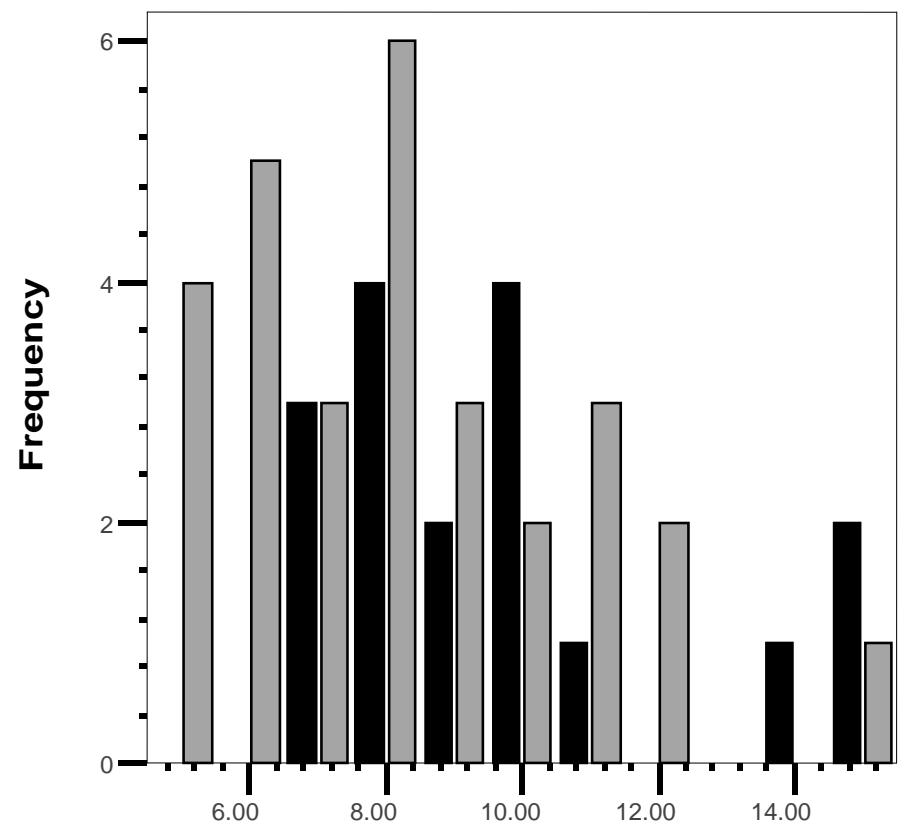

Germany

The Netherlands

Bars show counts

Total Economic Marginalization

Figure 6. 2 Total Economic Marginalization Indicators

The next index was created using questions A24, A25, and A26 (Please see the appendix for the questions). Figure 6.3 indicates that the modal category in Germany is more to the right than the modal category in the Netherlands which shows that the biggest group in Germany is more politically marginalized than the biggest group in the Netherlands. Therefore, we can clearly conclude that political marginalization among Milli Gorus members is higher in Germany than the Netherlands. 


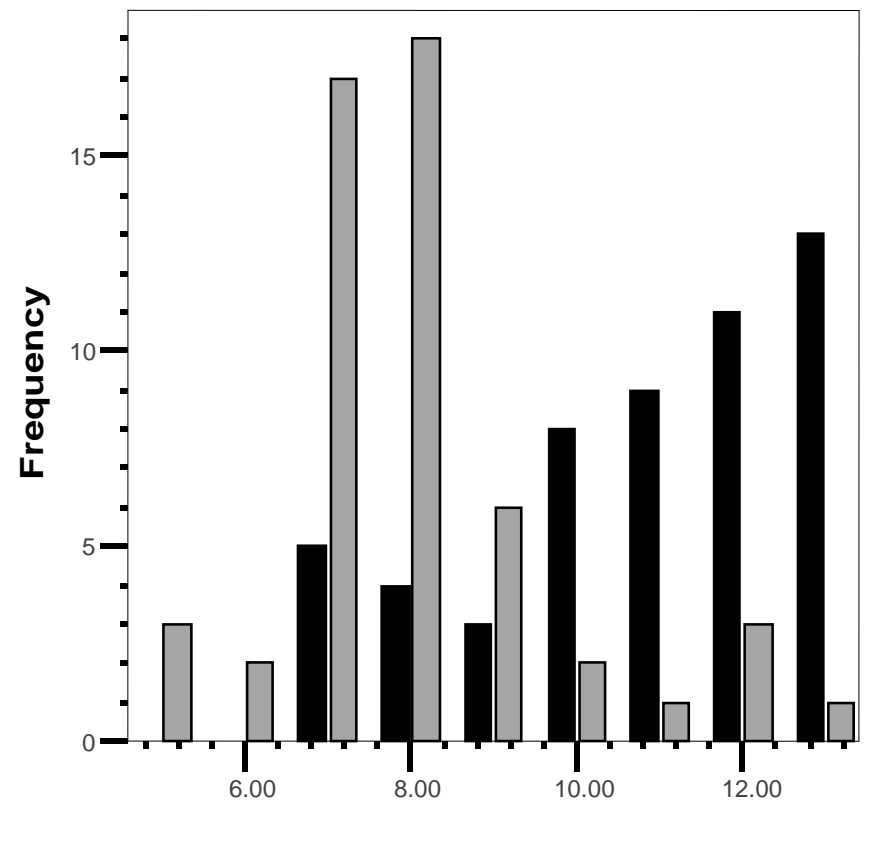

Germany

The Netherlands

Bars show counts

Total Political Marginalization

Figure 6. 4 Total Political Marginalization Indicators

This pattern can be explained by the lack of German citizenship among Milli Gorus members in Germany. Only 25 percent of those Milli Gorus members in Germany who were interviewed had German citizenship while 88 percent of Milli Gorus members in the Netherlands had Dutch citizenship. Having citizenship of the host country not only automatically integrates Milli Gorus members into the political structure of the host society through voting, it also creates a sense of belongingness and thus results in greater interest in the political process. German law does not allow dual citizenship for adults, which leaves its immigrant population which has been living in Germany for more than forty years without citizenship. The majority of the respondents stated that they did not want to apply for German citizenship because they did not want to give up their Turkish nationality since it would mean giving up inheritance rights and right to buy property in Turkey. Thus, keeping Turkish nationality is a practical and psychological necessity for 
them. In the Netherlands, on the other hand, the laws provide the immigrants the right to retain their first nationality. As a result, 88 percent of Milli Gorus members have Dutch nationality, which makes them politically less marginalized than their German counterparts.

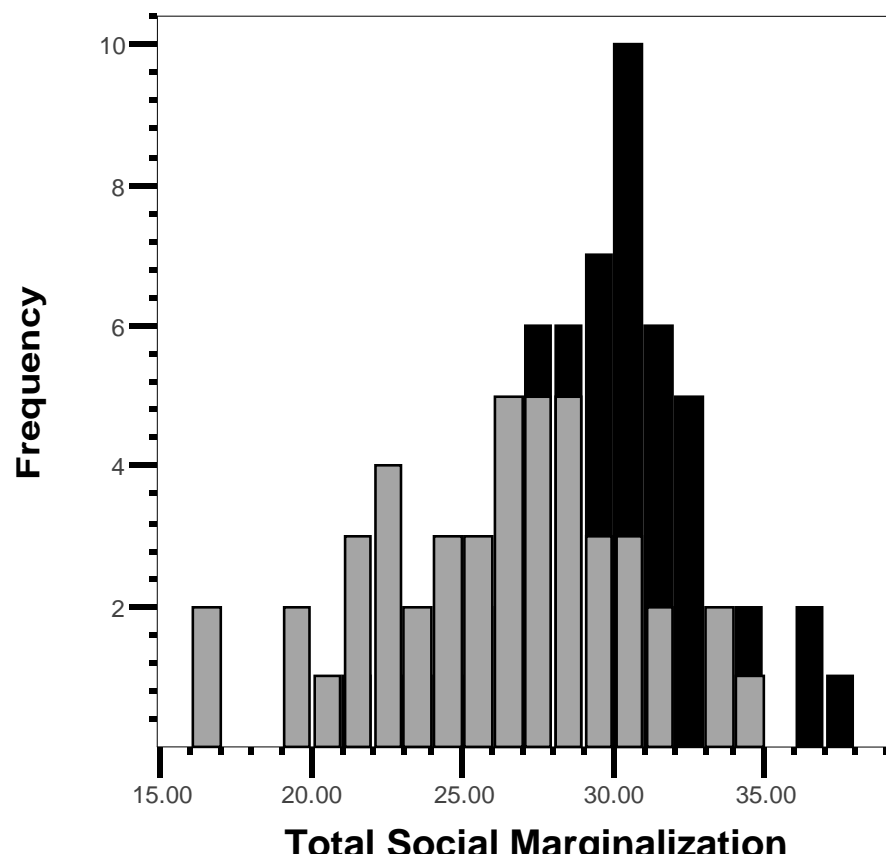

Germany

The Netherlands

Bars show counts

Figure 6. 5 Total Social Marginalization Indicators

Total social marginalization index was created using questions A5, A6, A7, A8, A9, A10, A11, A12 and A13 (Please see the appendix for the questions).The questions that were asked in this section can be grouped into two. The first group was designed to understand the perceptions of Milli Gorus members, whether they perceive themselves as part of German or Dutch society. They were asked to identify themselves with a society or country. The second group of questions consisted of questions that were less direct such as how often they meet German/Dutch families, whether they spend more time with Turkish families etc. 
Figure 6.4 clearly demonstrates that Milli Gorus members in Germany are socially more marginalized than Milli Gorus members in the Netherlands. Milli Gorus members in Germany identify themselves less with German society and more with Turkey while Milli Gorus members in the Netherlands identify themselves more with Dutch society and less with Turkey. Milli Gorus in Germany spends less time with German families while they spend time with Turkish families or Turkish friends from the mosque almost everyday. They display more skepticism toward the German society stating that they do not think their rights and interests are protected by German society or its institutions. In the Netherlands, on the other hand, we see an opposite trend. The reason for this pattern might be the exclusion of the immigrant communities by the host societies which are reflected in their immigration and citizenship laws. Germany has traditionally adopted the argument that she was not an immigration country and institutionalized this belief with its exclusionary immigration and citizenship laws, which has created a perception among Milli Gorus members that they were "unwanted" and resulted in a social distance between them and the German society. Despite the recent changes in perceptions due to September $11^{\text {th }}$ attacks, the Netherlands is still known for its tolerant approach toward its ethnic minorities among Milli Gorus members. They consider the rights that are provided to Muslims by the Dutch government such as the right to establish their own schools, the right to dual citizenship, the Dutch government's willingness to consult Muslim organizations on issues related to Muslims as proofs of Dutch society's respect for Islam. This trust in the host society has created a social environment where Milli Gorus members are willing to interact with the Dutch society socially. 
Next I use T-test to assess whether the average level of marginalization relative to each of the five marginalization dimensions I created is significantly different in the Netherlands and Germany. Tests results are reported in Table 6.2.

The $\mathrm{p}$ value for total social marginalization, total cultural marginalization and total political marginalization are 0 whereas the $\mathrm{p}$ value for total economic marginalization is .052 , meaning that marginalization is significantly higher in Germany for every dimension except total economic marginalization at .05 level and all variables would show significant difference at .1 significance level. The sample that I used does not provide conclusive results for total economic marginalization.

\subsection{RADICALIZATION by COUNTRY}

As I did for the marginalization variables, I created eight radicalization variables by summing all the scores related to questions falling under a specific radicalization category. Resulting variables are total Puritanism, total monoethnicism, total antiintegrationism, total anti-tolerance, total inequality, total anti-westernism, total antidemocracy and total non-secularism. For each of these radicalization variables, I analyzed the differences between Holland and Germany using graphs and t-tests Graphs are similar to those in the marginalization section, with variable values in the horizontal axis and frequencies in the vertical. Results are concordant in showing a higher level of radicalization in Germany than the Netherlands.

Table 6.3 provides group statistics for both countries. It indicates that there is a difference between the average scores for each variable across the country. We can learn more about how they are distributed across different groups if we look at how they are spread in the graphs. 
Table 6. 2 Independent Samples Test of Marginalization

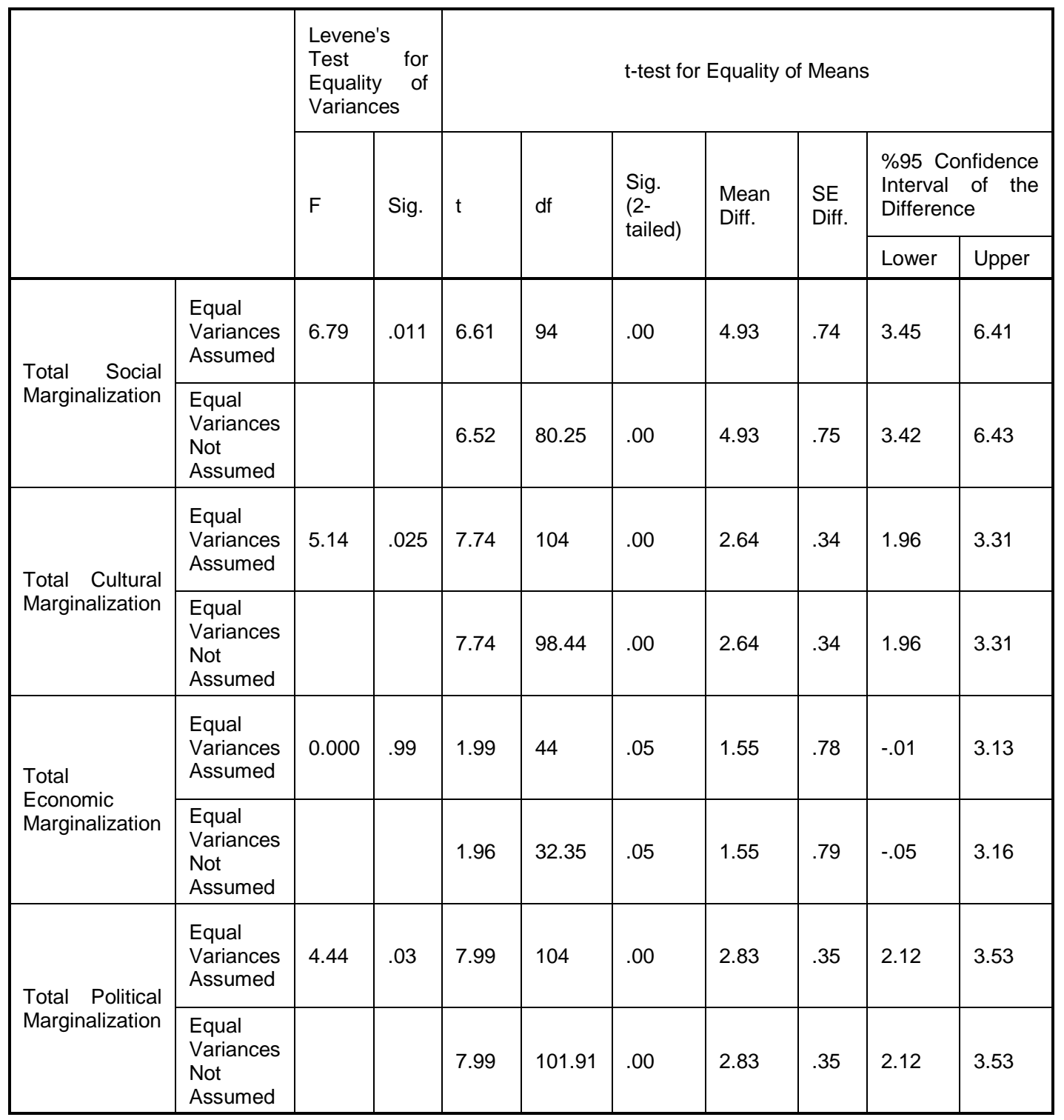

Total anti-democracy index was created using questions A42, A43, A44, A45, A46, A47, A48, and A49 (please see the appendix for the questions). The questions were designed to reveal the respondents' attitudes towards democracy and whether they have faith in democratic institutions. Figure 6.5 indicates that the modal category in Germany is more to the right than the modal category in the Netherlands which shows that the biggest group in Germany has less faith in democracy than the biggest group in the Netherlands. 
Table 6. 3 Group Statistics of Radicalization for Germany and the Netherlands

\begin{tabular}{|c|c|c|c|c|c|}
\hline & & $\mathrm{N}$ & Mean & \begin{tabular}{|l} 
Std. \\
Deviation
\end{tabular} & \begin{tabular}{|l} 
Std. Error \\
Mean \\
\end{tabular} \\
\hline \multirow{2}{*}{ Total Puritanism } & Germany & 53 & 2.83 & 1.20 & .16 \\
\hline & $\begin{array}{l}\text { The } \\
\text { Netherlands }\end{array}$ & 53 & 2.39 & 1.16 & .16 \\
\hline \multirow{2}{*}{$\begin{array}{l}\text { Total } \\
\text { Monoethnicisim }\end{array}$} & Germany & 53 & 1.67 & .47 & .06 \\
\hline & $\begin{array}{l}\text { The } \\
\text { Netherlands }\end{array}$ & 53 & 1.33 & .47 & .06 \\
\hline \multirow{2}{*}{$\begin{array}{l}\text { Total } \\
\text { Anti- } \\
\text { Integrationism }\end{array}$} & Germany & 53 & 1.16 & .37 & .05 \\
\hline & $\begin{array}{l}\text { The } \\
\text { Netherlands }\end{array}$ & 52 & 1.03 & .19 & .02 \\
\hline \multirow{2}{*}{$\begin{array}{l}\text { Total } \\
\text { Anti -Tolerance }\end{array}$} & Germany & 53 & 17.67 & 1.92 & .26 \\
\hline & $\begin{array}{l}\text { The } \\
\text { Netherlands }\end{array}$ & 49 & 14.55 & 2.87 & .41 \\
\hline \multirow{2}{*}{ Total Inequality } & Germany & 53 & 7.35 & 1.79 & .24 \\
\hline & $\begin{array}{l}\text { The } \\
\text { Netherlands }\end{array}$ & 53 & 5.33 & 1.59 & .21 \\
\hline \multirow{2}{*}{$\begin{array}{l}\text { Total } \\
\text { Anti-Westernism }\end{array}$} & Germany & 53 & 4.30 & 1.20 & .16 \\
\hline & $\begin{array}{l}\text { The } \\
\text { Netherlands }\end{array}$ & 52 & 4.07 & .70 & .09 \\
\hline \multirow{2}{*}{$\begin{array}{l}\text { Total } \\
\text { Anti-Democracy }\end{array}$} & Germany & 51 & 20.29 & 3.32 & .46 \\
\hline & $\begin{array}{l}\text { The } \\
\text { Netherlands }\end{array}$ & 45 & 16.20 & 2.95 & .44 \\
\hline \multirow{2}{*}{$\begin{array}{l}\text { Total } \\
\text { Non-Secularism }\end{array}$} & Germany & 53 & 12.05 & 2.37 & .32 \\
\hline & $\begin{array}{l}\text { The } \\
\text { Netherlands }\end{array}$ & 47 & 11.21 & 2.32 & .33 \\
\hline
\end{tabular}

Therefore, we can conclude that Milli Gorus members in Germany are more antidemocratic than their Dutch counterparts.

The details of Milli Gorus's views in both countries and the reasons for those 
views are provided in Chapter 5 but it should be emphasized here that these variables are different indicators of radicalism.

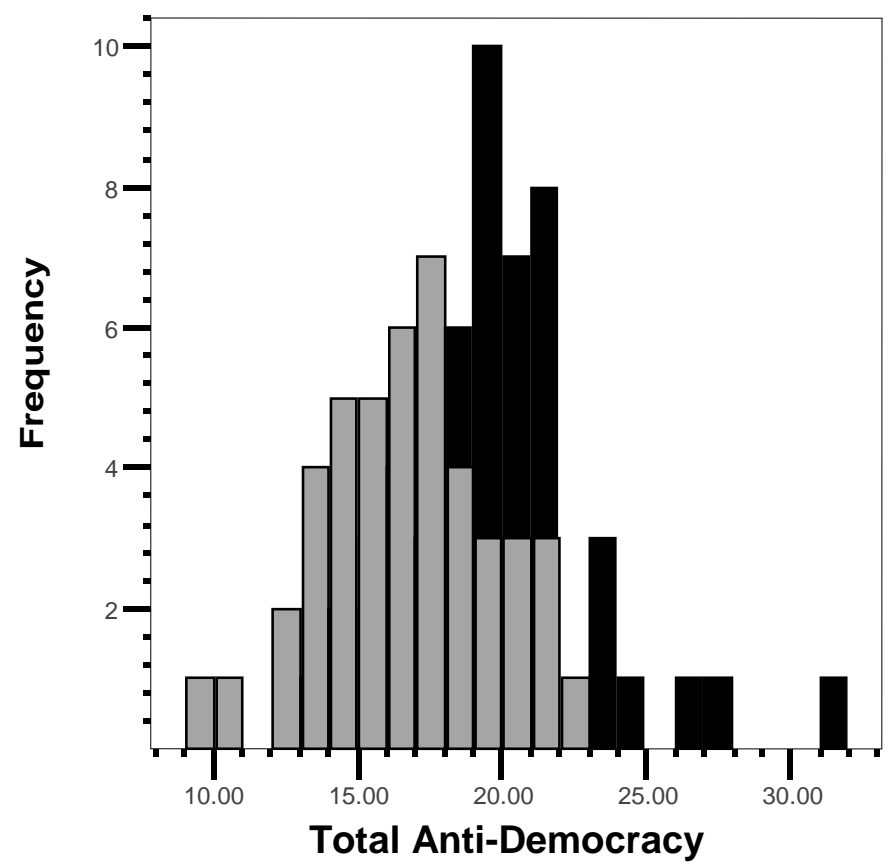

Germany

The Netherlands

Bars show counts

Figure 6. 6 Total Anti-democracy Attitudes

A radical group is defined as one that is hostile to Western notions of democracy and secularism, has no tolerance for a multi-ethnic or multi-religious society. Germany's score on each of the radicalism variables is higher than that of the Netherlands, indicating a higher level of radicalism in Milli Gorus in Germany than the Dutch Milli Gorus. This variance is explained by German Milli Gorus's high level of skepticism towards the German society as a result of real and/or perceived discrimination by the German society. Feeling excluded from the system at political, social and economic levels, Milli Gorus members in Germany have developed an understanding that Western notions of democracy are incapable of delivering justice. This skepticism towards German society is 
not only reflected in Milli Gorus's hostile approach toward democracy but also towards secularism and a multi-ethnic/multi-religious society, which results in Milli Gorus's withdrawal from both the democratic process and German society in general.

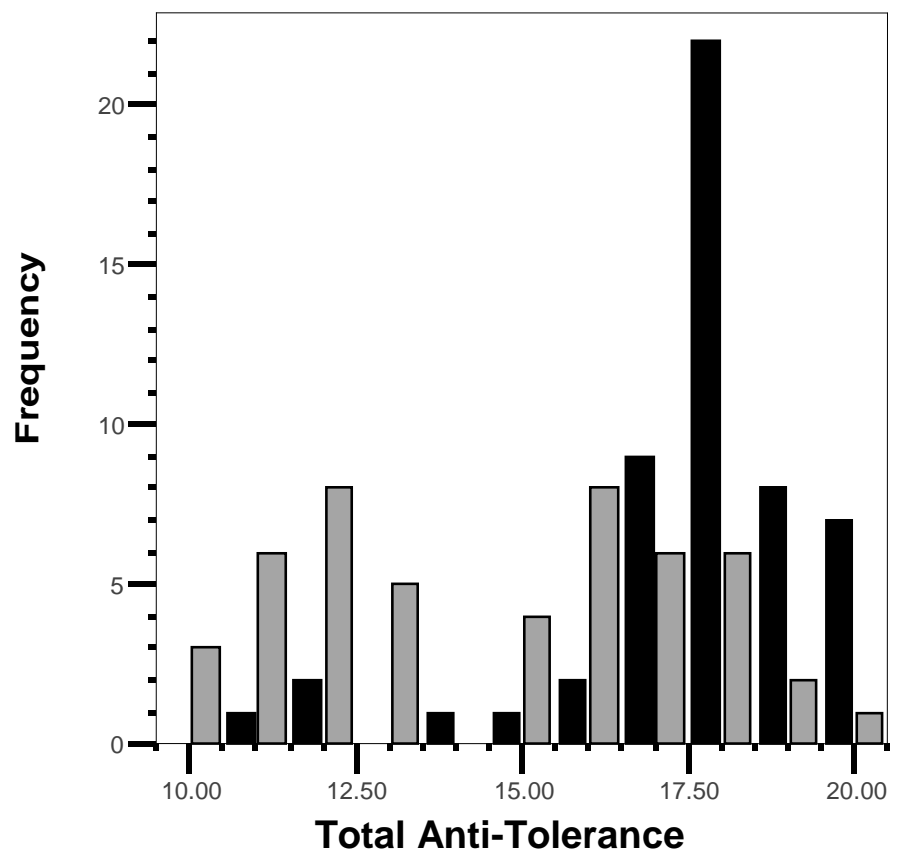

Germany

The Netherlands

Bars show counts

Figure 6. 7 Total Anti-tolerance Attitudes

Total anti-tolerance index was created using questions A27, A28, A29, A30, A31, A32, A33, A34, A35, and A36 (please see the appendix for the questions). The questions in this section were designed to reveal the level of tolerance of the respondents towards people from different ethnic, religious, cultural background and sexual orientation. According to Figure 6.6 the modal category for Germany is more to the right (black bars) than the modal category for the Netherlands indicating that the level of intolerance towards people from different ethnic, religious, cultural background and sexual orientation is higher among Milli Gorus members in Germany than in the Netherlands. It 
is essential to note that the majority of Milli Gorus members in Germany displayed severe hostility towards Israel and Jews. They interpret the Israeli Palestinian conflict as the "oppression of Muslims by Zionist forces of which the West constitutes an important part" (Interviews in Cologne, May-July 2006). Milli Gorus in the Netherlands, on he other hand, display lower levels of anti-semitism and is more tolerant towards different ethnicities and religions.

Total anti-Westernism index was created using questions A40 and A41 (please see the appendix for the questions). Figure 6.7 shows that Germany has somewhat higher total anti-West values than the Netherlands but the difference is not easily distinguishable. Milli Gorus members in both countries hold anti-western beliefs but antiwesternism is slightly higher among the German Milli Gorus than the Dutch Milli Gorus. The closeness of the anti-westernism scores might be explained by looking at the questions asked to measure anti-westernism.

There are two questions in this index. The first question asks the respondent what they think the biggest danger is for the Turkish youth in Europe: rising unemployment, losing of their ties to Turkey or adopting Western ideas and life style. 69 percent of Milli Gorus members in the Netherlands and 73 percent of them in Germany stated that the biggest danger facing the Turkish youth in Europe was adopting Western ideas and life styles.

Despite the same answer given to this question by Milli Gorus members in both countries, their conceptualization of Islam is quite different. This difference could not be revealed by question A40 but was deducted from the personal interviews. Question A40 just shows the only common point in German and Dutch Milli Gorus members' 
understanding of Islam which considers Islam as a cultural signifier. The details of German and Dutch Milli Gorus's conceptualization of Islam are provided in Chapter 6.

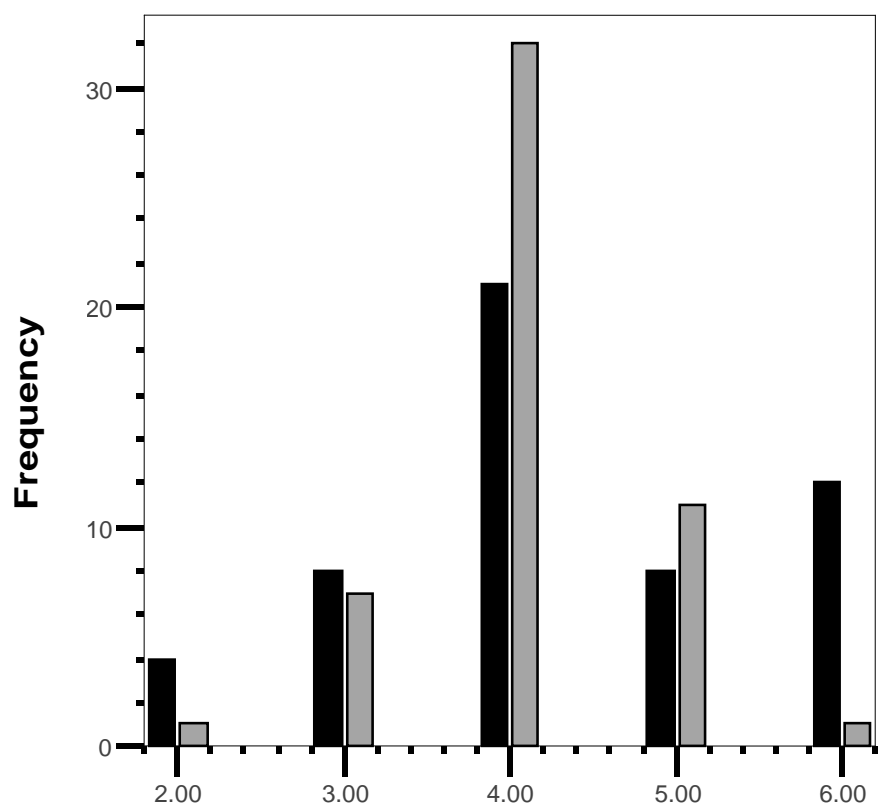

Germany

The Netherlands

Bars show counts

Total Anti-Westernism

Figure 6. 8 Total Anti-Western Attitudes

The second question in the index provides the real insight into the level of radicalism of Milli Gorus. The second question asks the respondents to choose one of three kinds of attitudes concerning the society they live in: make reforms, keep the status quo or change the society with a radical revolution. While only 3 percent of Dutch Milli Gorus members chose the radical revolution as a way of changing society, 25 percent of Milli Gorus members in Germany stated that the society needed a radical revolution.

Total non-secularism index was created using questions A50, A51, A52, and A53. The questions that were asked in this section aim to understand what the respondents think about the role of religion in politics. Figure 6.8 indicates that Milli Gorus 
Germany's level of opposition to secularism is higher than that of Milli Gorus in the Netherlands.

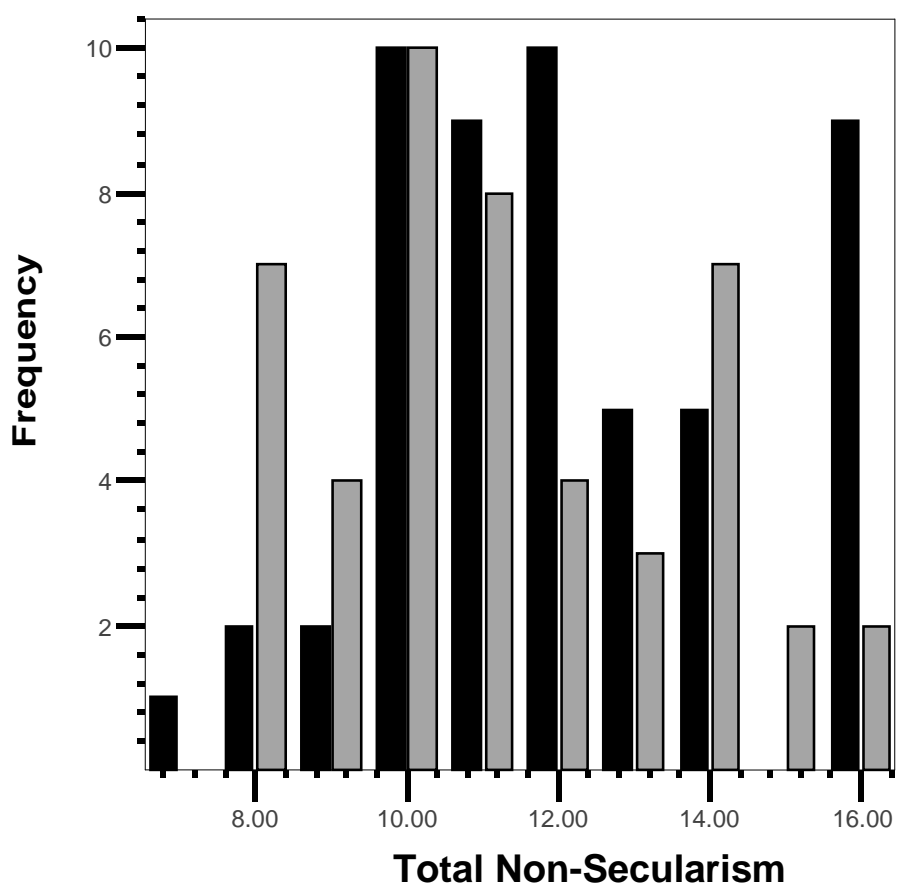

Germany

The Netherlands

Bars show counts

Figure 6. 9 Total Non-secular Attitudes

Total inequality index was created using questions A37, A38 and A39. The questions that were asked in this section aim to understand the respondent's approach towards the equality of men and women in job market, in university education and public life. German Milli Gorus's total inequality score is higher than Dutch Milli Gorus's total inequality score. When asked about their beliefs on the equality of men and women, German Milli Gorus members demonstrated a negative attitude towards the equality of men and women whereas the Dutch Milli Gorus members seemed to believe in providing equal opportunities for men and women in job market, university education and public life. 


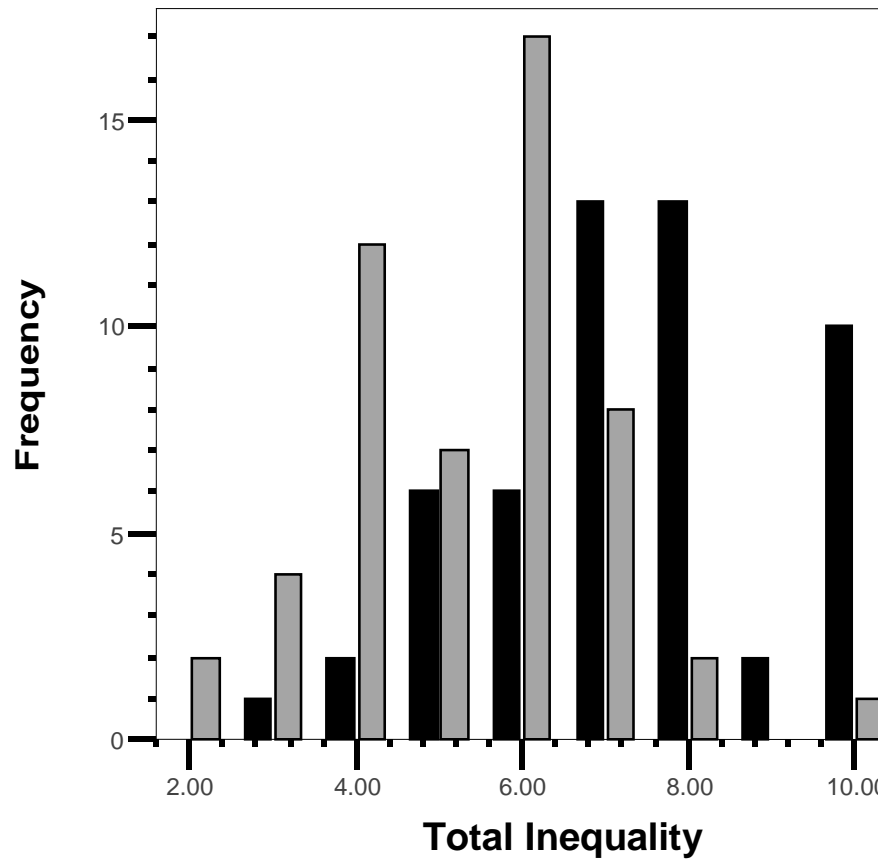

Germany

The Netherlands

Bars show counts

Figure 6. 10 Total Inequality Attitudes

This pattern might be explained by Milli Gorus's perception of the host society. While German Milli Gorus perceives German society as a threat to its existence, Dutch Milli Gorus perceives Dutch society as a field of opportunities. German Milli Gorus's perception of German society results in promotion of an immigrant community where women have limited or no contact with the outside world. Dutch Milli Gorus's perception of Dutch society, on the other hand, encourages women to take active roles in Dutch society which is reflected in the fact that Women's Federation of Milli Gorus in the Netherlands is one of the most active departments within Milli Gorus. The federation not only plays an active role within the movement but also in Dutch political and social life.

Question A54 was designed to understand the level of puritanism among Milli Gorus members. The respondents were asked if they agreed, strongly agreed, disagreed or strongly disagreed with the statement that while interpreting Qur'an, one should take 
today's circumstances into consideration. As figure 6.10 indicates, the biggest group in Germany disagreed or strongly disagreed with the statement while the biggest group in the Netherlands agreed or strongly agreed with it. Therefore, we can conclude that Milli Gorus in Germany is more puritanical than Milli Gorus in the Netherlands.

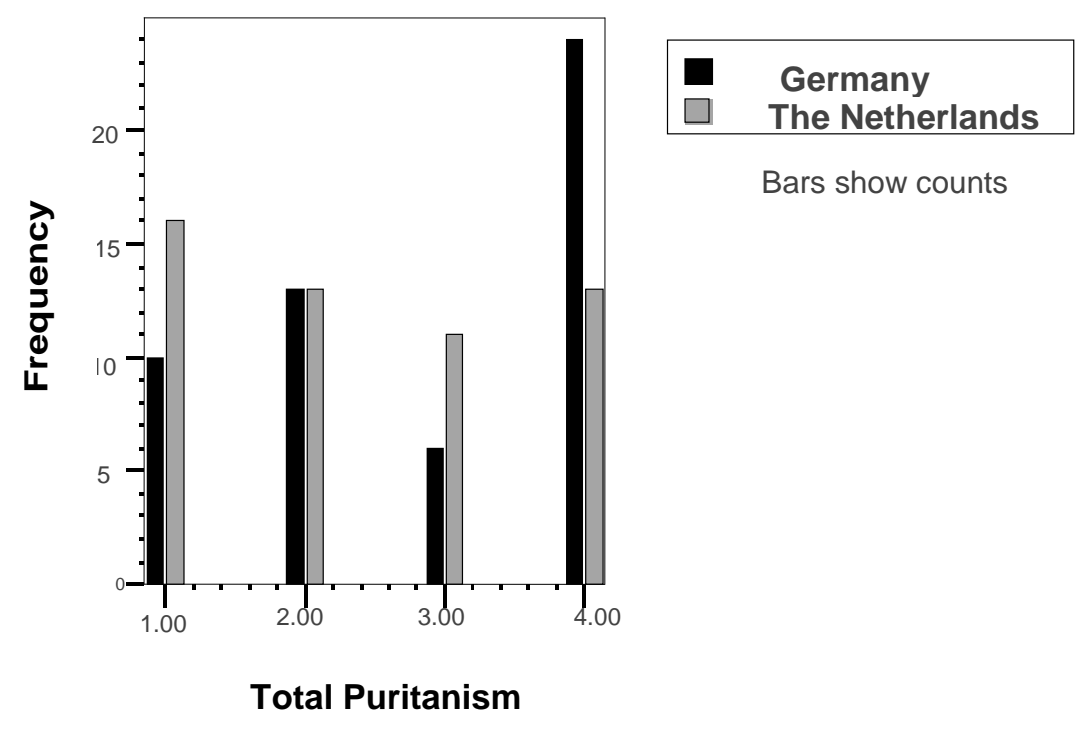

Figure 6. 11 Total Puritanism

The attitudes towards having a monoethnic community instead of a multiethnic/multi-religious one is measured by question A55. Respondents were asked what type of society they would like to live in: multi-religious or Islamic society. As Figure 6.11 indicates a bigger majority of the German Milli Gorus members prefer to live in an isolated Islamic society than the Dutch Milli Gorus members.

The level of anti-integrationism was measured by asking question A56. Respondents were asked to pick the best environment to raise their children: a religiously mixed neighborhood or a Turkish neighborhood. As shown by Figure 6.12, German Milli Gorus members demonstrate higher anti-integrationist tendencies. They are more prone 
to living in isolated communities while the majority of their Dutch counterpart prefers to live in religiously and ethnically mixed communities.

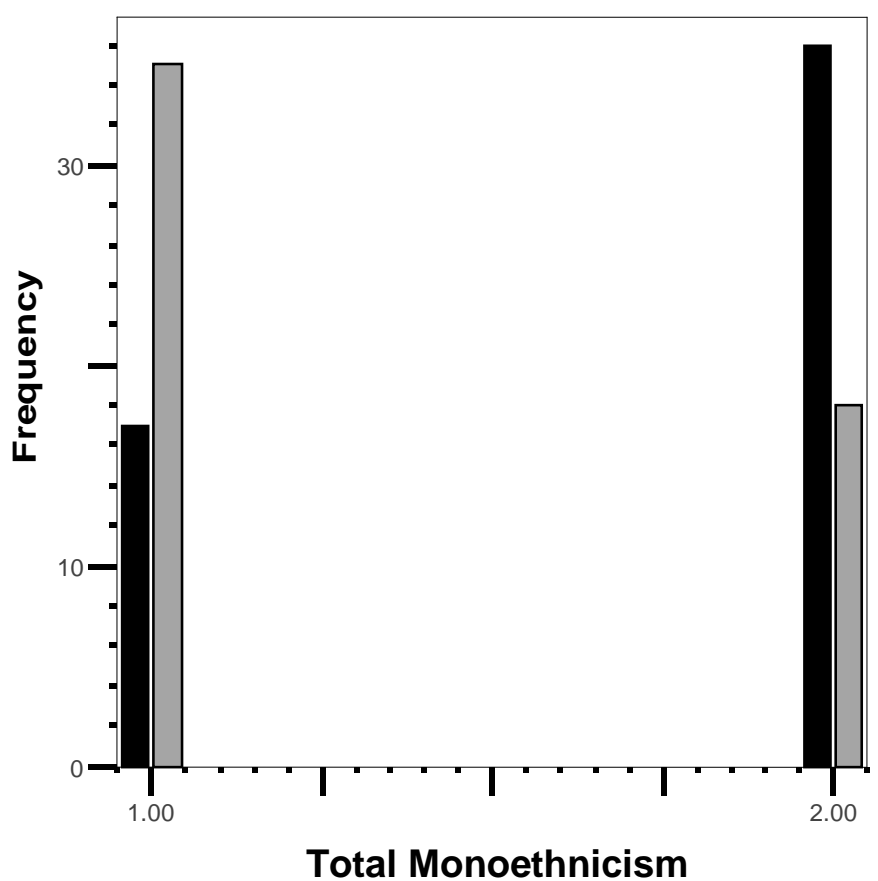

Germany

The Netherlands

Bars show counts

Figure 6.12 Total Monoethnicism Attitudes

Total anti-integrationism, total monoethnicism, total non-secularism, total antidemocracy, total anti-Westernism, total inequality and total anti-tolerance are different indicators of radicalism. Germany's higher scores on each of these variables are indicators of higher radicalism among Milli Gorus members in Germany than Milli Gorus in the Netherlands. A t-test is conducted in order to assess whether the average level of radicalization relative to each of the eight radicalization dimensions I created is significantly different in Germany and the Netherlands.

Table 6.4 summarizes the findings of the t-test. For all dimensions except total anti-Westernism, puritanism and non-secularism, Germany shows significantly higher 
radicalization than the Netherlands at .1 significance level. The reason for the higher $p$ value for anti-Westernism was explained in the previous section.

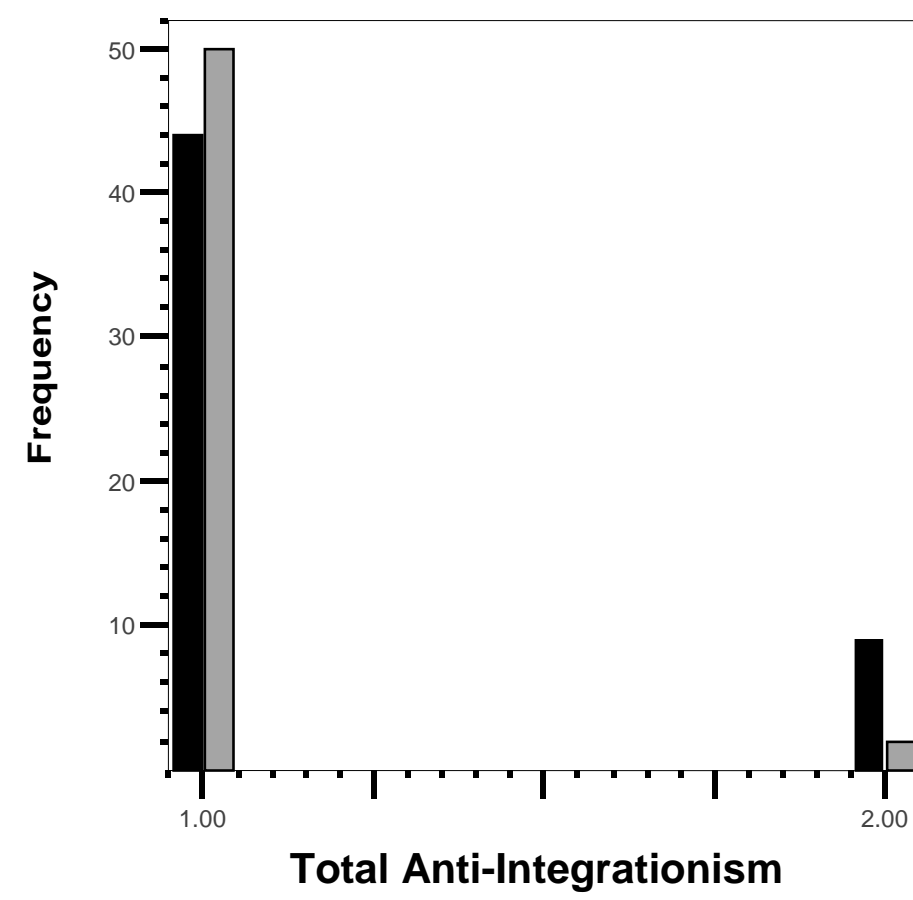

Germany

The Netherlands

Bars show counts

Figure 6.13 Total Anti-integrationist Attitudes

\subsection{TOTAL MARGINALIZATION AND TOTAL RADICALIZATION}

Finally, two variables are created: Total Marginalization and Total Radicalization by summing all the marginalization and radicalization variables. Educational marginalization was excluded from the analysis since there were too many missing variables. After creating Total Marginalization and Total Radicalization, the two cases are compared using t-test. The correlation between marginalization and radicalization is measured using a regression model.

Total Marginalization index was created by summing all the marginalization variables: total social marginalization, total cultural marginalization, total economic 
marginalization and total political marginalization which consist of questions from A5 to A26. Figure 6.13 clearly indicates that the modal category in Germany is more to the right which shows that the biggest group in Germany is more marginalized than the biggest group in the Netherlands. This indicates that Germany's level of total marginalization is higher than that of the Netherlands.

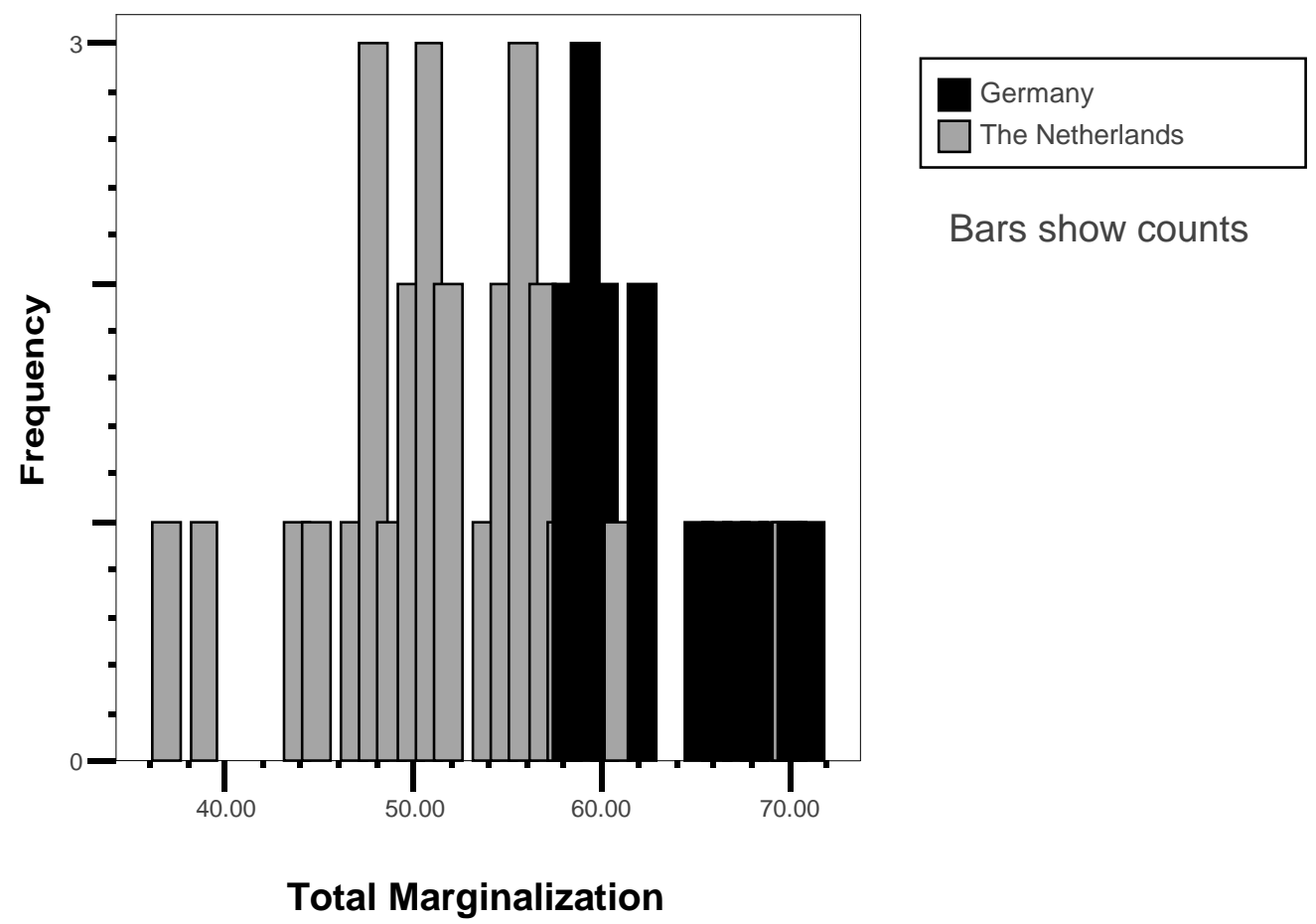

Figure 6. 14 Total Marginalization Indicators

Total radicalization index was created by summing all the radicalization variables: total anti-tolerance, total inequality, total anti-westernism, total anti-democracy, total nonsecularism, total puritanism, total monoethnicism, total anti-integrationism which consist of questions from A27 to A56. Figure 6.14 shows that Germany's overall level of total radicalization is higher than total radicalization of the Netherlands. Analysis of the 
Table 6. 4 Independent Samples Test of Radicalization

\begin{tabular}{|c|c|c|c|c|c|c|c|c|c|c|}
\hline & & \multicolumn{2}{|c|}{$\begin{array}{l}\text { Levene's Test } \\
\text { for Equality of } \\
\text { Variances }\end{array}$} & \multicolumn{7}{|c|}{ t-test for Equality of Means } \\
\hline & & \multirow[t]{2}{*}{$\mathrm{F}$} & \multirow[t]{2}{*}{ Sig. } & \multirow[t]{2}{*}{$\mathrm{t}$} & \multirow[t]{2}{*}{ df } & \multirow[t]{2}{*}{$\begin{array}{l}\text { Sig. } \\
(2- \\
\text { tailed) }\end{array}$} & \multirow[t]{2}{*}{$\begin{array}{l}\text { Mean } \\
\text { Difference }\end{array}$} & \multirow[t]{2}{*}{$\begin{array}{l}\text { Std. Error } \\
\text { Difference }\end{array}$} & \multicolumn{2}{|c|}{$\begin{array}{l}\% 95 \text { Confidence } \\
\text { Interval of the } \\
\text { Difference }\end{array}$} \\
\hline & & & & & & & & & Lower & Upper \\
\hline \multirow{2}{*}{$\begin{array}{l}\text { Total } \\
\text { Puritanism }\end{array}$} & Equal Variances Assumed & .40 & .528 & 1.88 & 104 & .062 & .43 & .23 & -.02 & .89 \\
\hline & Equal Variances Not Assumed & & & 1.88 & 103.88 & .062 & .43 & .23 & -.02 & .89 \\
\hline \multirow{2}{*}{$\begin{array}{l}\text { Total } \\
\text { Monoethnicisim }\end{array}$} & Equal Variances Assumed & .16 & .683 & 3.68 & 104 & .000 & .33 & .09 & .15 & .52 \\
\hline & Equal Variances Not Assumed & & & 3.68 & 103.97 & .000 & .33 & .09 & .15 & .52 \\
\hline \multirow{2}{*}{$\begin{array}{l}\text { Total } \\
\text { Anti- } \\
\text { Integrationism }\end{array}$} & Equal Variances Assumed & 23.88 & .000 & 2.22 & 103 & .028 & .13 & .058 & .014 & .24 \\
\hline & Equal Variances Not Assumed & & & 2.24 & 77.85 & .028 & .13 & .058 & .014 & .24 \\
\hline \multirow{2}{*}{$\begin{array}{l}\text { Total } \\
\text { Anti -Tolerance }\end{array}$} & Equal Variances Assumed & 24.13 & .000 & 6.50 & 100 & .000 & 3.12 & .48 & 2.17 & 4.08 \\
\hline & Equal Variances Not Assumed & & & 6.40 & 83.04 & .000 & 3.12 & .48 & 2.15 & 4.09 \\
\hline \multirow{2}{*}{$\begin{array}{l}\text { Total } \\
\text { Inequality }\end{array}$} & Equal Variances Assumed & .48 & .486 & 6.11 & 104 & .000 & 2.01 & .32 & 1.36 & 2.67 \\
\hline & Equal Variances Not Assumed & & & 6.11 & 102.5 & .000 & 2.01 & .32 & 1.36 & 2.67 \\
\hline \multirow{2}{*}{$\begin{array}{l}\text { Total } \\
\text { Anti-West }\end{array}$} & Equal Variances Assumed & 18.50 & .000 & 1.16 & 103 & .247 & .22 & .19 & -.15 & 0.60 \\
\hline & Equal Variances Not Assumed & & & 1.17 & 84.61 & .245 & .22 & .19 & -.15 & 0.60 \\
\hline \multirow{2}{*}{$\begin{array}{l}\text { Total } \\
\text { Anti-Democracy }\end{array}$} & Equal Variances Assumed & .004 & .949 & 6.33 & 94 & .000 & 4.09 & .64 & 2.81 & 5.37 \\
\hline & Equal Variances Not Assumed & & & 6.38 & 93.99 & .000 & 4.09 & .64 & 2.82 & 5.36 \\
\hline \multirow{2}{*}{$\begin{array}{l}\text { Total } \\
\text { Non-Secular }\end{array}$} & Equal Variances Assumed & .020 & .888 & 1.79 & 98 & .076 & .84 & .47 & -.09 & 1.77 \\
\hline & Equal Variances Not Assumed & & & 1.79 & 97.04 & .076 & .84 & .47 & -.08 & 1.77 \\
\hline
\end{tabular}


survey data shows that German Milli Gorus is more marginalized and radicalized than Dutch Milli Gorus. In order to assess the relationship between the two variables, simple regression analysis is conducted.

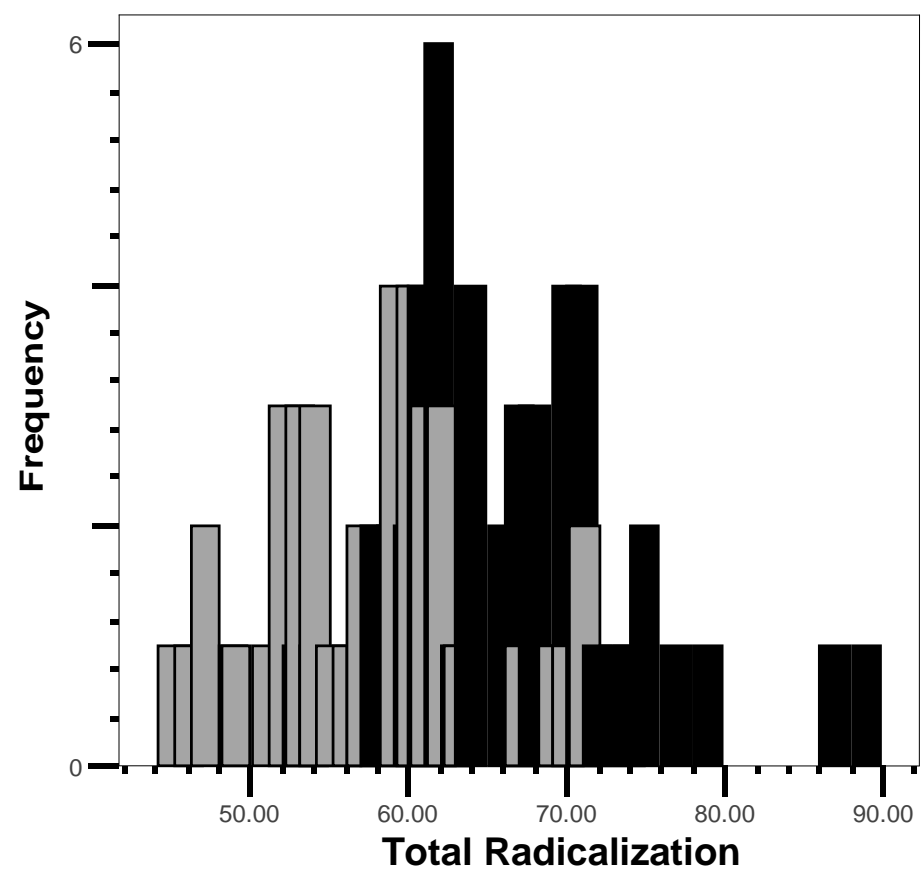

Germany

The Netherlands

Bars show counts

Figure 6. 15 Total Radicalization Indicators

\subsection{CORRELATION BETWEEN TOTAL MARGINALIZATION AND TOTAL}

\section{RADICALIZATION}

Looking at Figure 6.15 it can be seen that total marginalization and total radicalization are positively correlated. As the level of total marginalization increases, so does the level of total radicalization.

To test the independent impact of marginalization on radicalization, I conducted multivariate linear regression analysis. The dependent variable is total radicalization, 
which is measured by summing all the radicalization indicators used in the preceding descriptive analysis.

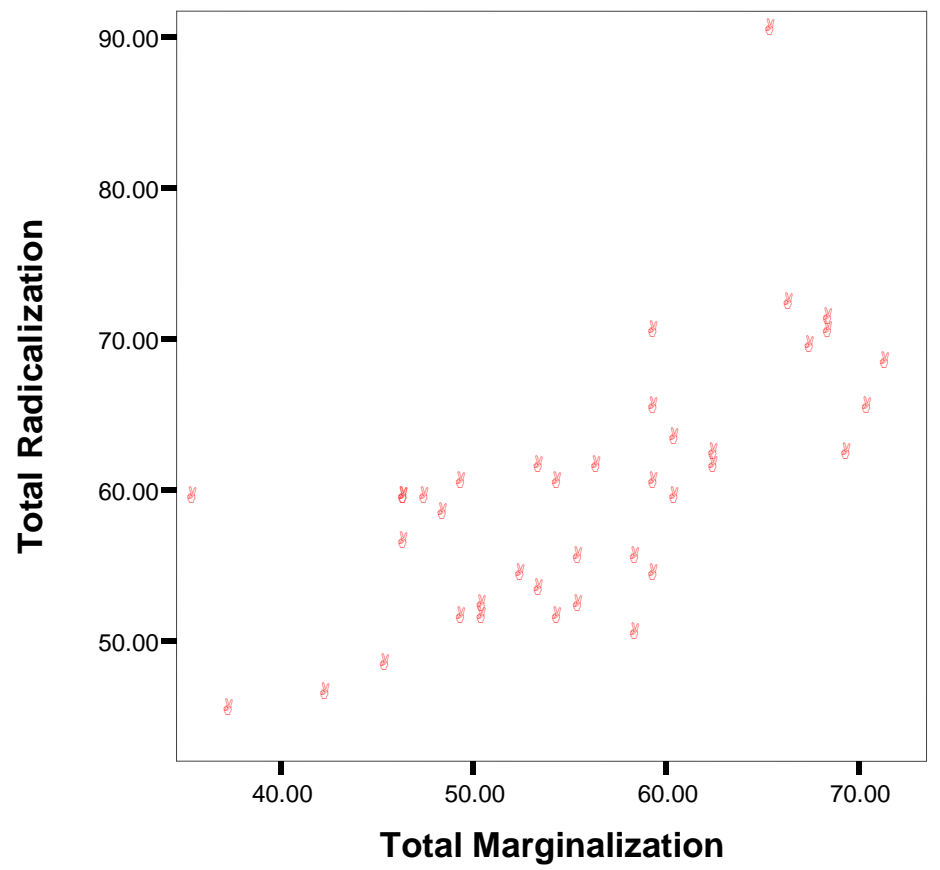

Figure 6. 16 Correlation between Total Radicalization and Total Marginalization

Similarly, the central independent variable, marginalization, is the sum of all but two indicators, economic marginalization and educational marginalization which were eliminated due to too many missing values. In order to control for other possible determinants of radicalization, control variables for age and gender were incorporated into the regression model.

The regression results reported in Table 6.5 indicate that neither age nor gender has a statistically significant impact on radicalization. Even after controlling for two demographic factors, the impact of marginalization on radicalization remains significant at the .001 level, with a magnitude of .57 . Therefore, I can conclude that the data from 
Germany and the Netherlands offer solid support for the hypothesis that radicalization is a function of marginalization.

Table 6. 5 Regression Results

\begin{tabular}{|l|l|l|l|l|}
\hline Independent & $\mathrm{B}$ & Std. Error & $\mathrm{t}$ & Sig. \\
Variable & & & & \\
\hline Marginalization & $.57^{*}$ & .09 & 6.11 & .00 \\
& .51 & 1.99 & .26 & .79 \\
Gender & -.19 & .99 & -.20 & .84 \\
Age & $24.71^{*}$ & 6.67 & 3.70 & .00 \\
Intercept & & & & \\
\hline Adj. $R^{2}$ & .41 & \multicolumn{5}{|l}{} \\
$\mathrm{N}$ & 52 & & \\
\hline
\end{tabular}

$* \mathrm{p}<.00$ 


\section{CHAPTER 7}

\section{CONCLUSION}

The Islamic challenge that Europe faces today is twofold. Internally, Europe must integrate an increasingly alienated and growing Muslim minority that many Europeans view as "encroaching upon the collective identity and public values of European society" (Savage 2004). Externally, Europe needs to adopt a viable approach to the Muslim populated states, stretching from Morocco to the Caucasus. The Muslim factor is adding new complexities to Europe's domestic and foreign policies in more than just demographic and geographical terms. Today Europe faces a variety of different challenges including the rise of radical Islamism; the emergence of anti-Semitism; the shift of established European political parties to the right; additional problems for achieving a closer European Union and reformulation of European foreign policy (Savage 2004).

Europe's reencounter with Islam requires a different approach since it is operating under different conditions with different internal dynamics. This study focuses on these conditions and dynamics and argues that Islamism is not a project that has an enduring, ahistorical essence. It is a response given to the challenges of modernity and therefore it should be understood within the context in which it operates. It is not a static phenomenon. Its discourse and ideology and the role it plays within the Muslim community reflect the societal dynamics. Islamist movements might generate a counterhegemonic discourse and become an opposition strategy or they might be a potential force for democratization of the Muslim community. They are capable of political 
learning and generating democratic civil society activism given the opportunity to become a legitimate actor in the democratic and societal processes.

The findings of this study have important policy implications especially for West European states which have sizable Muslim immigrant populations. The increasingly permanent Muslim presence in Western European public space is raising deeper questions and challenges to both sides not only in terms of demography and economy but also in terms of issues related to individual and collective senses of identity. The findings of this study suggest that European states ultimately control institutionalization of Islam in Europe. Their laws, rules and regulations not only determine who gets what but also who is what. They define the place of Islam and Muslims within the European public space; they shape the perceptions of the Muslim community and the host society; they regulate the relationship between the two; they set the boundaries of belonging, letting some in, leaving some out. Recognizing the pivotal role host country policies play on the type of role Islamism assumes, the next section provides policy recommendations to states which are facing the social, economic and political challenges of accommodating their Muslim immigrant communities.

\subsection{POLICY RECOMMENDATIONS}

Social marginalization leads to radicalization. In order to control the processes of radicalization, governments have to prevent social marginalization. Social marginalization is composed of three elements: economic marginalization, social marginalization and political marginalization. In this section, policy goals are formulated based on the economic, political and social components of marginalization. These various 
policy goals are grouped under three headings: increasing social confidence, increasing political confidence and increasing upward economic mobility.

\section{1) Increasing Social Confidence}

Goal 1: Reduce Social Isolation

A lack of social relations with the host society influences the process of radicalization. Fewer contacts with the surrounding environment lead to a social and cognitive gap between the immigrant community and the host society. Such a gap creates an environment where there is no communication and personal contact between the two groups and thus no real understanding of the other. Under these circumstances, the other is formulated based on prejudices and the sense of fear stemming from lack of knowledge of the other. This social gap results in establishing a closed community among the immigrants. They look for a place where they are accepted and valued; they can find this in an Islamist community. The sense of being socially excluded from the host society leads to a more orthodox interpretation of Islam which provides a strong positive identity. The more they are socially isolated, the more they are engaged in their own community, and thus the less tolerant they become towards diversity and multi-culturalism.

\section{Suggestions:}

- Prevent establishment of ethnic/religious enclaves by providing upward economic mobility among the immigrants. The majority of the Milli Gorus members in Germany told that they lived in Turkish neighborhoods because of economic and psychological necessity. They mentioned that they had nowhere else to in a society which does not want them. 
- Provide free language courses for immigrant families where they can learn the language of the host society, which might also increase their chances in the labor market.

- Establish programs that bring native population and the immigrant community together at the local level, especially programs for women and youth, which can provide an opportunity to establish personal contacts between the two groups.

Goal 2: Reduce the Feeling of Discrimination

The feeling of being discriminated against is a factor that enhances the view that society is governed by illegitimate institutions that are oppressing those who do not share the ethnic, religious or cultural background of the host society. Addressing this feeling is essential to the prevention of radicalization. Discrimination causes psychological insecurity, which may damage an individual's or a group's contact with society. When groups or individuals do not feel accepted, they develop a sense of victimization and they may withdraw into an environment which they know well and value them. They look for security in that environment and become intolerant of diversity. They may become rigid and defensive (Slootman \& Tillie 2006: 106).

Suggestions:

- Do not demand a single loyalty, accept and institutionalize the understanding that individuals and groups have multiple identities and these different identities can coexist without conflicting with each other. A continuous effort to suppress the religious or ethnic identities of immigrants creates a reaction and a feeling of oppression. 
- Offer a positive social identity. The possibility of maintaining an "old" identity can strengthen identification with the host country (Meertens 2005 in Slootman \& Tillie 2006: 106).

- Address feelings of victimization by expressing the contributions of the immigrant culture/religion to the culture of the host society. Let success stories among the immigrant group be heard.

- Build a positive atmosphere in society by refraining from accusations of the immigrant community for economic, social and political problems. Do not use an ethnically/religiously divided language while confronting social problems. Such language may create resentment on both sides.

Goal 3: Deemphasize Islam and Muslims as a Source of Tension

The feeling that Islam forms a point of conflict in society is an important reason for radicalization. The main tenet of the radical Islamist ideology is that Islam is under attack and must be defended (Slootman \& Tillie 2006:105). Almost all Milli Gorus members in Germany expressed serious concerns for the treatment of Islam and Muslims in the West. They stated that the tone of discussion about Islam was very negative and Muslims should unite in order to defend their religion.

Suggestions:

- Create open discussion about Islam. This would increase the level of knowledge about Islam and provide an understanding of the diversity within Islam.

- Make sure positive aspects of Islam are emphasized.

- Use a constructive language about the role of religion, of Islam in particular, in individual's life. 
- Refrain from making generalizations about Islam. Do not speak of the Islam or the Muslims and do not present Islam as the source of all problems.

2) Increasing Political Confidence

Goal 1: Provide Political Integration

Political integration means being part of the democratic political process. Citizenship is the most important factor that provides such integration. It means membership in a community; it is not just a physical belonging but a political one. The right to citizenship implies the right to vote and thus participation in the decision-making process. Such participation not only makes the system legitimate in the eyes of the Muslim immigrant community but also provide them legitimate ways of expressing their frustrations and concerns. Milli Gorus members in Germany lack citizenship rights and thus legitimate means to express themselves. They turn to Islamism to express their fears, concerns and frustrations. A radical ideology becomes the only means available to survive in a system that denies them the right to be part of it.

Suggestions:

- Make the naturalization process easier. An easier naturalization means higher naturalization rates. As more immigrants become citizens, the system is considered legitimate by more people. Granting citizenship means pulling people inside the system and provides them tools to work their problems within democratic principles.

- Grant right to dual nationality. The most important reason for the low naturalization figures in Germany is the lackof dual nationality for adults. Almost all Milli Gorus members who were not German citizens stated that they had not 
become citizens because they did not want to give up their Turkish nationality. Giving up Turkish nationality means giving up inheritance rights and the right to buy property in Turkey. It is a practical and psychological necessity for them. Granting the right to dual nationality can increase the naturalization figures.

- Establish official channels of communication between Islamic organizations and local authorities. This would provide the Muslim community a legitimate way of expressing their concerns and create a feeling of recognition by the host society institutions which would increase the legitimacy of the system in the eyes of the Muslim community.

- Take Islamic organizations seriously as equal partners in dialogue.

3) Increasing Upward Economic Mobility

Goal 1: Provide Equal Opportunities

Economic opportunity plays an important role in the integration process of Muslim immigrants. Economic success and its accompanying upward mobility can provide incentives for integration. Restricted economic opportunity may induce immigrant groups to use economic adaptive strategies, such as the formation of ethnic/religious niches, which may deter integration (Barth, 1969). If there is limited access to economic opportunity, Muslim immigrant group members may resort to the formation of closed ethnic/religious associations and neighborhoods for protection and thus isolate themselves even more from the larger society (Wong, 1974). As indicated earlier, groups that are socially, economically and politically isolated are more likely to turn to radical ideologies than groups that are integrated into the wider environment. 


\section{Suggestions:}

- Pass and enforce anti-discrimination laws for the job market.

- Guarantee equal opportunities for work, internships and education. Compensate for disadvantages as early as possible (pre-school education, language lessons for non-native speaker) (Slootman \& Tillie 2006: 106).

Goal 2: Fight the Disadvantaged Labor Market Position of the Muslim Immigrants According to the statistics conducted by EUROSTAT for Western Europe, migrants of both first and second generation persistently score worse than nationals in terms of average unemployment rates (Bohning \& Beijl 1995). The contributing factors to the relative labor market disadvantage of Turks compared to indigenous workers are their over-representation in the more vulnerable unskilled occupations especially in manufacturing and the host society's knowing or unknowing discrimination against nonnationals.

Suggestions:

- Offer training and vocational practice to unemployed youngsters.

- Run subsidized vocational training and apprenticeship schemes in favour of unemployed young Muslims. Increase public subsidies if ethnic/religious minority members enter the scheme.

- Offer vocational education at the secondary and higher level through vocational colleges.

- Allow Islamic organizations establish Islamic schools. Such schools are proven to be quite successful in the Netherlands since they offer high-quality education and a positive environment to Muslim students where their beliefs are shared by the 
surrounding environment. These schools can help create a middle class among the Muslim community which can be force for democratization of the immigrant community.

\subsection{CONTRIBUTIONS TO THE LITERATURE}

This study makes two important contributions to the existing literature on Islamism. First, it provides an alternative theoretical framework which does not take Islam's role in Islamist discourse for granted and assigns a changing role to Islam within Islamist rhetoric. It takes a position in between the orientalist and the anti-orientalist approach by arguing that the relationship between Islam and Islamism is a constructive relationship where both Islam and Islamism are transformed. The alternative theoretical perspective that is provided by this study urges us to look at the systemic factors in order to understand the dynamics of this relationship. By treating Islam and Islamism as constantly changing phenomena in response to the dynamics that surround them, this approach brings a dynamic approach to the study of Islamism in which essentialized images of Islam are not taken as explanatory factors.

Second, it utilizes methodological tools that are not used often in the Islamism literature due to the delicate nature of the topic such as survey technique and participant observation. Treating Islamism as both a social and religious phenomenon requires a new methodological approach. Treating Islamism as a religious phenomenon would require understanding the holy texts and the meanings they generate but would tell us little about the interaction between those meanings and the social environment. Treating it solely as a social phenomenon would be equally deceptive since it would strip Islam off any positive meaning. Treating Islamism as a social and religious phenomenon, on the other hand, 
emphasizes the relationship between Islam and the social, political and economic context in which it operates. Such approach requires looking at what Islam means for Muslims and how that meaning is shaped in relation to the social environment. Despite the challenges, the survey technique and participant observation become very important tools in understanding those meanings. A survey that is designed to reveal the perceptions of the Islamist group and intense participant observation in which both the Islamist group and the host society are examined provide the researcher valuable insight into the phenomenon, which she/he cannot acquire with any other technique.

Utilizing the survey technique and participant observation, this study has provided a new theoretical approach and responded to a need in the literature for an empirically sound and theoretically grounded study on Islamist movements. It opened a window into life in Europe among Turkish immigrants and provided human faces to a phenomenon which has long been understood in a unidimensional and monolithic way by the nonMuslim world. 


\section{LIST OF REFERENCES}

Appleby, Scott.1994. Religious Fundamentalisms And Global Conflict. New York, NY: Foreign Policy Association.

Ajami, Fouad. 1981. The Arab Predicament. Cambridge: Cambridge University Press.

AIVD Report. 2004. From Dawa to Jihad: The Various Threats from Radical Islam to the Democratic Legal Order, report published by the Dutch Ministry of the Interior, December, http://www.aivd.nl/contents/pages/42345/fromdawatojihad.pdf.

Annual Report 2005 on the Protection of the Constitution. 2005. Report prepared by the German Federal Ministry of the Interior.

Barth, Fredrik. 1969. Ethnic Groups and Boundaries. London: George Allen and Unwin.

Backstrom, Charles H., Gerald Hursh-Cesar. 1981. Survey Research. $2^{\text {nd }}$ ed. New York: Macmillan.

Bayar, A.H. 1996. "Development of Ethnic Business in Europe: The Case of Turkish Immigrants," Paper presented at the international conference Labour Markets and Human Resource Development, 16-18 September, Kuwait.

Beach, Walter G. 1934. "Some Considerations in Regard to Race Segregation in California" Sociology and Social research, 18 (March), 340-50.

Befu, Harumi. 1965. "Contrastive Acculturation of California Japanese," Human Organization, 24, 209-16.

Bell, Daniel. 1975. "Ethnicity and Social Change," in N. Glazer and D. P. Moynihan eds. Ethnicity: Theory and Experience. Cambridge; Massachusetts; London; England: Harvard University Press.

Bernard, Russell H. 1995. Research Methods in Anthropology. Thousand Oaks, CA: Sage Publications.

Billings, Dwight B. 1990. "Religion as Opposition: A Gramscian Analysis." The American Journal of Sociology, 96 (1), July, 1-31.

Bocker, Anita. 2004. "The Impact of Host-Society Institutions on the Integration of Turkish Immigrants in Germany and the Netherlands," Paper presented at the workshop on integration of immigrants from Turkey in Austria, Germany and the Netherlands, Bogazici University, Istanbul, February 27-28, 2004. 
Bohning, W.R. and R. Zegers de Beij1. 1995. "The Integration of Migrant Workers in the Labor Market: Policies and Their Impact." International Migration Papers 8. Geneva: International Labor Office.

Boucher, Geoff. 2000. "Hegel and Postmodern Discourse Theory," Hegel-Marx-Derrida Seminar, Melbourne 18 February, http://www.ethicalpolitics.org/geoffboucher/2000/postmodernism.htm.

Broom, Leonard and John Kitsuse. 1955. "The Validation of Acculturation: A Condition of Ethnic Assimilation," American Anthropologist, LVII (48), 44-48.

Brubaker, R. 1992. Citizenship and Nationhood in France and Germany. Harvard.

Bruinessen, Martin van. 2004. "Milli Gorus in Western Europe" presentation given at the ISIM workshop, Leiden, 9 January.

Cavatorta, Francesco. 2006. "Civil Society, Islamism and Democratisation: The Case of Morocco", Journal of Modern African Studies, 44 (2), 203-222.

Cahoonee, Lawrence. 1996. From Modernism to Postmodernism: An Anthology. Cambridge, Mass: Blackwell.

CBS Report. 2007. "Population, Age and Nationality", http://www.cbs.nl/enGB/menu/themas/dossiers/allochtonen/nieuws/default.htm, 04/27/2007.

Chantepie de la Saussaye, P.D. 1891. Manual of the Science of Religion. London: Longmans, Green and Co.

Crissman, Lawrence. 1967. "The Segmentary Structure of Urban Overseas Chinese Communities," Man, 2: 185-204.

Dagevos, J., R. Euwals, M. Gijsberts, H. Roodenburg. 2007. "The Labor Market Position of Turkish Immigrants in Germany and the Netherlands: Reason for Migration, Naturalization and Language Proficiency," IZA Discussion Papers 2683, Institute for the Study of Labor.

Davidson, Lawrence. 2003. Islamic Fundamentalism: An Introduction. Westport, Connecticut: Greenwood Press.

DITIB-Germany official website. www.ditib.de.

DITIB-the Netherlands official website. www.diyanet.nl.

Dominguez, Jorge and James A. McCann. 1996. Democratizing Mexico: Public Opinion and Electoral Choices. Baltimore: The Johns Hopkins University Press. 
Doomernik, Jeroen. 1995. "The Institutionalization of Turkish Islam in Germany and the Netherlands: A Comparison" in Ethnic and Racial Studies, vol. 18, no.1, January.

Dronkers, Japp. 1993. "Is the Importance of Family Decreasing? Evidence Regarding Dutch Sibling Data and Educational Attainment." In W. Meeus, M. de Goede, W. Kox, K. Hurrelmann, eds. Adolescence, Careers and Cultures. Berlin: Walter de Gruyter.

Durkheim, Emile. 1965. Elementary Forms of the Religious Life. New York: Free Press.

El-Zien, Abdul Hamid. 1977. "Beyond Ideology and Theology: The Search for Anthropology of Islam”, Annual Review of Anthropology, VI, 227-254.

Eliade, Mircea. 1958. Birth and Rebirth. New York: Harper.

Entzinger, H. 2003. "The Rise and Fall of Multiculturalism: The Case of the Netherlands," in C. Joppke and E. Morawaska, eds. Toward Assimilation and Citizenship: Immigrants in Liberal Nation-States. Basingstoke: Palgrave Macmillan.

Esposito, John L. 1991. Islam and Politics. $3^{\text {rd }}$ ed. Syracuse: Syracuse University Press.

Esposito, John L. 1992. The Islamic Threat: Myth or Reality. New York and Oxford: Oxford University Press.

Fellows, Donald K. 1972. A Mosaic of America's Ethnic Minorities. New York:John Wiley.

Fennema, Meindert, Jean Tillie. 2000. "Ethnic Associations, Political Trust and Political Participation" in Multicultural Policies and Modes of Citizenship in European Cities Project, Instituut voor Migratie-en Etnische Studies.

Fennema, Meindert, Jean Tillie, Karen Kraal. 2000. "Creating Networks within the Turkish Community" in Multicultural Policies and Modes of Citizenship in European Cities Project, Instituut voor Migratie-en Etnische Studies.

Fiorenza, Francis Schussler. 2000. "Religion: A Contested Site in Theology and the Study of Religion," The Harvard Theological Review, 93 (1), January, 7-34.

Fischer, Michael M. J. 1982. "Islam and the Revolt of the Petit Bourgeoisie", Daedalus, 3 (1), Winter.

Fox, Jonathan. 1999. "The Influence of Religious Legitimacy on Grievance Formation by Ethnoreligious Minorities.” Journal of Peace Research, 36 (3), May, 289-307.

Geddes, Andrew. 2003. The Politics of Migration and Immigration in Europe. London; New Delhi: Sage Publications. 
Gerholm T. and Lithman, Y.G. 1988. The New Islamic Presence in Western Europe. London: Mansell Publications.

Gilsenan, Michael. 1990. Recognizing Islam. London: I.B. Tauris.

Glazer, Nathan, Daniel P. Moynihan. 1975. "Introduction" in Nathan Glazer and Daniel P. Moynihan, eds. Ethnicity: Theory and Experience. London, England: Harvard University Press.

Gordon, Milton. 1964. Assimilation in American Life. New York: Oxford University Press.

Gramsci, Antonio. 1971. Selection from the Prison Notebooks. New York: International.

Groenendijk, C.A. and E.J.M. Heijs. 2001. "Immigration, Migrants and Naturalization in the Netherlands 1945-1997," in R. Hansen and P. Weil, eds. Towards a European Nationality, Citizenship and Immigration and Nationality Law in the EU. London: Palgrave.

Guitta, Olivier. 2006. "The State Department Was Right to Deny Tariq Ramadan a Visa" Weekly Standard, 10/16/2006, 12 (5).

Gurr, Ted Robert. 1993. Minorities at Risk: A Global View of Ethnopolitical Conflicts. Washington DC: United States Institute of Peace Press.

Habermas, Juergen. 1994. "Struggles for Recognition in the Democratic Constitutional State." In Amy Gutman, eds. Multiculturalism: Examining the Politics of Recognition. Princeton, NJ: Princeton University Press.

Halliday, Fred. 1987. "The Iranian Revolution and Its Implications." New Left Review 166 (Nov/Dec): 29-37.

Halliday, Fred. 1995. "Fundamentalism and the Contemporary World." Contention:Debates in Society, Culture, and Science 4(2)

Halliday, Fred. 1996. Islam and the Myth of Confrontation:Religion and Politics in the Middle East. London. I.B. Tauris Publishers.

Hanafi, Hasan. 1985. "The Origin of Modern Conservatism and Islamic Fundamentalism.” In Ernest Gellner, eds. Islamic Dilemmas. Berlin, New York and Amsterdam: Mouton Publishers.

Heckmann, F. 2003. "From Ethnic Nation to Universalistic Immigrant Integration: Germany" in F. Heckman, D. Schnapper eds. The Integration of Immigrants in European 
Societies: National Differences and Trends of Convergence. Stuttgart: Lucius and Lucius, 2003.

Hegel, G.W.F. 1977. Phenomenology of Spirit. Oxford University Press.

Horowitz, Donald L. 1985. Ethnic Groups in Conflict. CA: University of California Press.

Isaacs, Harold R. 1975. "Basic Group Identity: The Idols of the Tribe.” In Nathan Glazer and Daniel P. Moynihan, eds. Ethnicity: Theory and Experience. Cambridge, Massachusetts, and London, England: Harvard University Press.

Johnson, Benton. 1961. "Do Holiness Sects Socialize in Dominant Values?" Social Forces, 39, 309-316.

Johnson, A., R. Sackett. 1998. "Direct Systematic Observation of Behavior," in R. Bernard eds. Handbook of Methods in Cultural Anthropology. Walnut Creek, CA: Altamira Press.

Kaemzadeh, Masoud. 1996. "The State, Civil Society and the Prospects of Islamic Fundamentalism." Comparative Studies of South Asia, Africa and the Middle East 16(1).

Keddie, Nikki. 1983. An Islamic Response to Imperialism. Berkeley: University of California Press.

Kepnes, Steven D. 1986. Bridging the Gap between Understanding and Explanation Approaches to the Study of Religion," Journal for the Scientific Study of Religion, 25 (4), December, 504-512.

Kinzer, Stephen. 1993. "Turks in Berlin Call 1-Hour Strike to Urge Action on Arson Attacks", New York Times, June 10.

Knowles, Petia Dimitrova. 2002. "Gender across Cultures: The Immigration Experience/Bulgarian Immigrants in South Florida," unpublished Ph.D. Dissertation.

Kolat, Kenan.2004. "An Approach towards Non-Governmental Organizations and Pressure Groups", Paper presented at the workshop on integration of immigrants from Turkey in Austria, Germany and the Netherlands, Bogazici University, Istanbul, February 27-28, 2004.

Koopmans, Ruud. 1999. "Germany and Its Immigrants: An Ambivalent Relationship," Journal of Ethnic and Migration Studies, October, vol. 25, no.4. 
Kösebalaban, Hasan. 2003. 'The Making of Enemy \& Friend: Fethullah Gülen's National-Security Identity' in M. Hakan Yavuz, \& John, L. Esposito, eds. Turkish Islam and the Secular State: The Gülen Movement. New York: Syracuse University Press.

Lacan, Jaques. 1977. Four Fundamentals of Psychoanalysis. Harmondsworth, UK: Penguin.

Laclau, Ernesto and Chantal Mouffe. 1985. Hegemony and Socialist Strategy: Toward a Radical Democratic Politics. London: Verso.

Layton-Henry, Zig. 1990. The Political Rights of Migrant Workers in Western Europe. London; Newbury Park; New Delhi: Sage Publications.

Lee, Rose. 1960. The Chinese in the United States of America. Hong Kong: Hong Kong University Press.

Leveau, Remy. 1997. "The Political Culture of the Beurs" in Islam in Europe. Eds. Steven Vertovec and Ceri Peach. New York, NY: St. Martin's Press.

Levi-Strauss, Claude. 1963. Structural Anthropology. New York: Basic Books.

Lewis, Bernard. 1988. The Political Language. Chicago and London: The University of Chicago Press.

Lijphart, Arend. 1968. The Politics of Accomodation: Pluralism and Democracy in the Netherlands. Berkeley: University of California Press.

Lijphart, Arend. 1985. "Non-Majoritarian Democracy: A Comparison of Federal and Consociational Theories," Publius, 15 (2), 3-15.

Little, David. 1991. Ukraine: The Legacy of Intolerance. Washington, DC: United States Institute of Peace Press.

Manco, Ural. 2004. Turks in Western Europe (www.flwi.ugent.be/cie/umanco/umanco3.htm), 10/30/2004.

Marshall, T.H. 1963. "Citizenship and Social Class," in Sociology at the Crossroads. London: Heinemann.

Marshall, Barbara. 2000. Europe in Change: The New Germany and Migration in Europe. Manchester; New York: Manchester University Press.

Marty, Martin E., and R. Scott Appleby, eds. 1991. Fundamentalisms Observed. Vol. 1 of The Fundamentalism Project. Chicago: University of Chicago Press. 
Marty, Martin E., and R. Scott Appleby, eds. 1995. Fundamentalisms Comprehended. Vol. 4 of The Fundamentalism Project. Chicago: University of Chicago Press.

Mihara, Reiko. 2004. "the Significance and Challenges of Islamic Schools in the Netherlands: Religious Ethics and Educational Content as Forums for Learning and Growth," International Education, Japan International Education Society, 10, 46-70, translated by Reiko Mihara.

Milli Gorus-Germany- website, www.igmg.de.

Milli Gorus- The Netherlands- website, www.milligorus.nl.

Milli Gorus-The Netherlands- Women's Federation Website, www.mgvf.nl.

Moch, Leslie Page. Moving Europeans: Migration in Western Europe since 1650. Indiana: Indiana University Press.

Mohr, Irka-Christian. 2002. "Islamic Instruction in Germany and Austria: A Comparison of Principles Derived From Religious Thought," Paper written for CEMOTI (Cahiers Studies on the Eastern Mediterranean and the Turkish-Iranian World), 33.

Mol, Hans. 1976. Identity and the Sacred: A Sketch for a New Social-Scientific Theory of Religion. Oxford: Basil Blackwell.

Myrdal, Gunnar. 1944. The American Dilemma. New York: Harper Brothers.

Ozcan, Veysel. 2004. Turks in Germany: Aspects of Their Socio-Economic and SocioCultural Integration, Paper prepared for the Conference "Integration of Immigrants from Turkey in Austria, Germany and Holland”, Bogazici University, Istanbul, 27-28 February 2004.

Park, R. E. 1926. “Behind Our Masks”, Survey Graphics, 56, 135-39.

Parsons, Talcott. 1964. "Christianity and Modern Industrial Society.” In Louis Schneider, eds. Religion, Culture and Society. New York: Wiley.

Pedersen, Lars. 1999. Newer Islamic Movements in Western Europe. Brookfield: Vermont: Ashgate Publishing Company.

Pipes, Daniel. 1995. "Political Islam Is a Threat to the West." In Islam: Opposing Viewpoints, ed. Paul A. Winters. San Diego: Greenhaven Press.

Pipes, Daniel. 2000. “Islam and Islamism.” In The National Interest (Spring). 
Piscatori, James P. 1981. "The Formation of the Saudi Identity: A Case Study of the Utility of Transnationalism." In John F. Stack, eds. Ethnic Identities in a Transnational World. Westport, Connecticut: Greenwood Press.

Piscatori, James, Dale F. Eickelman. 1996. Muslim Politics. Princeton, N.J.: Princeton University Press.

Plantinga, Richard J. 1989. "W.B. Kristensen and the Study of Religion," Numen, 36 (2), December, 173-188.

Pope, Liston. 1942. Millhands and Preachers. New Haven, Conn.: Yale University Press.

Rath, John. 1983. "Political Participation of Ethnic Minorities in the Netherlands," International Migration Review, vol. 17, no.3, Autumn.

Roy, Olivier. 2003. “EuroIslam:The Jihad Within?” in The National Affairs (Spring).

Said, Edward. 1981. Covering Islam: How the Media and the Experts Determine How We See the Rest of the World. London: Routledge and Kegan Paul.

Sartre, J.P. 1943. Being and Nothingness: An Essay on Phenomenological Ontology. New York: Philosophical Library.

Savage, Timothy M. 2004. "Europe and Islam: Crescent Waxing, Cultures Clashing." In The Washington Quarterly (Summer).

Sayyid, S. 2003. A Fundamental Fear: Eurocentrism and the Emergence of Islamism. London: Zed Books Ltd.

Schiffauer, Werner. 1997. "Islamic Vision and Social Reality: The Political Culture of Sunni Muslims in Germany." In Islam in Europe, eds. Steven Vertovec and Ceri Peach. New York, NY: St. Martin's Press.

Sen, Faruk. 2004. "Turkish Diaspora in Germany" in Magazine for Development and Cooperation, October.

Seul, Jeffrey. 1999. "Ours is the Way of God': Religion, Identity, And Intergroup Conflict," Journal of Peace Research, 36 (5) September, 553-569.

Shadid, W. 1991. "The Integration of Muslim Minorities in the Netherlands". International Migration Review, 25, 355-375.

Shadid, W., P.S. van Koningsveld. 1991. "Blaming the System or Blaming the Victim? Structural Barriers Facing Muslims in Western Europe" in W. Shadid and P.S. van 
Koningsveld eds. The Integration of Islam and Hinduism in Western Europe. Kampen, the Netherlands: Kok Pharos.

Sharot, Stephen. 1974. "Minority Situation and Religious Acculturation," Comparative Studies in Society and History, 16(3) June, 329-54.

Sidahmed, Abdel Salam\& Anoushiravan Ehteshami. 1996. Islamic Fundamentalism. Colorado: Westview Press.

Skocpol, Theda. 1982. "Reniter State and Shia Islam in the Iranian Revolution", Theory and Society, 2 (2), 265-283.

Slootman, Marieke and Jean Tillie. 2006. "Processes of Radicalization: Why Some Amsterdam Muslims Become Radicals", Report Prepared for the Institute for Migration and Ethnic Studies.

Solle, Dorothee. 1984. "The Christian-Marxist Debate of the 1960s." Monthly Review 36, July-August, 20-26.

Spencer, Claire. 1996. "The Roots and Future of Islamism in Algeria" In Abdel Salam Sidahmed \& Anoushiravan Ehteshami, eds. Islamic Fundamentalism. Colorado: Westview Press.

Stack, Jr., John F. 1986. "Ethnic Mobilization in World Politics: The Primordial Perspective." In John F. Stack, Jr., eds. The Primordial Challenge: Ethnicity in the Contemporary World. New York: Greenwood Press.

Stark, Rodney and Lynne Roberts. 1996. Contemporary Social Research Methods. Bellevue: Micro Case Corporation.

Stark, Rodney, and William Sims Bainbridge. 1985. The Future of Religion. Berkeley and Los Angeles: University of California Press.

Sturm J., L. Groenendijk, B. Kruithof, and J. Rens. 1998. "Educational Pluralism: A Historical Study of So-Called Pillarization in the Netherlands,", Comparative Education, 34 (3), 281-297.

Takle, Marianne. 2007. "EU Citizens: Challenging the Notion of German National Political Community, 1990- 2005" in International Journal of the Sociology of Law, 35 (4), December, 178-191.

Tetreault, Mary Ann 1996. "Deconstructing the Other: Teaching Politics of the Middle East." PS: Political Science and Politics 29 (4). 
Tibi, Bassam. 2006. "Europeanizing Islam or the Islamization of Europe: Political Democracy vs. Cultural Difference" in Timothy A. Byrnes and Peter J. Katzenstein, eds. Religion in an Expanding Europe. Cambridge, UK; New York: Cambridge University Press.

Thranhardt, Dietrich. 1999. "Germany's Immigration Policies and Politics," in Grete Brochman, Tomas Hammar, eds. Mechanisms of Immigration Control: A Comparative Analysis of European Regulation Policies. Oxford, Berg.

The law adopted by the Romanian Parliament, www.hurriyetim.org, November 25, 2004.

Thompson, Stephen. 1974. "Survival of Ethnicity in the Japanese Community of Lima, Peru” Urban Anthropology, 3 (2), 243-61.

Tonca, Ayhan. 2004. "Associational Life of Turkish Immigrants and Whether This Life Helps or Aggravates Integration to Host and Accessibility of Dutch Institutions to Turks", Paper presented at the workshop on integration of immigrants from Turkey in Austria, Germany and the Netherlands, Bogazici University, Istanbul, February 27-28, 2004.

Todorov, Tzvetan. 1984. The Conquest of America: The Question of the Other. New York: Harper and Row.

Troeltsch, Ernst. 1981. The Social Teaching of the Christian Churches. Chicago: University of California Press.

Turner, Frederick. 1995. "Reassessing Political Culture" in Peter H. Smith, eds. Latin America in Comparative Perspective: New Approaches to Methods and Analysis. Boulder: Westview Press.

Waardenburg, Jacques. 1985. "Islam as a Vehicle of Protest." In Ernest Gellner, eds. Islamic Dilemmas. New York, Berlin and Amsterdam: Mouton Publishers.

Wagley, Charles, and Marvin Harris. 1968. Minorities in the New World. New York: Columbia University Press.

Weiner , Myron. 1987. "Introduction." In Understanding Political Development, ed. Myron Weiner and Samuel Huntington. Boston: Little, Brown and Company.

White, Jenny B. 1997. "Turks in the New Germany," American Anthropologist 99 (4) 754-69.

Wiktorowicz, Quintan. 2004. "Introduction: Islamic Activism and Social Movement Theory." In Quintan Wiktorowicz, eds. Islamic Activism. Indianapolis: Indiana University Press. 
Wilson, Bryan. 1982. Religion in Sociological Perspective. New York: Oxford University Press.

Wong, Bernard. 1978. "A Comparative Study of the assimilation of the Chinese in New York City and Lima, Peru", Comparative Studies in Society and History, vol. 20, no.3 (July).

World Values Survey, www.worldvaluessurvey.org.

Yuan, D. Y. 1963. "Voluntary Segregation: A Study of New Chinatown," Phylon, XXIV (3), 225-68.

Zelditch, M., Jr. 1969. "Can You Really Study an Army in the Labaratory?” in A. Etzioni, eds. A Sociological Reader on Complex Organizations. New York: Holt Rinehart and Winston.

Zeleza, P.T. “The Post-colonial Uprising in France,” European Affairs, November 16.

Zizek, Slavoj. 1989. The Sublime Object of Ideology. London; New York: Verso. 


\section{APPENDIX 1}

\section{SURVEY IN TURKISH}

Cinsiyetiniz:

( ) Kadın ( ) Erkek

Yaşınız:......

Hangi ülkede yaşıorsunuz?

Kendinizi aşağıdaki cemaatlerden hangisine yakın hissediyorsunuz?

( ) Milli Görüş ～( ) Diyanet İşleri Türk İslam Birliği （ ) İslam Kültür Merkezleri

Aşağıdaki aktiviteleri ne sıklıkta yapıyorsunuz? Her gün mü, haftada bir kaç kez mi, ayda bir kaç kez mi, hiç mi?

A1. Camiden arkadaşlarınızla vakit geçirmek

( ) Her gün vakit geçiriyorum

( ) Haftada bir kaç kez vakit geçiriyorum

( ) Ayda bir kaç kez vakit geçiriyorum

( ) Yılda bir kaç kez vakit geçiriyorum

( ) Hiç vakit geçirmiyorum

A2. Türk ailelerle ve Türk arkadaşlarla vakit geçirmek

( ) Her gün vakit geçiriyorum

( ) Haftada bir kaç kez vakit geçiriyorum

( ) Ayda bir kaç kez vakit geçiriyorum

( ) Yılda bir kaç kez vakit geçiriyorum

( ) Hiç vakit geçirmiyorum

A3. Hollanda'll/ Alman ailelerle ve arkadaşlarla vakit geçirmek

( ) Her gün vakit geçiriyorum

( ) Haftada bir kaç kez vakit geçiriyorum

( ) Ayda bir kaç kez vakit geçiriyorum

( ) Yılda bir kaç kez vakit geçiriyorum

( ) Hiç vakit geçirmiyorum

A4. Kendinizi Hollanda'l1/Alman gibi hissediyor musunuz? 
( ) Tamamen Hollanda'l1/Alman gibi hissediyorum

( ) Kismen Hollanda'11/Alman gibi hissediyorum

( ) Hiç Hollanda'l1/Alman gibi hissetmiyorum

A5. Hollanda/Alman toplumunun bir parçası olduğunuzu hissediyor musunuz?

( ) Tamamen bir parçası gibi hissediyorum

( ) Kısmen bir parçası gibi hissediyorum

( ) Hiç hissetmiyorum

A6. Haklarınızın ve çıkarlarınızın Hollanda/Alman hükümeti ve sivil kurumları tarafindan temsil edilip korunduğuna inanıyor musunuz?

( ) Tamamen temsil edilip korunduğuna inanıyorum

( ) Kısmen temsil edilip korunduğuna inanıyorum

( ) Hiç temsil edilip korunmadığını düşünüyorum

A7. Aşağıdakilerden en çok hangisine ait hissediyorsunuz kendinizi? İkinci olarak hangisini seçerdiniz? Lütfen birinci tercihinizin yanına 1, ikincisinin yanına 2 yazınız.

( ) Yaşadığım şehir

( ) Hollanda/Almanya

( ) Avrupa

( ) Türkiye

( ) Dünya

( ) İslam alemi

A8. Hollandaca/Almanca konuşuyor musunuz?

( ) Akıcı olarak ( Bir Hollanda'lı/Alman ile hiç bir zorluk çekmeden her konuda sohbet edebilirim)

( ) Biraz (Günlük işlerimi halledecek kadar)

( ) Hollandaca/Almanca bilmiyorum

A9. Eğitiminizi Türkiye'de mi Hollanda/Almanya'da mı tamamladınız?
( ) Türkiye
( ) Hollanda/Almanya
( ) Eğitim almadım

A10. 9. soruya cevabınız Türkiye ise aşağıdakilerden hangisi sizin için doğrudur?

( ) İlkokuldan terk

( ) İlkokul mezunuyum

( ) Ortaokuldan terk

( ) Ortaokul mezunuyum 
( ) Liseden terk

( ) Lise mezunuyum

( ) Üniversiteden terk

( ) Üniversite mezunuyum

( ) Yüksek lisansımı tamamladım

A11. 9. soruya cevabiniz Hollanda/Almanya ise eğitim durumunuzu yazar mısınız?

Aşağıdaki aktiviteleri ne sıklıkta yapıyorsunuz? Her gün/neredeyse her gün mü, haftada bir kaç kez mi, ayda bir kaç kez mi, hiç mi?

A12. Türk televizyon kanallarını izlemek

( ) Her gün/neredeyse her gün

( ) Haftada bir kaç kez

( ) Ayda bir kaç kez

( ) Hiç izlemiyorum

A13. Hollanda/Alman kanallarında haberleri izlemek

( ) Her gün/neredeyse her gün

( ) Haftada bir kaç kez

( ) Ayda bir kaç kez

( ) Hiç izlemiyorum

A14. Türkçe gazeteleri okumak

( ) Her gün/neredeyse her gün

( ) Haftada bir kaç kez

( ) Ayda bir kaç kez

( ) Hiç okumuyorum

A15. Hollanda/Alman gazetelerini okumak

( ) Her gün/neredeyse her gün

( ) Haftada bir kaç kez

( ) Ayda bir kaç kez

( ) Hiç okumuyorum

Simdi size 10 puanli bir cetvel gosterecegim. Siz, hanenizin maddi durumunu ke kadar tamin edici buluyorsunuz? Eger hanenizin maddi durumunu hic tatminkar bulmuyorsaniz 1, fevkalade tatminkar buluyorsaniz 10 olmak uzere, kendi durumunuza bir puan veriniz. 


\begin{tabular}{|llllllllll|}
\hline 1 & 2 & 3 & 4 & 5 & 6 & 7 & 8 & 9 & 10 \\
\hline
\end{tabular}

Hiç Fevkalade

tatminkar tatminkar

değil
A17. Çalışıyor musunuz?
( ) Evet ( ) Hayır ( ) Emekliyim
A18. Calışıyorsanız aşağıdakilerden hangi kategoridesiniz?
( ) İşçi
( ) Memur, büro çalışanı, ofis çalışanı
( ) Devlet memuru
( ) Serbest meslek sahibi

A19. Hollanda/Almanya vatandaşı mısınız?

( ) Evet ( ) Hayır

A20. Hollanda/Almanya politikasını medyadan ne s1klıkta takip ediyorsunuz?

( ) Her gün

( ) Haftada iki üç kere

( ) Haftada bir kere

( ) Daha az

( ) Takip etmiyorum

A21. Türkiye politikasini ve gündemini ne s1kl1kta takip ediyorsunuz?
( ) Her gün
( ) Haftada iki üç kere
( ) Haftada bir kere
( ) Daha az
( ) Takip etmiyorum

A22. Şimdi size iki fikir okuyacağım. Hangisi sizin görüşlerinize daha yakın? 
( ) İyi insan ilişkileri kurabilmek için diğer insanların tercihlerini bilmek ve anlamak önemlidir.

( ) İyi insan ilişkileri kurabilmek için insanın kendi tercihlerini açıkça belirtmesi önemlidir.

Aşağıdakilerden hangisinin komşunuz olmasını İSTEMEZDİNIZZ?

A23. Suç işlemekten hüküm giymiş/sabıkalı insanlar

İsterim İstemem

A24. Hollandalilar/Almanlar

A25. Alkol bağımlıları

A26. Duygusal olarak dengesiz insanlar

A27. Hristiyanlar

A28. AIDS'li insanlar

A29. Hap/uyuşturucu madde bağımlıları

A30. Eşcinseller

A31. Yahudiler

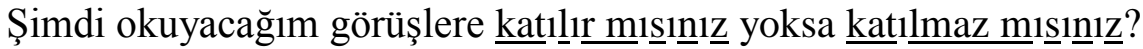

A32. Ülkede yeterince iş yoksa, çalışmak kadınlardan çok erkeklerin hakkıdır.

( ) Katılırım

( ) Katılmam

( ) Fikrim yok

Şimdi size bazı görüşler okuyacağım. Bunların her biri hakkındaki fikrinizi, "kesinlikle kabul ederim", "kabul ederim", "kabul etmem", ya da "kesinlikle kabul etmem” şeklinde belirtiniz.

\begin{tabular}{|c|c|c|c|c|}
\hline & Kesin Kabul & Kabul & Red & Kesin Red \\
\hline $\begin{array}{l}\text { A33. Genelde erkekler kadınlardan } \\
\text { daha iyi siyasi lider oluyorlar. }\end{array}$ & ....... & $\ldots$ & & \\
\hline
\end{tabular}
daha çok erkek çocuk için önemlidir.

A35. Sizce Avrupa'daki Türk gençliğinin önündeki en önemli tehlike aşağıdakilerden hangisidir?

( ) Batılı fikirleri ve yaşam tarzlarını benimsemeleri

( ) Artan işsizlik

( ) Türkiye ile bağlarını kaybetmeleri 
A36. İçinde yaşadığımız toplumla ilgili üç temel görüş okuyacağım. Lütfen sizin görüşünüze en uygun olanını seçiniz.

( ) Tüm toplum düzeni büyük bir kökten ve devrimci değişimle yeniden şekillendirilmelidir.

( ) Toplumumuz yapılacak reformlarla yavaş yavaş ıslah edilmeli, iyileştirilmelidir.

( ) Bugünkü toplum düzenimiz her türlü değişiklik girişimine karşı korunmalıdır.

İnsanların demokratik yönetim biçimleriyle ilgili olarak ileri sürdüğü bazi görüşler okuyacağım. Bu görüşlerin her biri için "kesinlikle katılırım", "katılırım", "katılmam" veya "kesinlikle katılmam" şeklinde fikrinizi belirtiniz.

Kesinlikle Katılırım Katılmam $\begin{gathered}\text { Kesinlikle } \\ \text { katılırım }\end{gathered}$
katımam

A37. Demokrasilerde ekonomi kötü isler.

A38. Demokrasilerde kararsizlik fazla

olur.

A39. Demokrasiler kamu düzenini sağlamakta başarılı olamaz.

A40. Demokrasinin problemleri olabilir ama her türlü yönetim biçiminden daha iyidir.

Şimdi size bazı siyasal sistemler sayacağım ve her birinin bir ülkeyi yönetmek açısından ne kadar iyi olduğunu soracağım. Her biri için "ç̧ok iyi”, "iyi”, "kötü" veya "çok kötü" şeklinde fikrinizi belirtiniz.

\section{Çok iyi İyi Kötü Çok kötü}

A41. Parlementoyla seçimlerle uğraşmak zorunda kalmayan güçlü bir lidere sahip olmak A42. Hükümet yerine uzmanların ülke için en iyi olduğuna inandıklari şeyleri yapmaları A43. Ordunun yönetmesi

A44. Demokratik bir siyasal sistemle yönetim

Şimdi size bazı görüşler okuyacağım. Bu görüşlerin her biri için "kesinlikle katılırım", "katılırım", "katılmam" veya "kesinlikle katılmam" şeklinde fikrinizi belirtiniz. 


\section{Kesinlikle Kat1lırım Katılmam Kesinlikle}

katılırım katılmam

A45. Allah'a inanmayan politikacılar toplum hizmeti üstlenmemeli

A46. Dini liderler insanlarin seçimlerde kime oy verdiklerini etkilememeli

A47. Dini inancı kuvvetli daha fazla insan görev başına gelse Türkiye için daha iyi olurdu.

A48. Dini liderler hükümet kararlarını etkilememeli.

Aşağıdaki görüşe katılıyor musunuz? Fikrinizi "kesinlikle katılırım", "katılırım", "katılmam", "kesinlikle katılmam" şeklinde belirtiniz.

\section{Kesinlikle Katılırım Katılmam Kesinlikle katılırım katılmam}

A49. Kur'an'1 yorumlarken bugünün şartlarını göz önüne almalıyız.

A50. Nasıl bir toplumda yaşamak isterdiniz?

( ) Her dinin ve kültürün eşit temsil edildiği ve ifade hakkı olduğu çok dinli ve çok kültürlü bir toplumda

( ) İslam'ın egemen olduğu homojen bir toplumda.

A51. Sizce aşağıdakilerden hangisi çocuklarınızı yetiştirmek icin ideal bir ortam?

( ) Çocuklarımın farklı dinlerden ve kültürden insanlarla kaynaşıp tanışabileceği çok dinli ve çok kültürlü bir toplum.

( ) Çocuklarımın diğer Türk çocuklarla olabileceği bir Türk mahallesi 


\section{APPENDIX 2}

\section{SURVEY IN ENGLISH}

Gender:

( ) Female ( ) Male

Age: .......

Country of Residence:

Which of the Islamist communities would you identify yourself with?

\section{( ) Milli Gorus ( ) Diyanet ( ) Islam Cultural Center}

I am going to ask how often you do various things. For each activity, would you say you do them every day or almost every day, once or twice a week, only a few times a month, only a few times a year or not at all?

A1. Spend time with your friends from the mosque.

( ) Everyday/almost everyday

( ) Once or twice a week

( ) Few times a month

( ) Few times a year

( ) Not at all

A2. Spend time with Turkish friends and families.

( ) Everyday/almost everyday

( ) Once or twice a week

( ) Few times a month

( ) Few times a year

( ) Not at all

A3. Spend time with Dutch/German friends and families.

( ) Everyday/almost everyday

( ) Once or twice a week

( ) Few times a month

( ) Few times a year

( ) Not at all 
A4. Do you feel like Dutch/German?

( ) Totally/mainly

( ) Partially

( ) Hardly/not at all

A5. Do you feel that you are part of the Dutch/German society?

( ) Totally/mainly

( ) Partially

( ) Hardly/not at all

A6. Do you believe that your rights and interests are being protected/represented by the Dutch/German governmental and civil institutions?

( ) Totally/mainly

( ) Partially

( ) Hardly/not at all

A7. To which of these geographical groups would you say you belong first of all? And the next?

( ) Locality or town where you live

( ) The Netherlands/Germany

( ) Europe

( ) Turkey

( ) The world as a whole

( ) The Islamic world

A8. Do you speak German/Dutch?

( ) Fluently (I can have a conversation with a German/Dutch without any difficulty)

( ) Very little (I cannot have a conversation but I can manage to find my way if I am lost)

( ) Not at all

A9. Did you get your education in Turkey or in Germany/the Netherlands?

( ) Turkey ( ) The Netherlands/Germany ( ) No formal education

A10. If your answer to question A9 is Turkey, what is the highest educational level that you have attained?

( ) Incomplete primary school

( ) Complete primary school

( ) Incomplete secondary school: technical/vocational type

( ) Complete secondary school: technical/vocational type 
( ) Incomplete secondary school: university-preparatory type

( ) Complete secondary school: university-preparatory type

( ) Some university level education, without degree

( ) University level education, with degree

( ) Graduate degree

A11. If your answer to question A9 is Germany/the Netherlands, please state the highest educational level that you have attained.

I am going to ask how often you do various things. For each activity, would you say you do them every day or almost every day, once or twice a week, only a few times a month, or not at all?
A12. Watch Turkish TV channels
( ) Everyday/almost everyday
( ) once or twice a week
( ) Few times a month
( ) Not at all
( ) Everyday/almost everyday
( ) once or twice a week
( ) Few times a month
( ) Not at all

A13. Watch news on German/Dutch channels
A14. Read Turkish newspapers
( ) Everyday/almost everyday
( ) once or twice a week
( ) Few times a month
( ) Not at all
A15. Read German/Dutch newspapers
( ) Everyday/almost everyday
( ) once or twice a week
( ) Few times a month
( ) Not at all

A16. I will show you a 10 point scale. Please rate your income on the scale, 1 being not satisfactory at all, 10 being quite satisfactory. 


\begin{tabular}{|llllllllll|}
\hline 1 & 2 & 3 & 4 & 5 & 6 & 7 & 8 & 9 & 10 \\
\hline $\begin{array}{l}\text { Not } \\
\text { satisfactory }\end{array}$ & & & & & & & & $\begin{array}{l}\text { Quite } \\
\text { satisfactory }\end{array}$ \\
at all & & & & & & & & &
\end{tabular}

at all

A17. Are you employed?

( ) Yes ( ) No ( ) Retired

A18. If yes, what kind of occupational position do you have?

( ) Blue collar worker

( ) White collar worker

( ) Self-employed

( ) Civil servant

A19. Are you a German/Dutch citizen?

( ) Yes ( ) No

A20. How often do you follow German/Dutch politics in the news on TV or on the radio or in the daily newspapers?
( ) Everyday
( ) Several times a week
( ) Once a week
( ) Less often
( ) Never

A21. How often do you follow Turkish politics in the news on TV or on the radio or in the daily newspapers?
( ) Everyday
( ) Several times a week
( ) Once a week
( ) Less often
( ) Never

A22. For each of the following pairs of statements, please tell me which one comes closest to your own views. 
( ) To build good human relationships, it is most important to try to understand others preferences

( ) To build good relationships, it is most important to express one's own preferences clearly.

On this list are various groups of people. Could you please sort out any that you would not like to have as neighbours?

A23. People with a criminal record

A24. Germans/Dutch

A25. Heavy drinkers

A26. Emotionally unstable people

A27. Christians

A28. People who have AIDS

A29. Drug addicts

A30. Homosexuals

A31. Jews

Do you agree or disagree with the following statement?

A32. Men jobs are scarce, men should have more right to a job than women.

( ) Agree ( ) Neither agree nor disagree ( ) Disagree

For each of the following statements I read out, can you tell me how much you agree with each. Do you agree strongly, agree, disagree or disagree strongly?

A33. On the whole, men make better political leaders than women do.

( ) Strongly agree ( ) Agree ( ) Disagree ( ) Strongly disagree

A34. A university education is more important for a boy than a girl.

( ) Strongly agree ( ) Agree ( ) Disagree ( ) Strongly disagree

A35. What do you think the biggest dander Turkish youth is facing in Europe?

( ) Rising unemployment

( ) Losing of their ties to Turkey

( ) Adopting Western ideas and lifestyles 
A36. On this card are three basic kinds of attitudes concerning the society we live in. Please choose the one which best describes your own opinion.

( ) The entire way our society is organized must be radically changed by revolutionary action.

( ) Our society must be gradually improved by reforms.

( ) Our present society must be valiantly defended against all subversive forces.

I am going to read off some things that people sometimes say about a democratic system. Could you please tell me if you agree strongly, agree, disagree, or disagree strongly, after I read each one of them?

$\begin{array}{lll}\begin{array}{l}\text { Strongly } \\ \text { agree }\end{array} & \text { Agree Disagree } & \begin{array}{l}\text { Strongly } \\ \text { disagree }\end{array}\end{array}$

A37. In democracy, the economic system runs badly.

A38. Democracies are indecisive.

A39. Democracies aren't good at maintaining order.

A40. Democracy may have problems, but it's better than any other form of government.

I am going to describe various types of political systems and ask what you think about each as a way of governing your country. For each one, would you say, it is a very good, fairly good, bad or very bad way of governing your country?

A41. Having a strong leader who

Very Fairly Bad Fairly

Good Good Bad
and elections.

A42. Having experts, not government, make decisions according to what they think is the best for the country

A43. Having the army rule

A44. Having a democratic political system 
How much do you agree or disagree with each of the following?

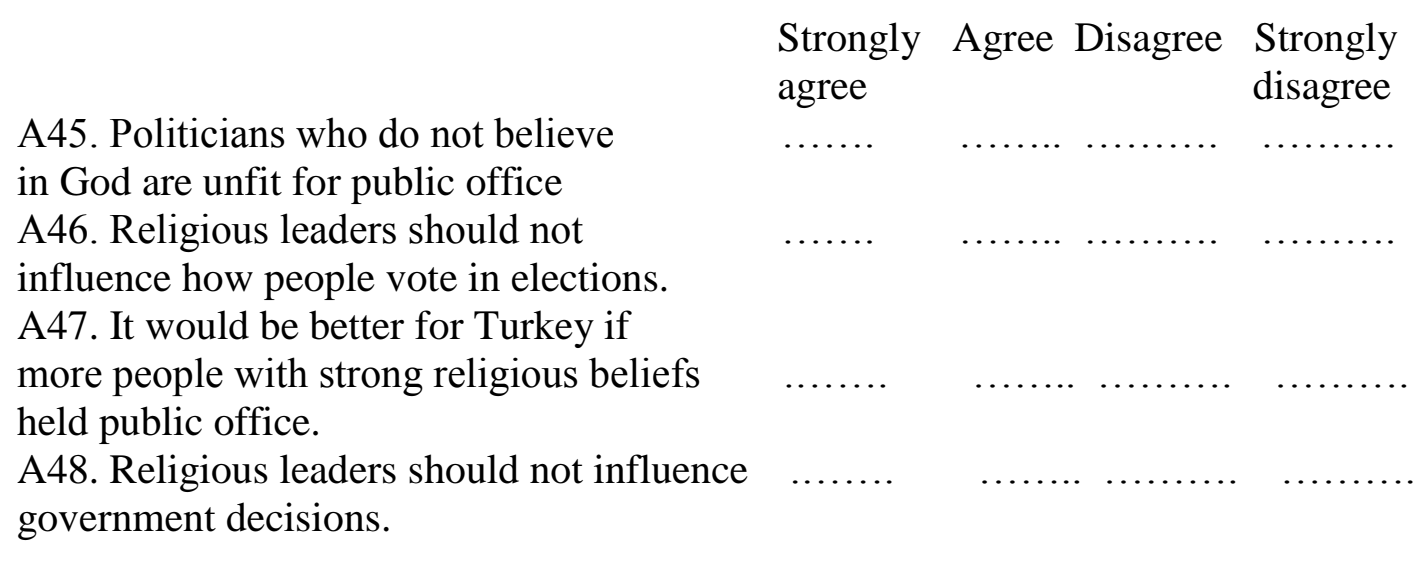

Do you agree, strongly agree, disagree or strongly disagree with the following statement?

$\begin{aligned} & \text { Strongly } \\ & \text { agree }\end{aligned}$
Agree Disagree $\begin{aligned} & \text { Strongly } \\ & \text { disagree }\end{aligned}$

A49. While interpreting Quran, one should take today's circumstances into consideration.

A50. What type of society would you like to live in?

( ) In a multi-cultural and multi-religious society where every culture and religion has equal rights and representation.

( ) In a homogeneous society where Islam is the dominant religion.

A52. Which one do you think is the best environment to raise your children?

( ) A racially and religiously mixed neighborhood where my child can have interaction with people from different religions and cultures.

( ) In a Turkish neighborhood where my child can interact with other Turks. 
VITA

\section{GÖNÜL TOL}

$1996-2001$

B.A., International Relations, Middle East

Technical University (METU), Ankara, Turkey.

2001-2002

M.A., Political Science, Florida International

University, Miami, Florida.

2001-2007

Teaching Assistant, Political Science, Florida

International University, Miami, Florida

\section{PAPERS AND PRESENTATIONS}

"The Rise of Islamism among Turkish Immigrants as a Response to Social Marginalization: The Case of Germany and the Netherlands", Roundtable organized by Friedrich Ebert Foundation and TUSIAD-US, Washington, DC, April 24, 2008.

"Institutionalization of Islam in Europe: Beyond EU Jurisdiction", Diversity and European Integration Conference organized by the Miami-Florida European Union Center of Excellence, Miami, Florida, April 2-3, 2008.

"Are There Revolutionary Religions or Do They Become Revolutionary? A Comparative Analysis of Shiism Before and After the Shah Regime", International Studies Association, San Francisco, CA, March 26-29, 2008.

"A Comparative Study of the Integration of the Turks in Germany and the Netherlands", International Studies Association, Honolulu, Hawaii, March 01-05, 2005.

"Population Dispersion and Ethnic Consciousness: The Turkish Case", International Studies Association-Midwest, St. Louis, Missouri, November 5-6, 2004.

"Population Dispersion and Ethnic Mobilization: The Case of the Roma" (with Dr. Rebecca Mae Salokar), International Studies Association, Montreal, Quebec, Canada, March 17-20, 2004.

"Closing the Doors: Far Right Parties and Immigration in Western Europe" with Dr. Paul Mullen, Annual Meeting of the International Studies Association, Portland, Oregon, February 2003.

"Beyond Systemic Approaches: The Study of Irredentism", International Studies Association-West, Las Vegas, Nevada, October 10-11, 2003. 
"Defining a Role for the United Nations in Iraq", European International Relations Summer School: New Approaches to Conflict, Canterbury, UK, July 13-26, 2003.

\section{AWARDS AND RESEARCH GRANTS}

International Studies Association Travel Grant, 2007

Florida International University Department of Political Science Summer Research Grant, 2007

Miami-Florida European Union Center Graduate Research Award recipient, 2005.

Travel Grant, Jack D. Gordon Institute for Public Policy and Citizenship Studies, Summer 2005.

Travel Grant, Graduate Student Association at Florida International University, November 2004.

Travel Grant, Graduate Student Association at Florida International University, March 2004.

Travel Grant, Jack D. Gordon Institute for Public Policy and Citizenship Studies, March 2004.

Graduate Student Association Scholarly Forum Winner, the Third Best Paper in Social Sciences, 2004.

Travel Grant, Graduate Student Association at Florida International University, October 2003.

Research Grant, Jack. D. Gordon Institute for Public Policy and Citizenship Studies for participating in European Consortium for Political Research at University of Kent at Canterbury, UK, Summer 2003.

Howard Penniman/Pi Sigma Alpha Graduate Scholarship Winner, 2003. 